International Scientific Association

Open European Academy of Public Sciences (OEAPS Inc.)

\title{
Social Sciences: Achievements and Prospects Journal
}

No. 4(12), 2019

Barcelona, Spain

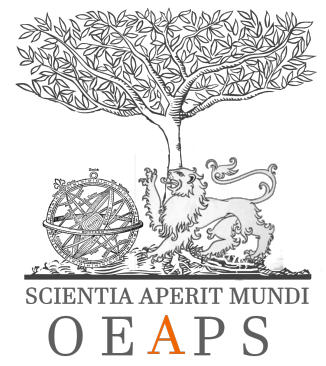




\section{Social Sciences: Achievements and Prospects Journal 4(12), 2019}

C 2019 The Author. Published by ISA \& OEAPS EU Inc. This is an open access article under the CC BYNC-ND license (http://creativecommons.org/licenses/by-nc-nd/4.0/). 
OEAPS is am inprint of ISA \& OEAPS INC.

Gran Via de les Corts Catalanes, 585, 08007 Barcelona, SP

Unter den Linden, 4, 10099 Berlin, DE

Goloseevsky Ave, 3, 03039, Kiev, UK

267/347 Pratamnuk, Soi 2, Moo 12, Banglamung, Chonburi, 20150, THA

Copyright $(C 2018$ ISA \& OEAPS Inc. All rights reserved.

This journal and the individual contributions contained in it are protected under copyright by Open European Academy of Public Sciences, and the following terms and conditions apply to their use:

Photocopying

Single photocopies of single articles may be made for personal use as allowed by national copyright laws. Permission of the Publisher and payment of a fee is required for all other photocopying, including multiple or systematic copying, copying for advertising or promotional purposes, resale, and all forms of document delivery. Special rates are available for educational institutions that wish to make photocopies for non-profi t educational classroom use. For information on how to seek permission visit https://academy.scopuseu.com/

Derivative Works

Subscribers may reproduce tables of contents or prepare lists of articles including abstracts for internal circulation within their institutions. Permission of the Publisher is required for resale or distribution outside the institution. Permission of the Publisher is required for all other derivative works, including compilations and translations (please consult https://academy.scopuseu.com/).

\section{Electronic Storage or Usage}

Permission of the Publisher is required to store or use electronically any material contained in this journal, including any article or part of an article (please consult https://academy.scopuseu.com/).

Except as outlined above, no part of this publication may be reproduced, stored in a retrieval system or transmitted in any form or by any means, electronic, mechanical, photocopying, recording or otherwise, without prior written permission of the Publisher.

Notice

No responsibility is assumed by the Publisher for any injury and/or damage to persons or property as a matter of products liability, negligence or otherwise, or from any use or operation of any methods, products, instructions or ideas contained in the material herein. Because of rapid advances in the medical sciences, in particular, independent verifi cation of diagnoses and drug dosages should be made. Although all advertising material is expected to conform to ethical (medical) standards, inclusion in this publication does not constitute a guarantee or endorsement of the quality or value of such product or of the claims made of it by its manufacturer.

Funding bodv agreements and policies

OEAPS Inc. has established agreements and developed policies to allow authors whose articles appear in journals published by ISA\&OEAPS Inc., to comply with potential manuscript archiving requirements as specifi ed as conditions of their grant awards. To learn more about existing agreements and policies please visit https://academy.scopuseu.com/

Publication information: «Social Sciences: Achievements and Prospects Journal» 4(12), 2019. (ISBN: 9781070722733$).$

For 4(12), 2019, December issues is scheduled for publication. Subscription prices are available upon request from the Publisher or from the ISA\&OEAPS Inc. Customer Service Department nearest you or from this journal's website (http://scopuseu.com/scopus/index.php/ssap/index).

Further information is available on this journal and other ISA\&OEAPS Inc. products through OEAPS website (https://academy.scopuseu.com). Subscriptions are accepted on a prepaid basis only and are entered on a calendar year basis. Issues are sent by standard mail (surface within Europe, air delivery outside Europe). Priority rates are available upon request. Claims for missing issues should be made within six months of the date of dispatch. Orders, claims, and journal enquiries: Please visit our Support Hub pagehttps://academy.scopuseu.com for assistance.

Author inquiries: You can track your submitted article at https://academy.scopuseu.com. You can track your accepted article at https://academy.scopuseu.com. You are also welcome to contact Customer Support via https://academy.scopuseu.com

Advertising information: If you are interested in advertising or other commercial opportunities please e-mail: office@scopuseu.com and your enquiry will be passed to the correct person. Á who will respond to you within 48 hours. Printed in the Germany 
(C) 2019 The Author. Published by ISA \& OEAPS EU Inc. This is an open access article under the CC BY-NC-ND license (http://creativecommons.org/ licenses/by-nc-nd/4.0/). 
Social Sciences: Achievements and Prospects is a major international forum for the analysis and debate of trends and approaches in social science research. The journal provides a space for innovative theoretical as well as empirical contributions to issues that transcend the framework of the traditional disciplines. Given its international orientation, contributions of a comparative or cross-cultural nature are particularly welcome. Social Sciences: Achievements and Prospects aims to contribute to overcoming fragmentation and over-specialization in current social-science research. Comprehensive and original contributions will tend to be of a tentative nature, trying out new avenues on terrains that are far from being well known. The journal welcomes trend reports on intellectually stimulating new developments to make them more widely known and to offer a space to assess their significance in answering key questions of scholarship in our time.

There is one blind verification process in the journal. All articles will be initially evaluated by the editor for compliance with the journal. Manuscripts that are considered appropriate are then usually sent to at least two independent peer reviewers to assess the scientific quality of the article. The editor is responsible for the final decision on whether to accept or reject the article. The editor's decision is final.

The main criterion used in assessing the manuscript submitted to the journal is: uniqueness or innovation in the work from the point of view of the methodology being developed and / or its application to a problem of particular importance in the public sector or service sector and / or the setting in which the efforts, for example, in the developing region of the world. That is, the very model / methodology, application and context of problems, at least one of them must be unique and important.

Additional criteria considered in the consideration of the submitted document are its accuracy, organization / presentation (ie logical flow) and recording quality.
Chief Editor

Mark Freeman Doctor of Philosophy, Estonia

Editorial Board

Alexei N. Ivanov Candidate of Economic

Sciences, Russia

Anna Voitsek Doctor of Psychology, Poland

Arthur V. Amirov Doctor of Psychological

Sciences, Russia

Zoya N. Krasinskaya Candidate of Political

Sciences, Russia

Philip V. Dudin Doctor of Philosophy, Ukraine

Ninel A. Yatchenko Doctor of Law, Ukraine

Tatyana A. Mikhailova Ph.D. in Philosophy,

Russia

Luc Boltanski, École des Hautes Études en

Sciences Sociales (EHESS), Paris, France

Dipesh Chakrabarty, University of Chicago, USA

Jean Copans, Université Paris Descartes, France

Monique De Saint Martin, IRIS / EHESS, France

Didier Fassin, Institute for Advanced Study,

Princeton, USA

Maurice Godelier, École des Hautes Études en

Sciences Sociales (EHESS), France

Benoit Godin, Institut national de la recherche

scientifique (INRS), Canada

Dipankar Gupta, Centre for Public Affairs and

Critical Theory / Shiv Nadar University, Indial

Approved at the meeting of the editorial board Social Sciences: Achievements and Prospects Journal 4(12), 2019/ OEAPS Inc.(Open European Academy of Public Sciences); Chief Editor Mark Freeman Barcelona, Spain. 16.05.2019: OEAPS Inc., 2019. - 92 P.

Number layout 09.06.2019

Signed in print 10.06.2019

Published on 11.06.2019

10.5281/zenodo.3241979
The paper used in this publication meets the requirements of ANSI/NISO Z39.48-1992 (Permanence of Paper) 
Journals Covered by Leading Indexing Databases

Open European Academy of Public Sciences aims to have all of its journals covered by the Science Citation Index Expanded (SCIE) and Scopus and Web of Science indexing systems. Several journals have already been covered by SCIE for several years and have received official Impact Factors. Some 'life science' related journals are also covered by PubMed/MEDLINE and archived through PubMed Central (PMC). All of our journals are archived with the Spanish and Germany National Library.

All Content is Open Access and Free for Readers Journals published by Open European Academy of Public Sciences are fully open access: research articles, reviews or any other content on this platform is available to everyone free of charge. To be able to provide open access journals, we finance publication through article processing charges (APC); these are usually covered by the authors' institutes or research funding bodies. We offer access to science and the latest research to readers for free. All of our content is published in open access and distributed under a Creative Commons License, which means published articles can be freely shared and the content reused, upon proper attribution.

Open European Academy of Public Sciences Publication Ethics Statement

Open European Academy of Public Sciences is a member of the Committee on Publication Ethics (COPE). Open European Academy of Public Sciences takes the responsibility to enforce a rigorous peerreview together with strict ethical policies and standards to ensure to add high quality scientific works to the field of scholarly publication. Unfortunately, cases of plagiarism, data falsification, inappropriate authorship credit, and the like, do arise. Open European Academy of Public Sciences takes such publishing ethics issues very seriously and our editors are trained to proceed in such cases with a zero tolerance policy. To verify the originality of content submitted to our journals, we use iThenticate to check submissions against previous publications.

Mission and Values

As a pioneer of academic open access publishing, we serve the scientific community since 2009. Our aim is to foster scientific exchange in all forms, across all disciplines. In addition to being at the root of Open European Academy of Public Sciences and a key theme in our journals, we support sustainability by ensuring the longterm preservation of published papers, and the future of science through partnerships, sponsorships and awards. 


\section{Contents}

Виктория Петровна Устинова

Развитие коммуникативных умений восьмиклассников с помощью проектов на уроках обществознания

Жанна Толеуовна Балмагамбетова, Татьяна Викторовна Стеничкина

КАЗАХОЯЗЫЧНЫЕ ВКРАПЛЕНИЯ В ПУБЛИЦИСТИКЕ: КОММУНИКАТИВНОПРАГМАТИЧЕСКИЙ АСПЕКТ

Gulnar Dmitrievna Sharakpaeva, Olga Alexandrovna Manankova

DISTANCE EDUCATION IN THE CONTEXT OF GLOBALIZATION: PROBLEMS, SEARCH FOR A SOLUTION

Dina Mironovna Polyak, Zhanna Borisovna Erzhanova INTERNET-BASED PROJECT WORK

Ine's Domingo, Pilar Garcı'a-Argu“ elles, Jordi Nadal, Josep M Fullola, Jose' L. Lerma 41-64 et.al.

Humanizing European Paleolithic art: A new visual evidence of human/bird interactions at L’Hort de la Boquera site (Margalef de Montsant, Tarragona, Spain)

The Importance of Dynamics and Writing Practical Knowledge in the Study of Ancient

Khorezm History

Amir Temur and religious legal issues

Temur's rules are the most important law in establishing a just and powerful state

Problems and solutions of increasing socio-political activeness of youth 


\section{International Periodical Scientific Journals}

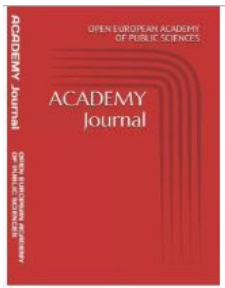

Academy Journal Applied Sciences Journal World

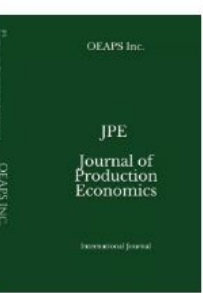

Journal of

Journal of Accounting

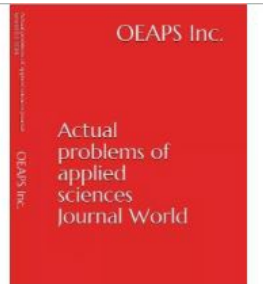

\section{Humanitarian and Socio-}

Economic Sciences Journal

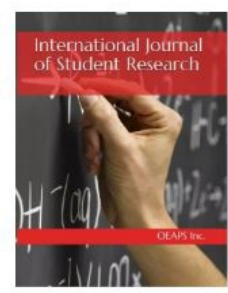

International Journal of Student Research

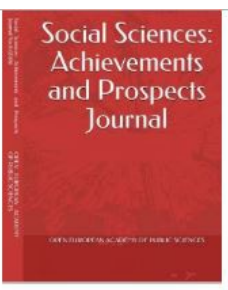

Social Sciences:

Achievements and Prospects Journal

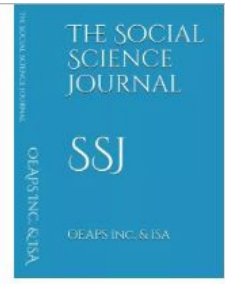

The Social Science Journal

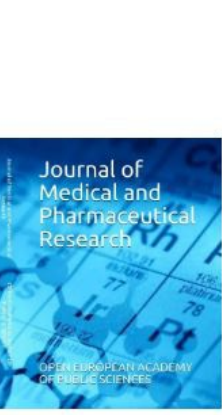

Journal of Medical and Pharmaceutical Research

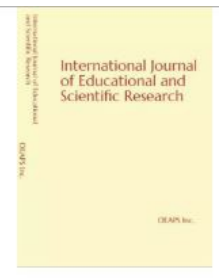

International Journal of Educational and Scientific Research

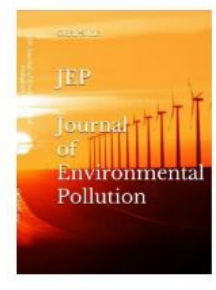

Journal of Technical and Natural Sciences
Journal of Environmental Pollution 
Social Sciences: Achievements and Prospects Journal 4(12), 2019

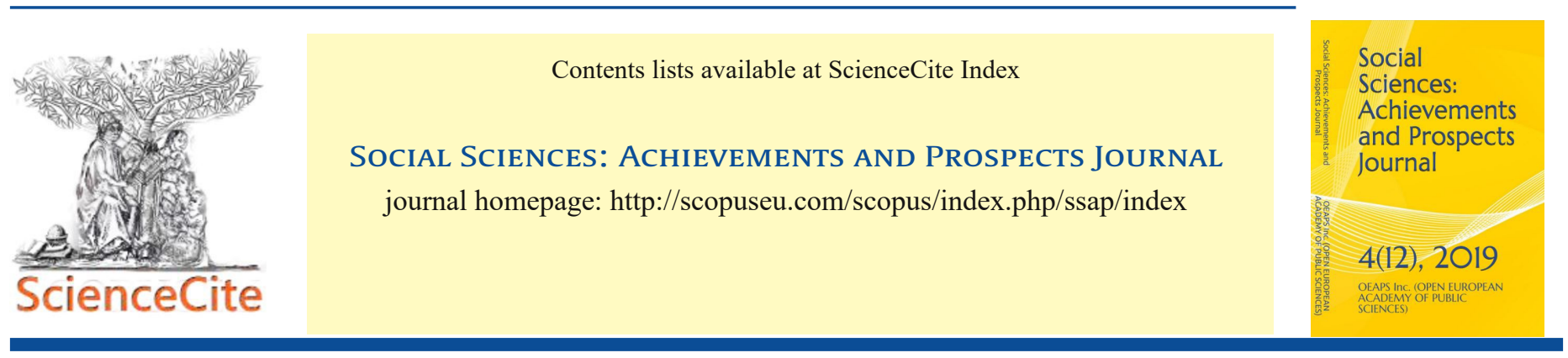

Развитие коммуникативных умений восьмиклассников с помощью проектов на уроках обществознания

\section{Устинова Виктория Петровна}

магистрант II курса обучения Исторического факультета,

Северо-Восточный федеральный университет, г. Якутск, Россия

The development of communication skills of eighth-graders with the help of projects in social studies classes

\section{Ustinova Victoria Petrovna}

II undergraduate course of study the Faculty of History, the NorthEastern Federal University, Yakutsk, Russia

\begin{tabular}{llll}
\hline ARTICLE INFO & ABSTRACT & & \\
\hline Article history: & В стать рассматривается & возможность & развития \\
Received & коммуникативных умений учащихся посредством & проектнй \\
Accepted & деятельности. Дается возможный список тем проектов для \\
Available online & восьмиклассников. & &
\end{tabular}

\section{Keywords:}

проектная деятельность;

учебные проекты;

The article reviews the possibility of developing the communicative универсальные учебные

действия;

УУД; skills of students through project activities. A possible list of project topics for eighth graders is given.

коммуникативные умения;

project-based learning;

communicative skills 
Важной задачей современной российской системы образования является формирование у школьников набора «универсальных учебных действий» (далее УУД), которые предоставляют каждому учащемуся возможность самостоятельно ставить цели обучения, находить и использовать необходимые средства и способы их достижения, уметь контролировать, оценивать учебную деятельность и ее результаты. Они создают условия для личностного развития и самореализации. УУД условно можно разложить на четыре блока: личностные, регулятивные, познавательные и коммуникативные.

Коммуникативные умения занимают особое место в наборе всех УУД. Так как, уровень сформированности коммуникативных качеств подростка влияет на его социальные навыки: умение вести продуктивный диалог со сверстниками и учителями, проявлять активность в образовательном процессе. Также высокий уровень развития коммуникативных умений необходим подросткам для успешной профессиональной ориентации. Умение работать в группе понадобится им в будущем для обучения в высшем учебном заведении и в реальной рабочей обстановке.

На сегодняшний день в педагогической науке существуют различные определения понятия «коммуникативные умения». К традиционному определению относится концепция Таисии Алексеевны Ладыженской - доктора педагогических наук, автора УМК по русскому языку издательства «Просвещения». К коммуникативным умениям она отнесла те, которые необходимы учащемуся для адекватного выражения собственной или понимания чужой мысли. Это умение определять тему, раскрыть основную мысль, собирать материал, систематизировать материал, правильно выражать свои мысли.

Анатолий Николаевич Щукин - педагог, доктор педагогических наук, лингвист, под речевым коммуникативным умением понимает «способность человека осуществлять то или иное речевое действие в условиях решения коммуникативных задач и на основе выработанных навыков и приобретенных знаний».

Кандидат педагогических наук Ольга Валентиновна Запятая причисляет к коммуникативным умения:

- точно, компактно, без искажения выражать свои мысли устно;

- оформлять высказывание письменно;

- слушать, вникать в суть и ставить вопросы к прослушанному тексту;

- самостоятельно изучать литературу по той или иной теме.

Таким образом, коммуникативные умения - возможность сотрудничества: мастерство слышать, слушать и понимать собеседника, планировать и согласованно выполнять совместную деятельность, распределять роли, взаимно контролировать действия друг друга, уметь договариваться, вести дискуссию, грамотно выражать свои мысли, оказывать поддержку друг другу и эффективно сотрудничать со всеми участниками образовательного процесса.

Коммуникативные умения на уроках развиваются во время чтения и написания текста и во время групповой работы, когда у учащихся есть возможность взаимодействовать друг с другом. Для нас наибольший интерес представляют групповая проектная деятельность. Проект представляет собой 
временную целенаправленную деятельность для получения уникального результата. Проектная деятельность - это стратегия обучения и преподавания, которая подразумевает работу над задачей или проблемой, которая воспринимается учащимися как актуальная для них. Конечный продукт - это нематериальный (интеллектуальный) или материальный продукт, который может быть представлен или продемонстрирован.

В идеале метод проектов позволяет учащимся глубже изучить тему со всех сторон. Проектная деятельность направлена на обучение навыкам общения, работе в группе, презентационным умениям, организации и управлению временем, умению оценивать свою работу и заниматься саморефлексией.

Проектная деятельность состоит из следующих этапов:

- выбор темы;

- планирование (постановка целей и задач);

- организация работы;

- сбор информации;

- разработка темы;

- создание продукта в форме;

- оценка проекта, корректировка;

- публичная презентация результатов проекта и конечных продуктов;

С учетом психологических особенной восьмиклассников оптимальным количеством проектов на одну четверть являются 1-2 проекта. Больше всего для них подходят проекты по направлениям: исследовательские, развивающие, воспитательные, социальные, экономические, экологические и технические. По временным рамкам - краткосрочные и среднесрочные. По масштабам - школьные и групповые (в классе). В первой четверти учебного года учащиеся 8- х классов изучают личность и общество, во второй сферу духовной культуры, в третей социальную сферу и в четвертой экономику. Создание уникальных проектов по таким темам дело крайне сложное (больше походят универсальные проекты). 
Табл. 1 Возможная формулировка тем проектов для восьмиклассников.

\begin{tabular}{|c|c|c|}
\hline Учебный год & $\begin{array}{l}\text { Содержание } \\
\text { занятий }\end{array}$ & Тематика проектов \\
\hline 1 четверть & $\begin{array}{l}\text { Личность и } \\
\text { обшество }\end{array}$ & $\begin{array}{l}\text { - Что делает человека человеком? } \\
\text { - } \text { Я как часть общества } \\
\text { - } \text { Защита природы } \\
\end{array}$ \\
\hline 2 четверть & $\begin{array}{l}\text { Сфера духовной } \\
\text { культуры }\end{array}$ & $\begin{array}{l}\text { - Почему мы не всегда поступаем } \\
\text { морально? } \\
\text { - } \text { «Совести у нігх нет!» } \\
\text { - } \text { Роль образования в моей жизни } \\
\text { - } \text { Самнгстр образования } \\
\text { - Свобода вероисповедания }\end{array}$ \\
\hline 3 четверть & Социальная сфера & $\begin{array}{l}\text { - Россія - многонациональная страна } \\
\text { - «Любая известная личность» - пример } \\
\text { девпантного поведения }\end{array}$ \\
\hline 4 четверть & Экономика & 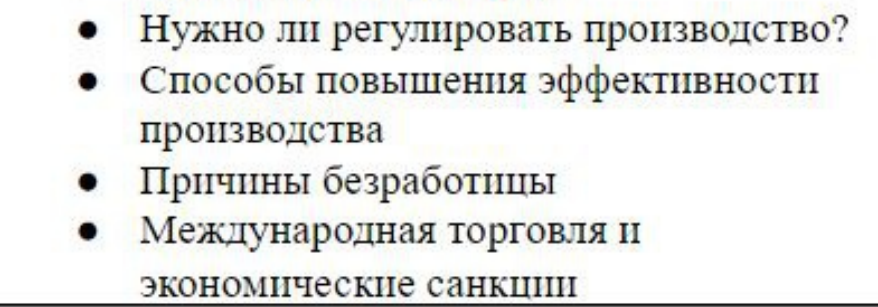 \\
\hline
\end{tabular}

Благодаря проектно-исследовательской деятельности у подростков формируются следующие умения и навыки.

1. Рефлексивные навыки. Умение осмыслить задачу, для решения которой недостаточно знаний; умение ответить на вопрос: чему нужно научиться, чтобы решить проблему?

2. Поисковые (исследовательские) навыки. Способность самостоятельно генерировать идеи, то есть изобретать способ действия, привлекая знания из разных областей; возможность самостоятельно искать недостающую информацию в информационном поле; возможность запрашивать недостающую информацию у эксперта (преподавателя, консультанта, специалиста); умение находить несколько решений проблемы; умение выдвигать гипотезы; способность устанавливать причинно-следственные связи.

3.Навыки оценочной самостоятельности. Оценивания своей работы и работы других. Формирование адекватной самооценки.

4.Коммуникативные умения. Умения и навыки работы в сотрудничестве. Навыки коллективного планирования; умение взаимодействовать с любым партнером; навыки взаимопомощи в группе в решении общих задач; навыки делового партнерства; умение находить и исправлять ошибки в работе других участников группы. 
Навыки общения. Умение инициировать учебное взаимодействие со взрослыми - вступать в диалог, задавать вопросы и т. д.; умение вести дискуссию; умение отстаивать свою точку зрения; умение находить компромисс; навыки интервьюирования, устный опрос и т. д.

На разных этапах проектной деятельности развиваются различные коммуникативные умения. На первом организационно-подготовительном этапе учащиеся обмениваются мнением, развивают умение ставить цель, распределять функции между участниками группы. На поисково-исследовательском этапе формируется умение поиска и обработки информации, а также умение вести дискуссию в группе, предупреждать и решать конфликтные ситуации. Во время третьего отчетно-оформительского этапа развивается умение грамотно выражать свои идеи на бумаге, сотрудничать с другими. Умение презентовать проект, объективно оценивать работу других и свою - развиваются на последнем информационно-презентативном этапе.

Презентационные навыки. Умение вести монологическую речь; умение уверенно держать себя во время выступления; умение использовать различные средства наглядности в презентации; умение отвечать на незапланированные вопросы.

В конце следует отметить, что групповая проектная деятельность оказывает положительное и существенное влияние на развитие коммуникативных умений школьников.

\section{Список литературы}

Запятая О. В. Общие умения коммуникации как компонент содержания образования. Красноярск, 2005. $-6 \mathrm{c}$.

Коджаспирова Г. М., Коджаспиров А. Ю. Педагогический словарь: для студ. высш. и сред. пед. учеб. заведений. - М.: Издательский центр «Академия», 2003. -176 с.

Ладыженская Т. А. Система обучения сочинениям в V-VIII классах. М., 1967. - 17 с.

Селевко Г. К. Современные образовательные технологии: учебное пособие. - М: Народное образование, 1998. - 256 с.

Щукин А. Н. Лингводидактический энциклопедический словарь. М., 2008. - 278 с. 


\section{Article text in English}

An important task of the modern Russian education system is the formation of a set of "universal learning activities" (hereinafter UED) for schoolchildren, which provide each student with the opportunity to independently set learning goals, find and use the necessary means and means of achieving them, be able to control, evaluate learning activities and its results . They create conditions for personal development and selfrealization. A UCD can conditionally be decomposed into four blocks: personal, regulatory, cognitive, and communicative.

Communication skills occupy a special place in the recruitment of all UCD. Since, the level of formation of the communicative qualities of a teenager affects his social skills: the ability to conduct a productive dialogue with peers and teachers, to be active in the educational process. Also, a high level of development of communication skills is necessary for adolescents for successful vocational guidance. They will need the ability to work in a group in the future to study in a higher educational institution and in a real working environment.

Today in pedagogical science there are various definitions of the concept of "communicative skills." The concept of Taisiya Alekseevna Ladyzhenskaya, the doctor of pedagogical sciences, the author of the Russian language teaching of the publishing house Prosveshcheniya, is a traditional definition. To the communicative skills she attributed those that are necessary for the student to adequately express their own or understand someone else's thoughts. This is the ability to determine the topic, to reveal the main idea, to collect material, to systematize the material, to properly express their thoughts.

Anatoly Nikolaevich Schukin is a pedagogue, doctor of pedagogical sciences, a linguist, by speech communicative ability means "the ability of a person to perform a particular verbal action in the context of solving communicative tasks and on the basis of the developed skills and acquired knowledge".

Candidate of Pedagogical Sciences Olga Valentinovna. The comma ranks communication skills as:

- accurately, compactly, without distortion, express your thoughts orally;

- make a statement in writing;

- listen, delve into the essence and put questions to the heard text;

- independently study the literature on a particular topic.

Thus, communication skills are the possibility of cooperation: mastery of hearing, listening and understanding the interlocutor, planning and coordinatingly carrying out joint activities, assigning roles, mutually controlling each other's actions, being able to negotiate, leading a discussion, competently expressing their thoughts, supporting each other and effectively cooperate with all participants of the educational process.

Communication skills in the classroom are developed during the reading and writing of the text and during group work, when students have the opportunity to interact with each other. For us, the greatest interest are group project activities. The project is a temporary purposeful activity to obtain a unique result. Project activity is a learning and teaching strategy that involves working on a task or problem that is perceived by 
students as relevant to them. The end product is an intangible (intellectual) or tangible product that can be presented or demonstrated.

Ideally, the project method allows students to further explore the topic from all angles. Project activities are aimed at teaching communication skills, group work, presentation skills, organization and time management, the ability to evaluate their work and engage in self-reflection.

The project activity consists of the following stages:

- selection of a topic;

- planning (setting goals and objectives);

- work organization;

- collection of information;

- development of the topic;

- creation of a product in the form;

- project evaluation, adjustment;

- public presentation of the project results and final products;

Taking into account the psychological peculiarities of eighth-graders, the optimal number of projects per one quarter is 1-2 projects. The most suitable projects for them are in the following areas: research, development, educational, social, economic, environmental and technical. In the time frame - short and medium. In scale school and group (in class). In the first quarter of the school year, pupils of the 8th grade study personality and society, in the second sphere of spiritual culture, in the third social sphere and in the fourth economy. Creating unique projects on such topics is extremely difficult (universal projects are more like). 
Tab. 1 Possible wording of project themes for eighth-graders.

\begin{tabular}{|c|c|c|}
\hline Academic year & Activity content & Projects \\
\hline 1 quarter & Person and society & $\begin{array}{l}\text { - What makes a person a person? } \\
\text { - I, as a part of society } \\
\text { - Protection of nature }\end{array}$ \\
\hline 2 quarter & $\begin{array}{l}\text { Sphere of spiritual } \\
\text { culture }\end{array}$ & $\begin{array}{l}\text { - Why do we not always act morally? } \\
\text { - "They have no!" } \\
\text { - The role of education in my life } \\
\text { - I am the minister of education } \\
\text { - The most relevant professions of the future } \\
\text { - conscienceReligious freedom }\end{array}$ \\
\hline 3 quarter & Social sphere & $\begin{array}{l}\text { - Russia is a multinational country } \\
\text { - "Any known person" is an example of } \\
\text { deviant behavior }\end{array}$ \\
\hline 4 quarter & Economy & $\begin{array}{l}\text { - Need to regulate production? } \\
\text { - Ways to improve production efficiency } \\
\text { - The causes of unemployment } \\
\text { - International trade and economic sanctions }\end{array}$ \\
\hline
\end{tabular}

Thanks to the design and research activities in adolescents, the following skills are formed.

1. Reflexive skills. The ability to comprehend a task for the solution of which is not enough knowledge; ability to answer the question: what do you need to learn to solve a problem?

2. Search (research) skills. The ability to independently generate ideas, that is, to invent a way of action, attracting knowledge from different areas; the ability to independently search for missing information in the information field; the ability to request the missing information from an expert (teacher, consultant, specialist); the ability to find several solutions to the problem; the ability to put forward hypotheses; ability to establish causal relationships.

3. Skills estimated independence. Evaluating your work and the work of others. Formation of adequate selfesteem.

4. Communicative skills. Skills and abilities to work in cooperation. Collective planning skills; ability to interact with any partner; skills of mutual assistance in the group in solving common problems; business partnership skills; the ability to find and correct errors in the work of other group members.

Communication skills. The ability to initiate learning interaction with adults - to engage in dialogue, ask questions, etc .; the ability to lead a discussion; the ability to defend their point of view; the ability to find a compromise; interviewing skills, oral questioning, etc.

At different stages of project activities, various communication skills develop. At the first organizational and preparatory stage, students exchange views, develop the ability to set a goal, to distribute functions between the group members. At the search and research stage, the ability to search and process information is formed, as well as the ability to lead a group discussion, to prevent and solve conflict situations. During the third reporting and design stage, the ability to competently express their ideas on paper and to cooperate with others develops. The ability to present a project, objectively evaluate the work of others and one's own is developed at the last informational and presentational stage. 
Presentation skills. The ability to conduct a monologue speech; the ability to confidently keep yourself during a performance; ability to use various means of visualization in the presentation; ability to answer unplanned questions.

In the end, it should be noted that group project activities have a positive and significant impact on the development of communicative skills of schoolchildren.

\section{References}

Comma OV. General communication skills as a component of educational content. Krasnoyarsk, 2005. - 6 p. G. Kodjaspirova, A. Yu. Kodjaspirov. Pedagogical Dictionary: for students. higher and $\mathrm{n}$ ped. studies. institutions. - M .: Publishing Center "Academy", 2003. -176 p.

Ladyzhenskaya T. A. The system of teaching essays in grades V - VIII. M., 1967. - 17 p.

Selevko GK Modern educational technologies: a tutorial. - M: National Education ,1998. - 256 p.

Schukin A. N. Lingvodidactic Encyclopedic Dictionary. M., 2008. - 278 p. 


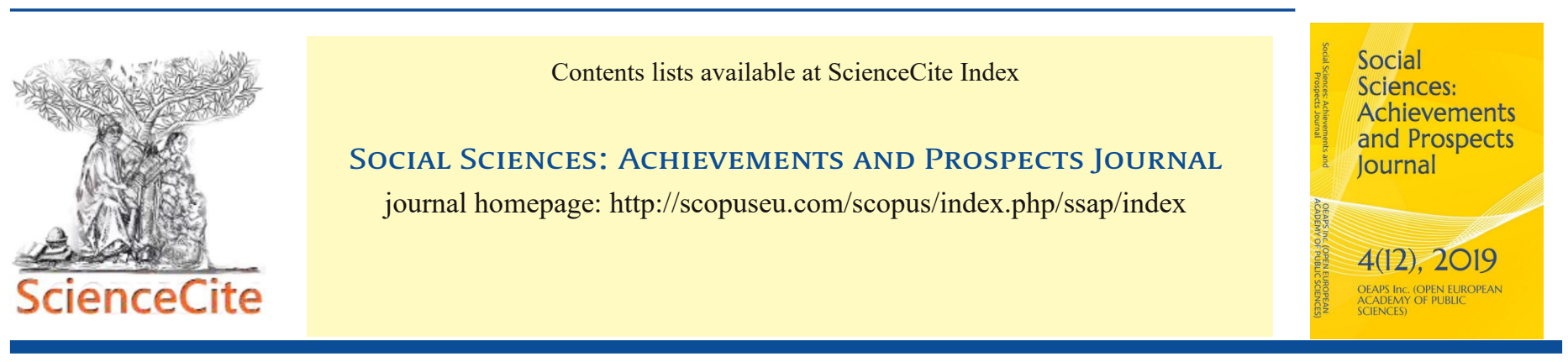

КАЗАХОЯЗЫЧНЫЕ ВКРАПЛЕНИЯ В ПУБЛИЦИСТИКЕ: КОММУНИКАТИВНО-ПРАГМАТИЧЕСКИЙ АСПЕКТ

\section{Балмагамбетова Жанна Толеуовна}

Карагандинский государственный университет имени академика Е.А. Букетова, доктор филологических наук, профессор кафедры русского языка и литературы имени Г.А. Мейрамова, Казахстан, Караганда janna1965@rambler.ru

\section{Стеничкина Татьяна Викторовна}

Карагандинский государственный университет имени академика Е.А. Букетова, магистрант, Казахстан, Караганда

\section{KAZAKH-SPEAKING INCLUSIONS IN PUBLICISM: COMMUNICATIVE AND PRAGMATIC ASPECT}

\section{Balmagambetova Zhanna Toleuovna}

Karaganda State University named after Academician Ye.A. Buketov, Doctor of Philology, Professor, Department of Russian Language and Literature named after G.A. Meyramova, Kazakhstan, Karaganda

\section{Stenichkina Tatyana Viktorovna}

Karaganda State University named after Academician Ye.A. Buketov, master student, Kazakhstan, Karaganda

\section{ARTICLE INFO ABSTRACT}

\section{Article history:}

Received

Accepted

Available online

\section{Keywords:}

иноязычные вкрапления;

казахоязычное вкрапление;

прагматический; интенция; СМИ;

языковые контакты;

коммуникачия; речевое

воздействие; foreign language

inclusions; kazakh-speaking

inclusions; pragmatic; intention;

media; language contacts;

communication; speech impact
Анализу подвергаются прагматическая актуальность казахоязычных вкраплений, исследуются коммуникативные причины ввода вкраплений, определяются условия их интенционального использования. Ряд иноязычных единиц изучен на материале СМИ Казахстана за 2017-2019 гг. Вкрапления рассматриваются как носители прагматической информации, выдвигая на первый план понятие речевого воздействия. Исследование казахоязычных вкраплений в современной публицистике Казахстана способствует уяснению закономерностей межъязыковых и культурных контактов, постижению взаимодействия концептуальных категорий.

The pragmatic relevance of kazakh-speaking inclusions is analyzed, the communicative reasons for introducing inclusions are examined, the conditions for their intentional use are determined. A number of foreign-language units studied on the material of the media of Kazakhstan for 2017-2019. The inclusions are considered as carriers of pragmatic information, highlighting the concept of speech impact. The study of inclusions in publicism in Kazakhstan contributes to the understanding of the patterns of interlingual contacts, and the comprehension of the interaction of conceptual categories.

(c) 2019 The Author. Published by OEAPS Inc. This is an open access article under the CC BY-NC-ND license (http://creativecommons.org/licenses/by-nc-nd/4.0/). 
Значительные изменения в лексическом составе русского языка, самом подвижном и активно реагирующем уровне, вызванные трансформациями в политическом, идеологическом, государственном устройстве, привлекают внимание современных исследователей. Иноязычные слова являются неотъемлемой характеристикой языка современных средств массовой информации.

Так, одной из особенностей текстов современной русскоязычной публицистики Казахстана является довольно активное использование казахоязычных вкраплений, причем можно отметить тенденцию к росту употребления таких элементов.

Таким образом, важно уточнить коммуникативно-прагматические характеристики вкраплений, что позволит точнее определить их статус в системе иноязычных элементов. Рассмотрим указанные языковые единицы на материале статей и информационных материалов средств массовой информации Казахстана, так как жанровые особенности и тематика газетно-публицистического стиля предполагают наличие в тексте вкраплений из казахского языка, что позволит выявить их прагматическую функцию.

Опираясь на существующие точки зрения, отметим неоднозначность отношения лингвистической науки к иноязычным вкраплениям. Термин иноязычные вкрапления в научный дискурс ввел А.А. Леонтьев. Понимая это языковое явление в широком смысле, как «"сосуществование" двух текстов», А. А. Леонтьев считает вкраплениями «вставленные иноязычные "сегменты", слова, выступающие в иноязычном звуковом и Или графическом, грамматическом оформлении» [1, с.61]. Рассматривая вкрапления как «внесистемные иноязычные элементы», предлагает разноуровневую классификацию (лексемный, морфемный, фонемный и уровень звукотипов) по 16 типам. Это исследование подтолкнуло к последующему разностороннему изучению вкраплений.

В дальнейшем Л.П. Крысин определяет иноязычные вкрапления как «незамкнутые группы слов». Употребление их обусловлено либо тематикой, «либо степенью знакомства говорящего с иностранным языком, некоторыми стилистическими или жанровыми особенностями речи» [2, с.60]. Рассматривая иноязычные вкрапления, экзотизмы и заимствованные слова, Крысин Л.П. выделяет две большие группы:

1) слова и словосочетания, которые имеют интернациональный характер и могут быть употреблены в текстах любого культурного языка. Кроме общеизвестных латинских выражений (alter ego, postfactum, terra incognita и др.), относит к этой группе выражения из живых европейских языков (мерси, napдон, гуд бай и пр.);

2) иноязычные элементы, не принадлежащие к кругу устойчивых и интернациональных. «Их использование в тексте часто связано с художественно-стилистическими задачами, а иногда отражает индивидуальное словоупотребление». В этом случае показателен пример - признание Г.Г.Нейгауза, автора книги по игре на фортепьяно, который признался: «Так как я смолоду знаю несколько языков и привык к известным выражениям на данном именно языке, то я не постеснялся записать эти выражения, как они мне приходили в голову» [2, с.60-61].

Этот пример подводит нас к мысли об использовании в речи иноязычных вкраплений билингвами, что отражает современную языковую ситуацию в Казахстане. Так, Ю.Т. Листрова-Правда предлагает рассматривать вкрапления в качестве разновидности билингвизма, учитывая их межкультурную специфику. Несомненно, отмечается и стилистическая особенность иноязычных вкраплений, которая напрямую зависит от содержания сообщения. По мнению Ю.Т. Листровой-Правды, важнейшие факторы, влияющие на принципы отбора и использования иноязычных вкраплений, это: 1) внутренние закономерности данного языка, 2) характер его контактов с другими языками, 3) общественно-политическая и языковая ситуация в стране [3, с.119-120]. 
Разрабатывая тему прагматики вкрапления в структурно-семиотическом плане,

С.Г. Николаев полагает, что графическое оформление иноязычного элемента указывает на его инаковость и способно привлекать внимание читателя. Иноязычная графика вкраплений создает двуязычный и двуграфический текст. Такое сближение двух коммуникативных систем вызывает дополнительные ассоциации у читателя и создает соответствующий образ языка элемента, а также имеет экспрессивную функцию и повышает эстетический вес текста. Причем знак графической презентации не выступает для вкрапления как дифференциальный, вкрапление может быть и транслитерировано, т.е. передано алфавитными средствами окружения [4, с.9-10].

К прагматическим факторам относят самую разнообразную информацию и условия коммуникации, а также фоновые знания, которые позволяют установить смысл языковых выражений и высказываний в ситуативном контексте. Говорящий может использовать вкрапления таким образом, чтобы оказывать наибольшее воздействие на адресата, что будет способствовать эффективному достижению коммуникативной цели.

Современные СМИ имеют двустороннюю природу: не только сами отражают речевую практику общества, но и формируют ее, попадая в топ просмотров, получая максимально широкое распространение, можно сказать, участвуют в формировании современной картины мира.

Коммуникативное намерение автора-публициста - убедить читателя не просто в правомерности, но именно в правильности авторского видения, авторской трактовки действительности. По мнению Клушиной Н.И., «весь публицистический текст организуется под контролем этой глобальной авторской интенции» [5, с.61].

Таким образом, именно интенциональные категории текста (как коммуникативные намерения) становятся текстообразующими категориями, которые структурируют текст и подчиняют себе все остальные лексико-семантические и стилистические ресурсы выразительности.

Публицистический, шире - авторский текст, в интернет-изданиях пишется с учетом важной особенности - мгновенной реакции читателя, возможной полемике в комментариях. Прямое воздействие на адресата, возможность «сотворчества» читателя не просто создают иллюзию диалога, а делают его вполне реальным. Поэтому можно говорить об особой текстообразующей функции вкраплений: если для русскоязычного монолингва-читателя казахские слова будут восприниматься как иноязычные, чужеродные, то для билингва - родные и понятные. Конкретная графическая оболочка слова всегда связана с конкретным языком, культурой.

Показательно использование вкраплений в публицистических текстах в качестве вторичных (эмотивных, коннотативных) номинаций, вносящих элемент оценочности, выражающих аксиологические установки говорящего. Рассмотрим на примерах:

Даже учитывая уверенности «Nur-Otan» в победе и определенности с победителем, нужно учитьвать, что эта избирательная байга и сами выборы станут некими лекалами, по которым в следующеем году пройдут парламентские выборы [Nur.kz, 09.04.2019].

Так, политическая байга - это не просто «избирательная гонка» (привычное для нас выражение из российских изданий). Словом байга автор дает нам понять, что это трудновыполнимое, тяжелое соревнование, когда к финишу приходят не все. При этом понятен тот накал страстей, нервное ожидание для всех зрителей, а не только участников. Кульминацией выступает вручение очень дорогого приза победителю, ради которого стоит побороться, сражаться за победу. Еще пример: 
В стране продолжается байга по комплексному решению проблемы переработок среди государственных служащих [Казахстанская правда, 06.04.2018].

По мнению Кожевниковой М.А., использование вкраплений в переносном значении актуализирует эмоционально-оценочный компонент для выражения субъективной точки зрения автора на рассматриваемое явление или предмет [6, с.195]. То же слово байга в материале ироничного характера передает и более сложные отношения: досаду, ощутимо критическую позицию автора произведения к предмету речи. Такие исследователи, как Манина С.И., Норлусенян В.С. считают, что иноязычие часто сопряжено с комизмом конкретной ситуации, иронией автора $[7 ; 8]$.

Можно отметить еще одну особенность: постоянное внедрение и обновление лексических средств, называющих новые, актуальные явления, связанные с культурной, политической жизнью государства. Так, только на начальном этапе употребления таких понятий, как Eлбасы, Pухани жанzыру и других требуется перевод или комментарий, со временем, став частотными в употреблении, пояснения воспринимаются уже излишними.

Как видим, успешность понимания слов-вкраплений из казахского языка связана с ориентацией на потенциального реципиента и зависит от связи выражения с ситуативно-реальными обстоятельствами текстопорождения, которые и выступают основой для его усвоения. Помогает в этом насыщенность контекста семантической, возможно, аллюзивной информацией общеизвестного характера.

В результате анализа текстов СМИ, можно выделить определенные функции вкраплений с различной долей участия в структурной и смысловой организации текста. Прежде всего, они функционируют как номинации в событийной информации, обозначая казахстанские реалии:

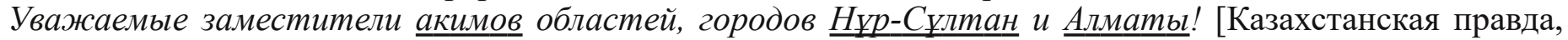
08.04. 2019].

Встретился с жителями, пообщался с аксакалами аула [Nur.kz, 04.04.2019].

Гостей встречали баурсаками, шашу и кумыссом [Казахстанская правда, 07.11. 2018]

В материалах аналитического характера или в авторских репортажах использование казахоязычных вкраплений обусловлено уже их прагматическим свойством: на первый план выходит возможность не только выражать коммуникативные интенции говорящего, но и воздействовать на адресата, придавая тексту экспрессивность и эмоциональность.

Вот что такое қазақ күресі! А тут такой демари ...[Казахстанская правда, 04.12. 2018].

"Елбасы, рахмет сізге (спасибо вам) за то, что принимаете указы и законы по сочиильной защите ветеранов войны в Афганистане, но на местах местные власти и чиновники игнорируют ваши законодательные акты", - отметил Мамраев [Nur.kz, 17.02.2019].

Не подлежит сомнению, что автор использовал лексику казахского языка не потому, что он не в достаточной степени владеет русским языком, а потому, что речь его направлена читателям, которые в состоянии его понять, более того, оценить меткое слово. Исследователи отмечают особую экспрессивность современного публицистического текста, усиление личностного авторского начала, которое проистекает из коммуникативного права говорящего на открытое самовыражение, на «возможность подвергать индивидуально-субъективным оценкам любой предмет речи и компонент коммуникативного акта» [9, c. 50]. Открытая позиция автора, его субъективная оценка происходящего выражается, конечно, и в наборе используемых лексических средств. 
Предваряющий комментарий к онлайн-трансляции заседания Правительства РК состоит из двух предложений, при этом в каждом из них мы наблюдаем вкрапления:

«В Yкімет уйі проходит заседание Правительства Республики Казахстан, передает Каzрravda.kz. Ha повестке заседания: ход реализачии Государственной программы поддержки и развития бизнеса "Дорожная карта бизнеса-2020", сочиальные проекты в рамках реализации инициативы Елбасы "Әлеуметтік камкорльк"»» [Kazpravda.kz. 02.04.2019].

Обратим внимание, что использование в текстах номинаций административно-политического устройства, политических терминов на казахском языке в СМИ является логичным. Названия большинства общественных, политических и культурных государственных программ вводится на государственном языке, следовательно, происходит автоматизация речевого навыка, связанная с частотой употребления данных единиц, как у авторов, так и читателей. Употребление казахоязычных вкраплений позволяет читателю актуализировать различные не только смысловые, но и лингвокультурные компоненты.

Обратим внимание, что даже в одном источнике может не быть единого варианта написания. Взаимовлияние двух языков выражается в вариантах написания и произношения, которое мы наблюдаем при попытке письменно передать имена собственные (например, географические названия, имена людей):

Проект строительства ГЛК Кок-Жайляу могут изменить.

Разработчик проекта "Кок Жайлау" ответил противникам стройки.

Я уже говорил в одном из интервью о том, что многие, так называемые, зашитники Кокжайлау на самом деле, в первую очередь, защчищают свою привилегию в использовании природы плато узким кругом [Nur.kz, 15.05.2018].

Та же новость в Казправде: Токаев поддержал решение отложить строительство "Көк Жайлау"

Еще пример передачи имени собственного в одном и том же материале: «Bbl знаете Ләззәт Myратовну как известного журналиста, квалифицированного специалиста телевидения и хоромего топ-менеджера», - написал министр.

Танысбай Ляззат Муратовна родилась 11 октября 1973 года в Восточно-Казахстанской области, в селе Урджар [Казправда, 08.04.2019].

Как видим, происходит смешение графического облика слова. В одном и том же тексте может быть несколько вариантов написания: с дефисом и без, на русском и казахском языках, а также на казахском с ошибками как отражение явления интерференции. Показателен последний пример в выражении авторской интенции: графически выделенное сочетание имени и отчества на двух языках.

Прослеживается связь со способом получения информации автором: письменный (пресс-релиз) или устный (прямая речь, интервью). При письменном варианте официального сообщения придерживаются варианта казахской графики, допускают меньше ошибок.

В отборе слов-вкраплений, их характере и способе презентации в казахстанском медиа-дискурсе прослеживаются особенности межкультурной коммуникации Казахстана: как показывает собранный и представленный материал, авторы в большинстве случаев стараются внести в текст пояснение, комментарий, от которого зависит успешность коммуникации, стараются явно не обнаруживать и не противопоставлять свое языковое и культурное отличие, не дистанцируются от читателя.

Можно выделить следующие закономерные условия употребления казахоязычных вкраплений: во-первых, необходимость номинации государственных реалий, во-вторых, возможность придания особой выразительности и экспрессивности тексту, используя весь коммуникативно-прагматический потенциал иноязычного слова. Конечно, не все публицистические и информационные материалы насыщены казахскими вкраплениями, но все же они встречаются довольно часто и довольно узнаваемы в таких масс- 
медиа ресурсах, как «», «Sputnik», «Караван», «Казправда», «Экспресс-К» и других.

Интересно замечание Новоженовой 3.Л. о том, что важную роль в использовании иноязычных вкраплений играет и такой фактор, как языковая мода, представляющий собой сложное социально-речевое явление $[10$, с.39]. Так, изменение статуса казахоязычных вкраплений в современных текстах публицистики обусловлено процессами внутри государства: сменой статуса контактируемых языков, усилением межкультурных связей, расширением влияния казахской культуры, интенсификацией обмена информацией.

Между тем, сложно проследить какую-либо строгую закономерность в их употреблении. Вероятно, при выборе указанных слов решающим фактором стала их коммуникативная актуальность. Своеобразие текстов СМИ формируется сочетанием научного знания, официальной государственной номенклатуры, терминологии и обыденной речи, что создаёт неповторимую систему образного мироощущения. Такое сочетание вызвано направленностью на максимально широкий охват читательской аудитории.

Следует сделать вывод, что появление в текстах СМИ казахоязычных вкраплений обусловлено следующими причинами, во-первых, от знания говорящим или пишущим субъектом другого языка, в данном случае казахского; во-вторых, от прагматического намерения, интенций автора, тех коммуникативных целей, которые он ставит перед собой. Также на активное использование вкраплений влияет комплекс внешних причин языкового и культурного плана: тип текста, его жанрово-стилистические характеристики; характер контактов между языками; интенсивность культурных контактов между носителями языков.

\section{Список литературы}

Леонтьев А.А. Иноязычные вкрапления в русскую речь //Вопросы культуры речи. - 1966. - №7. - С. 60-68.

Крысин Л.П. Русское слово, свое и чужое: Исследование по современному русскому языку и социолингвистике. - М.: Языки славянской культуры, 2004. - С.59-64.

Листрова-Правда Ю.Т. Иноязычные вкрапления-библеизмы в русской литературной речи XIX-XX вв. // Вестник Воронежского государственного университета. Сер. 1. - 2001. - № 1. - С. 119-139.

Николаев С.Г. Феноменология билингвизма в творчестве русских поэтов: автореферат диссер. ... д-ра филол. наук. - Ростов н/Д, 2006. - 46с.

Клушина Н. И. Коммуникативная стилистика публицистического текста // Мир русского слова. - №4. 2008. - С. 67-70.

Кожевникова М. А. Художественный мультилингвизм в языке писателя эмигранта Б. Хазанова: диссертация на соискание ученой степени кандидата филологических наук. - Красноярск, 2016. - 201с.

Манина С.И. Иноязычные вкрапления в аспекте прагматики // Культурная жизнь Юга России. - 2008. №2. - С.141-143.

Норлусенян В.С., Григорьева Н.О. Иноязычные вкрапления в современном художественном тексте: коммуникативно-прагматический потенциал. - Филологические вопросы, 2014. - С. 75-82.

Матвеева Т.В. Нормы речевого общения как личностные права и обязанности //Юрислингвистика - 2: Русский язык в его естественном и юридическом бытии. - Барнаул, 2000. - С.46-55.

Новоженова 3. Л. Иноязычные вкрапления как дискурсивное явление: русское слово в чужом тексте // Вестник Балтийского федерального университета им. И. Канта. - Серия: Филология, педагогика, психология, 2012. - №8 - С. 37-42. 


\section{Article text in English}

Significant changes in the lexical composition of the Russian language, the most mobile and actively responding level, caused by transformations in the political, ideological, state structure, attract the attention of modern researchers. Foreign words are an integral characteristic of the language of modern media.

Thus, one of the peculiarities of the texts of modern Russian-speaking journalism in Kazakhstan is the rather active use of Kazakh-speaking inclusions, and we can note a tendency to increase the use of such elements.

Thus, it is important to clarify the communicative and pragmatic characteristics of the inclusions, which will make it possible to more accurately determine their status in the system of foreign language elements. Consider the indicated language units on the material of articles and information materials of the mass media of Kazakhstan, since the genre features and themes of the newspaper-publicistic style suggest the presence of blotches from the Kazakh language in the text, which will allow to reveal their pragmatic function.

Based on the existing points of view, we note the ambiguity of the attitude of linguistic science to foreign impregnations. The term " foreign language blotches" was introduced into the scientific discourse by A.A. Leontyev. Understanding this linguistic phenomenon in a broad sense, as " " the coexistence "of two texts," A. A. Leontiev considers interspersed "inserted foreign-language" segments, "words appearing in a foreign sound and / or graphic, grammatical design" [1, p. 61]. Considering blotches as "non-systemic foreignlanguage elements", it offers a multi-level classification (lexeme, morpheme, phoneme, and level of sound types) according to 16 types. This study prompted the subsequent comprehensive study of inclusions.

In the future, L.P. Krysin defines foreign words as "unclosed groups of words". Their use is due to either the theme, "or the degree of acquaintance of the speaker with a foreign language, some stylistic or genre features of speech" [2, p.60]. Considering foreign impregnations, exoticism and borrowed words, L. Krysin. identifies two large groups:

1) words and phrases that are international in nature and can be used in the texts of any cultural language. In addition to well-known Latin expressions (alter ego, postfactum, terra incognita, etc.), this group includes expressions from living European languages (Merci, sorry, good bye, etc.);

2) foreign-language elements that do not belong to the circle of sustainable and international. "Their use in the text is often associated with artistic and stylistic tasks, and sometimes reflects individual usage." In this case, an example is the recognition of G.G. Neuhaus, the author of a book on playing the piano, who admitted: "Since I know several languages from my youth and have become accustomed to known expressions in this particular language, I did not hesitate to write these expressions as they came to my mind "[2, p.60-61].

This example brings us to the idea of the use of foreign language injections in bilingual speech, which reflects the current linguistic situation in Kazakhstan. So, Yu.T. Listrova-Pravda proposes to consider blotches as a type of bilingualism, given their intercultural specificity. Undoubtedly, there is also a stylistic peculiarity of foreign language patches, which directly depends on the content of the message. According to Yu.T. Listrava Pravda, the most important factors influencing the principles of selection and use of foreign language interspersions are: 1) the internal laws of a given language, 2) the nature of his contacts with other languages, 3 ) the socio-political and language situation in the country [3, p.119 -120].

In developing the theme of pragmatics interspersed in structural and semiotic terms, S.G. Nikolaev believes that the graphic design of the element in foreign language indicates its otherness and is able to attract the attention of the reader. The foreign language blotches create bilingual and bicraphic text. Such a convergence of two communicative systems causes additional associations for the reader and creates the corresponding image of the element language, and also has an expressive function and increases the aesthetic weight of the text. Moreover, the sign of a graphical presentation does not act as a differential for blotches, the blotches can also be transliterated, i.e. transferred by the alphabetic environment [4, p.9-10]. 
Pragmatic factors include the most diverse information and conditions of communication, as well as background knowledge, which allow us to establish the meaning of language expressions and statements in a situational context. The speaker can use blotches in such a way as to have the greatest impact on the addressee, which will contribute to the effective achievement of the communicative goal.

Modern media have a two-way nature: not only they themselves reflect the speech practice of society, but also form it, getting into the top views, getting the widest possible distribution, one can say, participate in shaping the modern picture of the world.

The communicative intention of the author-publicist is to convince the reader not only of the legitimacy, but precisely of the correctness of the author's vision, the author's interpretation of reality. According to N.I. Klushina, "the entire publicistic text is organized under the control of this global authorial intention" [5, c.61].

Thus, it is the intentional categories of the text (as communicative intentions) that become text-forming categories that structure the text and subordinate all other lexical-semantic and stylistic resources of expressiveness to themselves.

The journalistic, more widely - the author's text, is written in Internet publications taking into account an important feature - an instant reader reaction, a possible controversy in the comments. The direct impact on the addressee, the possibility of "co-creation" of the reader does not just create the illusion of dialogue, but make it quite real. Therefore, we can speak of a special text-forming function of inclusions: if for the Russianspeaking monolingual reader Kazakh words will be perceived as foreign-language, alien, then for bilingual native and comprehensible. The specific graphical shell of the word is always associated with a specific language, culture.

It is indicative of the use of blotches in journalistic texts as secondary (emotive, connotative) nominations that introduce an element of evaluation, expressing the axiological attitudes of the speaker. Consider with examples:

Even taking into account the confidence of "Nur-Otan" in victory and certainty with the winner, it must be borne in mind that this electoral baiga and the elections themselves will become some kind of patterns for which parliamentary elections will be held next year [Nur.kz, 04/09/2019] .

So, political baiga is not just a "election race" (an expression from Russian publications that is familiar to us). In the word of baiga, the author gives us to understand that this is a difficult, difficult competition, when not all come to the finish line. At the same time, the tension of passions, nervous expectation for all viewers, not just the participants, is understandable. The culmination is the presentation of a very expensive prize to the winner, for whom it is worth fighting, to fight for the victory. Another example:

continues in the country Baiga on a comprehensive solution to the problem of processing among government officials [Kazakhstanskaya Pravda, 04.04.2018].

According to MA Kozhevnikova, the use of inclusions in a figurative sense actualizes the emotionalevaluative component for expressing the author's subjective point of view on the phenomenon or subject under consideration [6, p. 195]. The same word baiga in the material of an ironic nature conveys more complex relationships: annoyance, palpably critical position of the author of the work to the subject of speech. Such researchers as Manina S.I., Norlusenyan V.S. consider that foreign language is often fraught with the comic of a particular situation, the author's irony [7; eight]. 
One more feature can be noted: the constant introduction and updating of lexical means, which call new, relevant phenomena connected with the cultural and political life of the state. So, only at the initial stage of the use of such concepts as Elbasy, Ruhani Zhangyryu and others a translation or commentary is required, with time becoming frequency in use, explanations are perceived as superfluous.

As you can see, the success of understanding the words-intersperses from the Kazakh language is associated with a focus on the potential recipient and depends on the connection of the expression with the situationalreal circumstances of text-generation, which serve as the basis for its assimilation. The saturation of the context helps with this semantic, possibly allusional information of a well-known nature.

As a result of the analysis of media texts, it is possible to identify certain functions of blotches with varying degrees of participation in the structural and semantic organization of the text. First of all, they function as nominations in the event information, denoting Kazakhstani realities:

Dear deputy akims of the regions, cities of Nur-Sultan and Almaty! [Kazakhstanskaya Pravda, 08.04. 2019].

Met with residents, talked with aksakals aul [Nur.kz, 04/04/2019].

Guests were met with baursaks, shashu and koumiss [Kazakhstanskaya Pravda, 07.11. 2018]

In materials of an analytical nature or in author's reports, the use of Kazakh-speaking inclusions is due to their pragmatic property: the possibility of not only expressing the communicative intentions of the speaker, but also affecting the addressee, giving the text expressiveness and emotionality, comes to the fore.

That's what қаққ күреi! And then there is such a demarche ...[Kazakhstanskaya Pravda, 04.12. 2018].

"Elbasy, rakhmet sizge (thank you) for adopting decrees and laws on the social protection of veterans of the war in Afghanistan, but local authorities and local officials ignore your legislation," Mamrayev said [Nur.kz, 02.17.2019].

There is no doubt that the author used the vocabulary of the Kazakh language, not because he did not speak the Russian language sufficiently, but because his speech was directed to readers who are able to understand him, moreover, appreciate the apt word. The researchers note the special expressiveness of the modern journalistic text, the strengthening of the personal author's beginning, which stems from the communicative right of the speaker to open self-expression, to "the ability to subject individual subjective assessments to any speech object and component of the communicative act" [9, p. 50]. The open position of the author, his subjective assessment of what is happening is expressed, of course, in the set of lexical tools used.

Is preceded by a comment to the online broadcast of the Republic of Kazakhstan Government meeting consists of two sentences, while in each of them we observe blotches

"In Ukimet Uiy hosts meeting of the Government of Kazakhstan, reports Kazpravda.kz.On the agenda of the meeting: the implementation of the State program of support and development of business "Business Road Map 2020", social projects in the framework of the initiative of Elbasy "Yleumettik қаткоrlyк"»'Kazpravda.kz, 04/02/2019].

Let us pay attention that the use of administrative and political structure in political texts, political terms in the Kazakh language in the media is logical. The names of the majority of public, political and cultural state programs are introduced in the state language, therefore, the automation of speech skills occurs, associated with the frequency of use of these units, both among authors and readers. The use of Kazakh-language inclusions allows the reader to update various not only semantic, but also linguocultural components.

Note that even in one source there may not be a single spelling variant. The mutual influence of the two languages is expressed in spelling and pronunciation variants, which we observe when trying to convey in writing the proper names (for example, geographical names, people's names):

TheGLK construction project Kok Zhailau can be changed. 
The developer of the project "Kok Zhailau" answered the opponents of the construction site.

I have already said in one of the interviews that many so-calleddefenders Kokzhailau in fact, first of all, defend their privilege in using the plateau's nature in a narrow circle [Nur.kz05.15.2018,].

The same news in Kazprade: Tokayev supported the decision to postpone the construction of "Kek Zhailau"

Another example of the transfer of a proper name in the same material: "You know Lyuzt Muratovna as a wellknown journalist, a qualified television specialist and a good top manager," the minister wrote.

Tanysbai Lyazzat Muratovna was born on October 11, 1973 in the East Kazakhstan region, in the village of Urdzhar [Kazpravda, 08.04.2019].

As you can see, there is a mixture of the graphic appearance of the word. In the same text there can be several spellings: with and without a hyphen, in Russian and Kazakh languages, and also in Kazakh with errors as a reflection of the phenomenon of interference. The last example in the expression of the author's intention is indicative: a graphically highlighted combination of name and patronymic in two languages.

There is a connection with the method of obtaining information by the author: written (press release) or oral (direct speech, interview). When the written version of the official message adhere to the version of the Kazakh graphics, make fewer mistakes.

In the selection of words-impregnations, their nature and the way of presentation in Kazakhstan's media discourse, the features of intercultural communication of Kazakhstan are traced: as the collected and presented material shows, the authors in most cases try to make an explanation in the text, commenting on which the success of communication depends detect and not oppose their linguistic and cultural difference, do not distance themselves from the reader.

We can single out the following natural conditions for the use of Kazakh-speaking inclusions: firstly, the need for the nomination of state realities, secondly, the possibility of imparting special expressiveness and expressiveness to the text, using the entire communicative and pragmatic potential of a foreign language word. Of course, not all journalistic and informational materials are saturated with Kazakh inclusions, but still they are quite common and quite recognizable in such mass media resources as " ", "Sputnik", "Karavan", "Kazpravda", Express-K and others.

Interesting remark Novozhenova Z.L. that an important role in the use of foreign-language inclusions is also played by such factors as language fashion, which is a complex social and speech phenomenon [10, p.39]. Thus, the change in the status of Kazakh-speaking inclusions in modern texts of journalism is due to processes within the state: a change in the status of the contacted languages, the strengthening of intercultural relations, the expansion of the influence of Kazakh culture, and the intensification of information exchange.

Meanwhile, it is difficult to trace any strict pattern in their use. Probably, the choice of these words was decisive factor in their communicative relevance. The peculiarity of media texts is formed by a combination of scientific knowledge, the official state nomenclature, terminology and everyday speech, which creates a unique system of imaginative perception of the world. This combination is due to the focus on the widest possible coverage of the readership.

It should be concluded that the appearance in the media texts of Kazakh-speaking inclusions is due to the following reasons, firstly, from the knowledge of the speaker or writing subject of another language, in this case Kazakh; secondly, from the pragmatic intentions, intentions of the author, those communicative goals that he sets for himself. Also on the active use of inclusions affects a complex of external causes of the linguistic and cultural level: the type of text, its genre and stylistic characteristics; the nature of contacts between 
languages; intensity of cultural contacts between native speakers.

\section{References}

Leontiev A.A. Foreign language blotches in Russian speech // Questions of the culture of speech. - 1966. №7. - p. 60-68.

Krysin L.P. The Russian word, one's own and someone else's: A study of modern Russian language and sociolinguistics. - M .: Languages of Slavic culture, 2004. - P.59-64.

Listrova-Pravda Yu.T. Foreign language blotches-biblism in Russian literary speech XIX-XX centuries. // Bulletin of the Voronezh State University. Ser. 1. - 2001. - № 1. - p. 119-139.

Nikolaev S.G. Phenomenology of bilingualism in the works of Russian poets: dissertation dissertation. ... Dr. Phil. sciences. - Rostov n / a, 2006. - 46s.

Klushina N. I. Communicative stylistics of journalistic text // World of the Russian word. - №4. - 2008. - p. $67-70$.

Kozhevnikova MA. Artistic multilingualism in the language of the writer of the emigrant B. Khazanov: dissertation for the degree of Candidate of Philological Sciences. - Krasnoyarsk, 2016. - 201s.

Manina S.I. Foreign inclusions in the aspect of pragmatics // Cultural life of the South of Russia. - 2008. - №2. - P.141-143.

Norlusenyan V.S., Grigorieva N.O. Foreign language blotches in the modern artistic text: communicativepragmatic potential. - Philological issues, 2014. - p. 75-82.

There are no legal and legal conditions. - Barnaul, 2000. - P.46-55.

Novozhenova Z. L. Foreign Intersperses as a Discursive Phenomenon: Russian Word in a Strange Text // Bulletin of the Baltic Federal University. I. Kant. - Series: Philology, pedagogy, psychology, 2012. - №8 - P. $37-42$. 
Social Sciences: Achievements and Prospects Journal 4(12), 2019

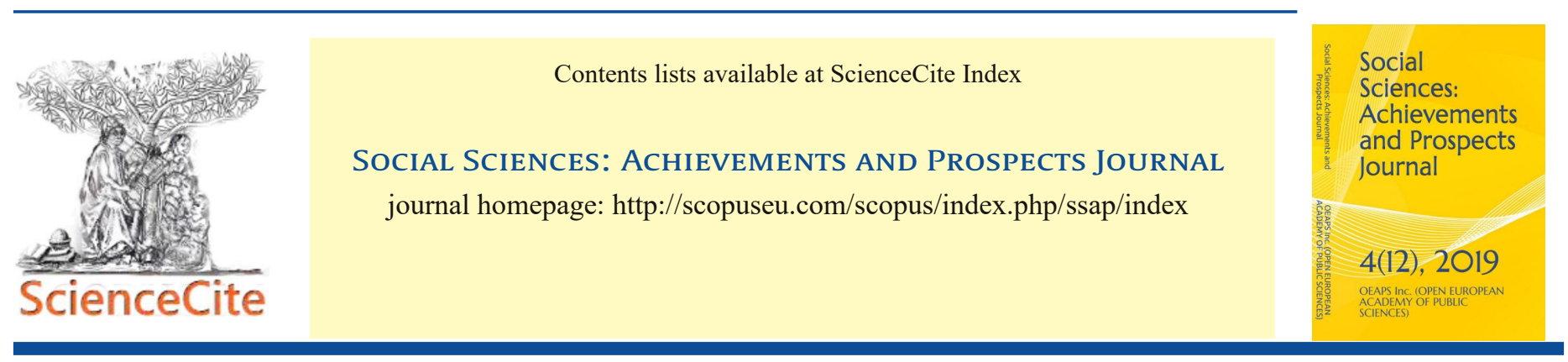

\section{DISTANCE EDUCATION IN THE CONTEXT OF GLOBALIZATION: PROBLEMS, SEARCH FOR A SOLUTION}

\section{Sharakpaeva Gulnar Dmitrievna}

Almaty University of Power Engineering and Telecommunications,

Candidate of Philosophy Sciences, Associate Professor, Department of Spiritual and Physical Education

\section{Manankova Olga Alexandrovna}

Almaty University of Power Engineering and Telecommunications

Master of Technical Sciences, Department of Spiritual and Physical Education

\begin{tabular}{|c|c|}
\hline ARTICLE INFO & ABSTRACT \\
\hline Article history: & The article deals with the analysis of distance education in the modern \\
\hline 07 May 2019 & globalization, as well as the problems and difficulties faced by teachers \\
\hline Accepted & and students in the process of this form of training. Distance learning \\
\hline Available online 16 May 2019 & system provides an excellent opportunity for higher education to those \\
\hline Keywords: & who did not have or want to get a second education with the aim of \\
\hline $\begin{array}{l}\text { Education, } \\
\text { globalization, } \\
\text { knowledge, }\end{array}$ & $\begin{array}{l}\text { needs. This article, highlighting some of the difficulties and problems } \\
\text { of training in modern globalization, can help teachers to allow and } \\
\text { overcome some of these new problems. }\end{array}$ \\
\hline
\end{tabular}

educational process

(c) 2019 The Author. Published by OEAPS Inc. This is an open access article under the CC BY-NC-ND license (http://creativecommons.org/licenses/by-nc-nd/4.0/).

\footnotetext{
* Corresponding author. E-mail address: jeunne15@mail.ru 
The information revolution of our century has a great influence on all spheres of social life of modern man, including the education system. Communication technologies allowed to reduce the time to receive education and helped to overcome the barriers of national and regional boundaries. As a consequence of the emergence of a number of new educational environments, particularly within the framework of remote education. Distance learning is a type of learning, based on the educational interaction remote from other teachers and students. This training is using telecommunication technologies and network resources within the Internet space. It has several models. Including the integration model classroom and distance learning in various proportions. Thanks to the efficiency of distance learning has a number of differences from face-to-face and correspondence courses. For example, a part-time student, studying the learning materials independently, can ask teachers only two or three times a year during a session, and during distance learning he has constant contact with a teaching instructor. For this purpose, a specially created training server is used, which allows you to communicate with the teacher, colleagues and control the success of learning the material. Each "distance" student is attached to a tutor and administrator who perform the following tasks: supervise training, advise on complex topics and questions, check tests and tests, help prepare for exams.In the correspondence course, the rate of learning is fixed and uniform for the whole group, and during distance learning, each student has the opportunity to devote more time to more complex and important topics. It should be borne in mind that for each completed section of the course the student must report to the teacher in certain periods, passing test assignments or tests. The distance learning system provides an opportunity to get higher education for those who have completed secondary or specialized secondary education, as well as for those who have incomplete higher education and, finally, for those who already have a higher education. So, the globalization of distance education provides ample opportunities for those who want to improve their professional skills by solving the following tasks: 1) expanded access to educational and training facilities, which opens up the possibility of obtaining a diploma of education abroad, without leaving their country.

Developing countries with limited educational resources are gaining access to global training facilities to complement and improve their efforts to provide education to a large number of people. Satellite technologies are widely used by developed countries to transfer their educational programs to remote parts of the world. In the context of globalization, there is a great need for obtaining knowledge in the technical and information fields; 2) training using already accumulated experience and knowledge. Thanks to modern communication technologies, there is an easy access to information sources, educational material, which contributes to obtaining education using the rich study experience of other students and their accumulated knowledge.

The various methods that are used by distance education institutions are easily accessible through an accumulated database. Globalization, in this sense, contributes to the process of acquiring knowledge, using existing experience and practice; 3) mutually beneficial partnership between the participants of the educational space contributes to the rapid provision of educational services that go far beyond the specific institution or institution. Partnership agreements contribute to the improvement of educational material, which is the basis in distance learning. Cooperation between distance learning institutions takes a variety of forms, including such as: joint distribution of courses and training programs, certification programs and distribution of the above programs with the help of a collaborating institution; 4) a competitive environment based on expanded access to educational material may influence the enhancement of the profitability process between educational institutions for the provision of educational services. Distance learning is characterized by all components of 
the system of ordinary education, namely: the meaning, content, goals, organizational forms, means of education, the system of control and evaluation of the results of the knowledge gained. At the same time, there are no territorial boundaries for this form of education, but there is one most important condition, namely the possibility of access to Internet resources for work on the training server. The technology platform for distance education consists of e-mail, distance learning courses, video conferencing, forums, etc. The flexibility of the educational process makes it easy to combine work with training, which opens up personal growth opportunities along the career ladder or contributes to the development of your own business. Students enrolled in distance learning programs acquire the skills to work with the latest technologies, receive specific knowledge on the processing and assimilation of educational information for its correct use. Along with the advantages of distance learning, there are a number of drawbacks, we would like to draw attention to some of them and make them the object of analysis in this article. Some researchers in the field of education believe that the paradox of globalization is that it gives a strong impetus to the localization process. "It is important to note that in modern conditions" global education "unites various educational systems, differing in their historical, philosophical, cultural traditions, declaring in various ways their attitude to" global education ", but actively using its capabilities for their own purposes." (1) The development of the necessary programs and necessary materials for the distance learning system, which would be universal for all countries and different regions of the world, is an absolutely impossible task. Creating an optimal training course for an international learning environment is a rather complex and crucial cognitive problem. It is even more difficult to develop educational materials for a particular cultural environment so that it fits a different cultural environment. To follow the general methodological and target setting in education, and it is such that knowledge must be clear and specific, it is necessary to take into account national and regional features of accreditation of the student audience. Only in this case, programs designed for global distance education will be relevant in all respects. Localization of educational material in this sense emphasizes the importance of taking into account the susceptibility of the cultural environment for which they are prepared. In the context of globalization, educational materials and their delivery systems should be built taking into account the diversity of cultures. Accordingly, student needs can also vary greatly. A global distance teacher must think globally, but act locally. Gaining momentum and traced another, the opposite tendency, to think locally, and act globally. We want to draw attention to the indisputable fact that if a teacher is in demand that the results of his activities on the labor market, he must take into account the cultural characteristics of his students. Problems that arise in distance education abroad include: various attitudes regarding the duration and form of a course of study, the use of language, the use of teaching methods unusual for a foreign country, communication technologies, forms of student support, cultural specificity of materials.In addition to all this, the problem of cultural imperialism remains relevant - the risk that foreign educational materials, especially when they are distributed from industrial to developing countries, will be viewed as an attempt to establish the influence of a strong foreign culture.

This is not only an international issue: the same problem arises at the local, interregional level. In a broad sense, globalization involves the use of world resources for the development of mankind. It is intended to promote the creation of partnership agreements for the unification of all the resources of the planet in order to realize a common vision of the "one world". 
An alternative possibility is that benefits can be gained from the process of globalization, due to the fact that countries can attract more resources to create and use market demand in developing countries with the ultimate goal of making more profit. This profit-making opportunity based on partnership agreements may distort the social priorities of education.In this situation, the incentive for the conclusion of international cooperation agreements on the part of developed countries will be profit-making, and on the part of developing countries the opportunity for "theoretical teachers" to visit developed foreign powers. Agreements about cooperation in a situation of unfair competition are unlikely to bring significant benefits to students in developing countries.Despite the fact that today information channels provide an opportunity for global transfer of knowledge, developing countries are still not provided with appropriately needed export goods (knowledge) and means of transmission (technology) in order to use information superhighways. Outdated telecommunications systems, the high cost of connections, low all educational institutions, the level of technical knowledge and bureaucratic obstacles often limit the ability of countries such as India, for example, to actively participate in the global implementation of distance education programs. The inability to use modern communication systems and, as a result, the lag in communications is one of the problems that IGNOU faces when implementing its programs in developed countries. Despite the broad prospects and great opportunities, experts agree that the DG system can not be called ideal.Working with virtual students, it is very difficult to verify who ultimately performs the work. In Western countries, almost all educational institutions that practice DG have representations or authorized persons in each town or state, which are obliged to testify that the exam was passed by the person who was declared.n our country, such a system is just beginning to develop, and this limits the possibilities of using fully interactive distance learning. In order to at least make sure that the diploma is received by the person who passed the exams remotely and performed the work independently, in most training centers face-to-face sessions and group exams are held in computer classes to test residual knowledge.Distance education is becoming important in Kazakhstan. The strategic direction of the "State Program for the Development of Education of the Republic of Kazakhstan for 20052010 " defines the entry of the education system of our state into the European and world educational space. In accordance with this, the priority task is the informatization of education at all levels of the educational environment and the introduction of new learning technologies. This approach is justified, above all, by the processes of globalization that have affected the whole world today. In many ways, the complex and prospective development of Kazakhstan, as well as the current opportunity to occupy a worthy place in the global labor market of specialists from our state, depends on solving the problem of informatization of the entire education system and the main spheres of life of the modern Kazakhstani person.Currently, Kazakhstan is carrying out a whole range of high-tech pedagogical projects aimed at implementing the state program of informatization of education. Among them are distance learning in rural schools, electronic textbooks, electronic methodical systems in subject areas of knowledge, electronic vocational guidance work, informatization of the education management system, and Internet schools.Information and telecommunication technologies of open distance learning allow you to modify the nature of the development, acquisition and dissemination of knowledge, open up opportunities for updating training content and teaching methods and methods, and expand access to any level of education. The study and analysis of materials of international, republican, regional scientific and practical conferences related to modern educational technologies, allows us to conclude that today the problem of introducing distance education in Kazakhstan is of concern to specialists of a wide variety of different fields. It is not enough to simply follow world educational trends and development standards, and it is important and necessary to also create the necessary 
opportunities so that these trends can be realized in the conditions of modern Kazakhstan. This is a common and most important problem faced by developing countries in the context of the globalization of distance education, especially in the context of uneven world development. "Thus, education, having as its main goal, the creation of a holistic person, must itself become holistic, that is, constitute an inseparable dialectical unity of preservation and development.In addition, all directions of development of modern education, whether it is traditionalism or modernization, should be morally and spiritually comprehended, that is, lead to the spiritualization of education, and it, in turn, should contribute to the spiritualization of the whole social integrity."

List of literature:

1. Kamashev S.V., Kosenko T.S. Globalization of education and "global education" in the modern world // Philosophy of Education - 2012, -№ 6 (45) .- S., 132. 2.

2.Mironova N. V. Education in the context of Globalization. Philosophy of Education-2012,- №6 (45).-C.5256.

3. Frolov, I.T. Introduction to philosophy (Text) / I.T. Frolov.- M .: Politizdat- M., 1989-367c.

4. Alekseev, P.V. Theory of Knowledge and Dialectics (Text) / P.V. Alekseev.- M. Higher. mk-M.1998-383s. 
Social Sciences: Achievements and Prospects Journal 4(12), 2019

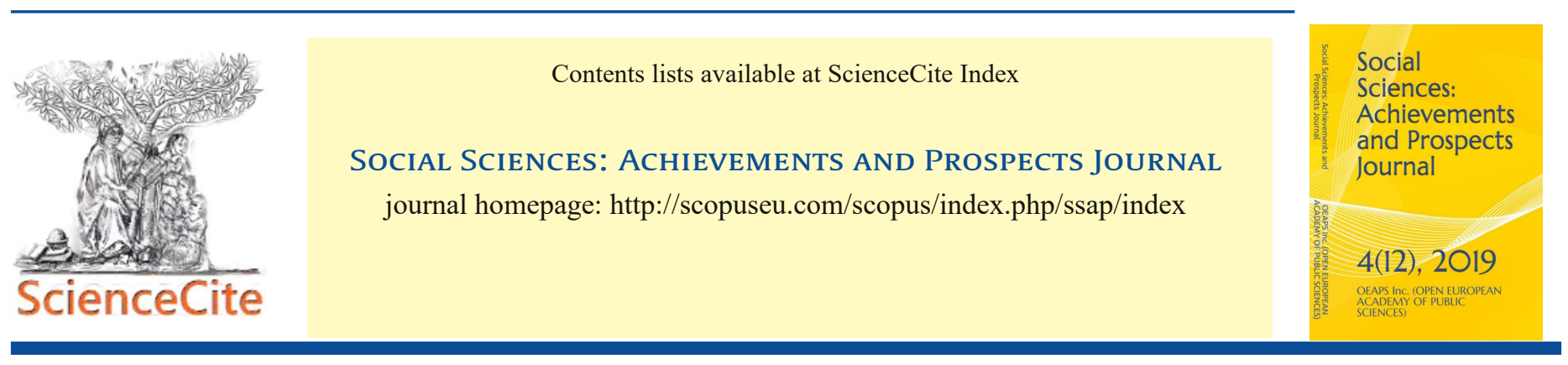

\section{INTERNET-BASED PROJECT WORK}

\section{Polyak Dina Mironovna}

Almaty University of Power Engineering and Telecommunications, Associate Professor, Candidate of Philological Sciences,

Department of Language Competence Development

\section{Erzhanova Zhanna Borisovna}

Almaty University of Power Engineering and Telecommunications

Senior lecturer, Department of Language Competence Development

\section{ARTICLE INFO}

Article history:

Received

Accepted

07 May 2019

Available online 16 May 2019

\section{Keywords:}

Website, Internet, technology, videoconferencing sessions, multimedia materials, Internet-based simulations, Webquests

\section{ABSTRACT}

Some words about attitudes to technology: many people are afraid of new technology and, with the increasing presence of the Internet and computers, the term technophobe has appeared to refer to those of us who might be wary of these new developments. More recently, the term digital native has been coined to refer to someone who grows up using technology, and who thus feels comfortable and confident with it there is a tendency to call computer users either technophobes or technogeeks ( a term for a technology enthusiast) the truth is that most of us probably fall somewhere between the two extremes. A large part of the negative attitudes teachers have towards technology is usually the result of a lack of confidence, a lack of facilities or a lack of training, resulting in an inability to see the benefit of using technologies in the classroom. It is also often the case that teachers may not be fully in control of their work situations. A teacher may want to use more technology in their teaching, but the school may not have the facilities, or, on the other hand, a teacher may be instructed to start using technology for which they feel unprepared or untrained.

(c) 2019 The Author. Published by OEAPS Inc. This is an open access article under the CC BY-NC-ND license (http://creativecommons.org/licenses/by-nc-nd/4.0/). 
Planning lessons using the Internet: planning a web-based lesson, rather than one where the web content plays an ancillary role, is not intrinsically different from planning a more traditional one. We like to divide a typical web-based session into three parts (www): warmer, web, what next. The warmer part of the lesson is the kind of thing we all do as a matter of course, with introductory activities, interest-generating ideas, and so on. This part prepares your learners for what they are going to be doing in the web part of the lesson. Our view is that this part of the lesson is best done in the familiar environment of the normal classroom. In the web section of the lesson, it's important to spend only as much time as you need working with the computers. We prefer to take learners to a computer room for this part rather than spend the entire class in there. This has the double advantage of allowing more groups to use the room and of keeping learners focused during their time there. It is also an opportunity for learners to stretch their legs and provides a change of pace. On the other hand, moving from the traditional classroom to a computer room does have the potential to disrupt your class, so careful planning of the logistics may be necessary. If you have limited access to computers, or perhaps only one computer in the classroom, you can print off the web-based materials you want to use with your learners in advance, and simply use a print version. This is, of course, not as exciting as using computers themselves, but can bring the Internet into more resource-poor environments. Of course, there are certain teaching situations where teachers are obliged to take their learners to a computer facility for one or more lessons per week. If you do find yourself in this position, you can adapt your lesson plans to make greater use of the Internet than we are suggesting here. You may even choose to incorporate the use of websites more consistently into the curriculum of the course you are teaching - perhaps substituting a part of the course materials you are using for websites, for example the reading texts or the listening material. However you decide to do this, it must be a transparent process for the learners, and they must be able to appreciate not only the thought processes that have gone into this decision, but also the relevance and value of the change. This can be achieved in part by helping learners to cast a critical eye over the materials they work with in class, and encouraging them to talk about what they like doing and what they don't. It should also be born in mind that your learners will have favourite websites of their own, and it is well worth investigating whether these can be incorporated into your classroom teaching, partly as a motivator, but also as a link to their lives, interests and experiences outside the class. This again will help them to see the value of the technology applied in class. It's worth remembering that once you put people behind computer monitors, it's easy for them to forget that you are there, and - more importantly - why they are there. So the two vital words here are time and task. Make sure your learners have a clearly-defined task to achieve and a clearly-defined time frame in which to achieve it. Once the group has got what you intended from the computers, it's time to move them back to the classroom for the what next stage of the lesson. This part should deal with the tasks set for the web part and then proceed with more familiar follow-up activities to round off the lesson.

Using websites is one of the easiest and least stressful ways of getting started with technology in the classroom. There is a large and constantly expanding collection of resources on the web, at a variety of levels and covering an amazing array of topics. You can choose from authentic (written for Internet surfers in general) sources or Ell-specific sites (made by, and for, teachers), monolingual or multilingual sites, sites with multimedia, or just simple text, for those on slower connections.

The web is a source of content which can be used as a window on the wider world outside your class, and is of course - a readily available collection of authentic material. As such, it is a much larger repository of content than would previously have been readily available to you and your students. 
The technology needed to use the Internet for teaching is relatively limited and the chances of something going wrong are greatly reduced over more complex technology approaches such as attempting to carry out live chat or video-conferencing sessions.

Another advantage of this tool is that you don't necessarily have to rely on a constant Internet connection if you bear in mind that it is possible to save local copies of websites on your computer, or print out potentially useful pages for later use.

It's important that both you and your learners see the use of the Internet as an intrinsic part of the learning process, rather than as an occasional activity which has nothing to do with their regular study program. We would therefore recommend that, if you plan to use the Internet, you should talk to your learners and explore the reasons for using this resource with them. This can be done at lower levels in their own language or in English with higher-level classes. You will need to talk to your learners about why Internet content may be useful to them and discuss their attitudes to technology in general - when they use computers, and what for. Show them how the coursebook and other materials can be enhanced by extra material from the Internet, but above all, make it clear that this is not a toy, not something that you are just using to fill in the time. [1]

With some learners there may be some resistance to regular computer use in, the classroom. We have often found, for example, that professional people view computers as work tools rather than as resources for learning. It is vital that they appreciate that this is a useful, as well as an entertaining, tool in the classroom and that it can contribute to their language development in a variety of ways, for example by giving them the opportunity to build vocabulary or improve their listening skills. Lower-level classes can be engaged with visual and multimedia materials, the use of songs and other video materials.

How to find useful websites? As already mentioned, the Internet is a vast repository of information and resources, and it is perhaps exactly this range that makes it seem, at first, daunting and unapproachable to most teachers. In the following two sections we take a look at how to find and evaluate resources for use in class.

The ability to search through Internet content, and quickly and efficiently find suitable resources is perhaps the most underrated, and yet most useful, skill that both teachers and learners can acquire.

For teachers, having good search skills means finding useful resources quickly, speeding up lesson planning and facilitating web use in class. For learners, it means being able to quickly accomplish web-based tasks, thus ensuring that the technology enhances the learning experience rather than impeding it. It makes sense then, both to acquire these skills, and to spend some time sharing them with your learners.

A natural progression from using individual web pages and websites in the classroom is to move on to online project work. There are many compelling reasons for using Internet-based projects in the classroom:

-They are a structured way for teachers to begin to incorporate the Internet into he language classroom on both a short-term and a long-term basis. No specialist technical knowledge is needed either to produce or to use Internet-based projects. However, it is certainly true that they will take time to plan and design, so it is well 
worth looking around on the Internet to see if something appropriate already exists before sitting down to create your own project.

-More often than not, they are group activities and, as a result, lend themselves to communication and the sharing of knowledge, two principal goals of language teaching itself. The use of projects encourages cooperative learning, and therefore stimulates interaction.

-They can be used simply for language learning purposes, but can also be interdisciplinary, allowing for crossover into other departments and subject areas. This can often give them a more 'real-world' look and feel, and provide greater motivation for the learner.

-They encourage critical thinking skills. Learners are not required to simply regurgitate information they find, but have to transform that information in order to achieve a given task. [2]

In the context of doing project work, the Internet can be thought of as an enormous encyclopedia because it gives our learners quick access to a wealth of information which they can use to carry out their project tasks. A good example of such a source is Wikipedia (www.wikipedia.org), a collaborative encyclopedia produced by and for the Internet community. Wikipedia has thousands of articles on many different subjects, and is an ideal place to start when doing project work that requires factual information about people and places.

Project work online can range from a simple low-level project like making a poster presentation about a famous person to high-level investigative work where learners research a subject and present polemical views and opinions in a report or debate. In order to prepare for Internet-based project work, you will need to do the following:

Choose the project topic. Will your learners be researching famous people, an event or an issue?

Make the task clear. What information will they need to find - biographical, factual, views and opinions?

Find the resources. Which websites will your learners need to visit? Do these websites contain the information they need and are they at the right level?

Decide on the outcome. What is the final purpose of the project? For example, will your learners be making a poster, a presentation or holding a debate?

Internet-based simulations. Internet-based simulations bring real-life contexts to the classroom helping our learners to deal with situations that they may come across during foreign travel or in encounters with other speakers of English. The more traditional approach has teachers cutting up prepared role-cards in order to simulate these contexts. The Internet largely does away with this approach giving learners access to authentic websites that provide stimulating and relevant content that enables them to carry out these simulations. Simulations like these work particularly well in the field of business English, where the language learning is very task-or goal-oriented, but they also work well with general English learners who may have less clearly 
defined reasons for using English ,as we will see below. [3]

A business English simulation can be described the following way. This sample simulation looks at the case of a personal assistant having to organize their manager's business trip to the United Kingdom. The benefit of this kind of simulation is that it uses real websites and a potentially real situation, to further the learner's reading, information processing planning and communication skills. As an additional benefit, it also addresses technology skills that are useful in this professional context.

Of course, a busy teacher is not going to prepare complex simulations such as this on a daily basis, but for occasional activities they really can bring home not only how useful the Internet is for busy professional people, but can also be an important confidence booster for learners. Working through carefully guided but complex tasks such as these - tasks which have a direct relation to what they do in their work - can reinforce the value of their language classes and keep motivation high. In this particular simulation, we take the case of a learner who communicates primarily in the written form, using letters, faxes and emails. It is this factor that influences the nature of the tasks in the simulation.

What are Webquests? Webquests are mini-projects in which a large percentage of the input and material is supplied from the Internet. Webquests can be teacher-made or learner-made, depending on the learning activity the teacher decides on. What makes webquests different from projects or simulations is the fairly rigid structure they have evolved over the years, and it is this structure - and the process of implementing webquests in the classroom - that we will be exploring here. Bernie Dodge, a Professor of Educational Technology at San Diego State University, was one of the first people to attempt to define and structure this kind of learning activity. According to him, a webquest is 'an inquiry-oriented activity in which some or all of the information that learners interact with comes from resources on the Internet'. He goes on to identify two types of webquest:

-Short-term webquests. At the end of a short-term webquest, a learner will have grappled with a significant amount of new information and made sense of it. A short-termwebquest may spread over a period of a couple of classes or so, and will involve learners in visiting a selection of sites to find information, and using that information in class to achieve a set of learning aims.

-Longer-term webquests. After completing a longer-term webquest, a learner will have analyzed a body of knowledge deeply, transforming it in some way. They will have demonstrated an understanding of the material by creating something that others can respond to, online or offline. This is the big difference between the longer-term and short-term webquests - learners have to transform the information they acquire, turning it into a new product: a report, a presentation, an interview or a survey. Longer-term webquests might last a few weeks, or even a term or semester.

Webquests have now been around long enough for them to have a clearly-defined structure. However, this structure, while being unofficially recognized as the definitive schema for these activities, should only really be taken as a basic guideline and you should design your webquests to suit the needs and learning styles of your group. In the example, we will be examining an ELT webquest about responsible consumerism. It 1s designed for intermediate-level learners. 
Webquest creation can be mentioned like that. Creating a webquest does not require much detailed technical knowledge. It is relatively easy to produce a professional-looking and workable design using any modern word processor. The skillset for producing a webquest is very similar to what we explored earlier for planning Internet-based lessons, and might be defined as follows:

-Research skills. It is essential to be able to search the Internet and to quickly and accurately find resources. The best search engines currently available are Google (www.google.com) for wide searches over a large database of websites.

-Analytical skills. It is also very important to be able to cast a critical eye over the resources you do find when searching. The Internet was once described as 'vanity publishing gone mad', and it is worth bearing in mind that quality is not guaranteed. Make sure to check out any website you are considering using thoroughly before basing any activity around it. Simply because the author of a website believes elephants to be bulletproof - a real example - doesn't mean that they really are.

-Word processing skills. You will also need to be able to use a word processor to combine text, images and web links into a finished document. This particular set of skills can be acquired quickly and easily.

Before sitting down to plan a webquest it is always worth searching around on the Internet to see if someone has produced something which might fit your needs. There are plenty of webquest 'repositories', so there is little point in reinventing the wheel. Use Google to have a good look round before you do the hard work yourself - try a search for ELI webquests.

Designing for success stage can be like that. In this stage, we further structure the webquest and ensure that the learning outcomes and knowledge transformation stages are clearly delineated.

-Brainstorm transformations. This involves deciding what your learners will be doing with the information they find on the websites. Bernie Dodge identified this stage as what happens between 'learning inputs 'and' learning outcomes'. This is where you flesh out the tasks in the process stage, guiding your learners through the information they uncover, and helping them towards an understanding and transformation of that information as they work towards the products they need to put together.

-Identify real-world feedback. Learners should be engaged with the wider world when they are working with webquests. This means that you might try looking for ways in which the information necessary for the webquest might be gathered from real people-by the use of email, polls and questionnaires. This can also be 'offline', in the sense of interviewing colleagues, staff, friends and family. In our example, learners conduct a class survey on their favourite brands - and this could perhaps be extended through the school, or put online as an electronic survey, thus widening the access to the 'real world'. In a school this would involve interviewing other classes, While an online survey can quickly be put together using a tool such as Survey Monkey (www.surveymonkey.com). 
-Sort links into roles. The links you identified in the inventory resources section should now be assigned to the various sections of the process stage of your webquest, ensuring that the websites are easily navigable, understandable and contain the information that your learners need to work through the webquest. [4]

-Define the learning task. This refers to the products which are the direct result of working through the webquest. In the sample we have looked at, learners have to produce:

- a survey results of class shopping habits.

- a list of acceptable and unacceptable brands.

- a report to the class on the brands.

- a presentation of the report.

- a self-evaluation.

Now we see that the Internet can be used as an access point to real-world knowledge which our learners might lack.

The Internet can act as a springboard for authentic, relevant simulation work and as the source of materials which promote collaborative learning, communication, knowledge sharing and higher-level thinking skills.

As a result we have explored the area of motivation and considered how this can be increased with careful task design and judicious choice of Internet content, looked at the methodology for creating and using webquests.

\section{List of literature:}

1. www.bbc.co.uk.

2. www.englishcaster.com.

3. www.learn4good.com.

4. www.myspact.com. 
Social Sciences: Achievements and Prospects Journal 4(12), 2019

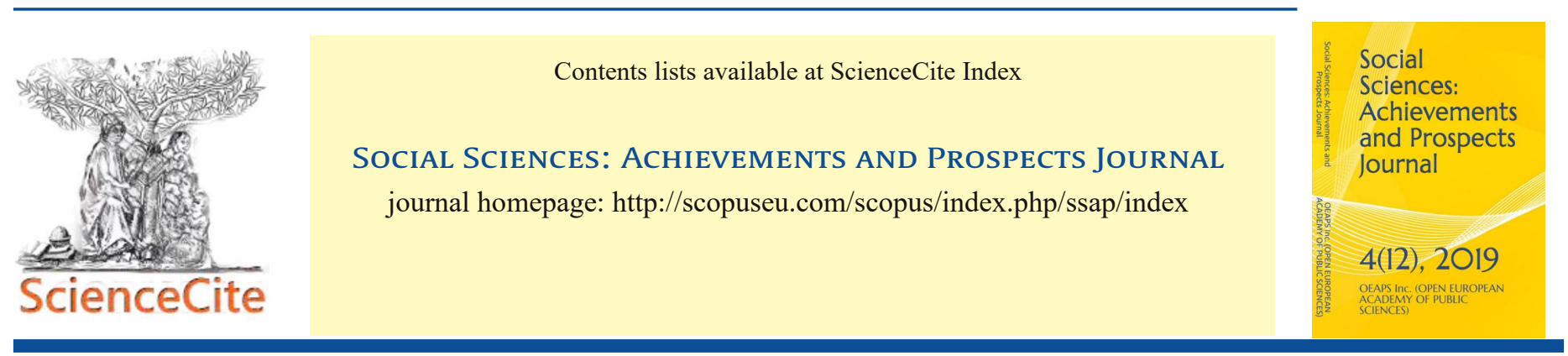

Humanizing European Paleolithic art: A new visual evidence of human/bird interactions at L'Hort de la Boquera site (Margalef de Montsant, Tarragona, Spain)

\author{
Ine's Domingo a,b,", Pilar Garci'a-Argu“ elles ${ }^{\text {b }}$, Jordi Nadal ${ }^{\text {, }}$, \\ Josep M Fullola ${ }^{\mathbf{b}}$, Jose' L. Lerma ${ }^{\text {c, Miriam Cabrelles }}{ }^{\mathrm{c}}$ \\ 'Institucio' Catalana de Recerca i Estudis Avanc, ats (ICREA), Barcelona, Spain \\ b SERP, Seccio' de Prehisto 'ria i Arqueologia, Universitat de Barcelona, Barcelona, Spain \\ c Universitat Polite 'cnica de Vale 'ncia, Departamento de Ingenieri'a Cartogra 'fica, Geodesia y Fotogrametr \\ 'a, Valencia, Spain
}

ARTICLE INFO

ABSTRACT

\section{Article history:}

Received $\quad 10$ Nov 2018

Accepted $\quad 06$ Jan 2019

Available online 10 Feb 2019

\section{Keywords:}

Palaeolithic art Portable art

Late Upper Magdalenian Crane

Anthropomorphic figures

Scenes
This paper reports the discovery of a new example of portable art in Northeastern Iberia dating to the Late Upper Palaeolithic (12.250 T $60 \mathrm{BP}$ ). The piece is analysed in relation to the European Palaeolithic art assemblage to determine its significance and how it contributes to our understandings of Palaeolithic artistic practices. Both the motifs depicted (birds and humans) and the patterns of composition (a narrative scene) are unusual in Palaeolithic assem- blages. In addition, this new find contributes to filling a geographic gap in the artistic record as evidence of Palaeolithic art is rare in Catalonia. The anatomical features of one of the birds suggest that it is a crane, a species that has been depicted in a limited number of sites, as summarized in this paper. Moreover, there are only three known example of birds and humans interacting in a narrative scene in Palaeolithic art. Exhibiting innovations in media, subject matter and compositional norms, this new find has the potential to change the classic definition of European Upper Palaeolithic art and integrate the region in the artistic trends circulating along Mediterranean Iberia during the Upper Magdalenian. 


\section{Introduction}

A new discovery at the L'Hort de la Boquera Late Upper Palaeolithic site challenges our understandings of European Palaeolithic art. The new sample of portable art presents innovations in media, subject matter and compositional norms. The 2011 fieldwork campaign at this site provided a surprising archaeological find after 14 years of continuous excavations: the first and so far only piece of portable art from the site and one of the few examples unearthed in North-eastern Iberia (Fullola et al., 2015; Garc1'a-Diez and Vaquero, 2015, 2006; Garci'a-Diez, 2004). The find includes five engraved motifs. The interpretation of one of them as a quite naturalistic bird and another as a human is secure when compared to other European Palaeolithic depictions of similar subject matter (Cremades, 1994; Cremades et al., 1997; Duhard, 1996). However, the remaining figures are simplified and their identification requires the analysis of previous representations of scenes in Palaeolithic art and the ethology of species represented. The identification of the bird species as a crane is based on biological similarities between the motif engraved and the living specimens of this species (Peterson et al., 1967; Meine and Archibald, 1996), as well as in a comparison with previous representations identified as cranes in European Palaeolithic art (Cremades, 1997; Cremades et al., 1997; Simonnet, 1947; Capitan et al., 1909). The originality of the new piece rests not only on the unusual motifs engraved, birds and anthropomorphic figures, but also in their patterns of association. The motifs integrate a very neat narrative scene lacking the tangle of strokes that characterise a significant number of portable Palaeolithic artworks.

This paper analyses this single example of portable art and the archaeological context in which it was recovered. It also assesses the significance of this find in terms of both the regional and global contexts of European Palaeolithic art, where representations of birds (Cremades, 1994; Nicolau- Guillaumet, 2008), humans (Duhard, 1996) and narrative scenes are unusual. The new discovery provides a well contextualized example of Late Upper Magdalenian art and enriches the meagre record of European Palaeolithic art in Northeastern Iberia and more broadly.

\section{The archaeological context}

L'Hort de la Boquera site is located in Margalef de Montsant (Tarragona, Spain) (Fig. 1), at $384 \mathrm{~m}$ a.s.l. and only $34 \mathrm{~km}$ away from the current coastline. Montsant massif, with an altitude of $1000 \mathrm{~m}$, separates it from the sea. The site appears in a $9 \mathrm{~m}$ long rock shelter. The original conglomerate overhang was partially destroyed by a combination of heat and natural disaggregation (fragments of conglomerate are visible in the final stages of level II), leaving part of the deposits uncovered. 

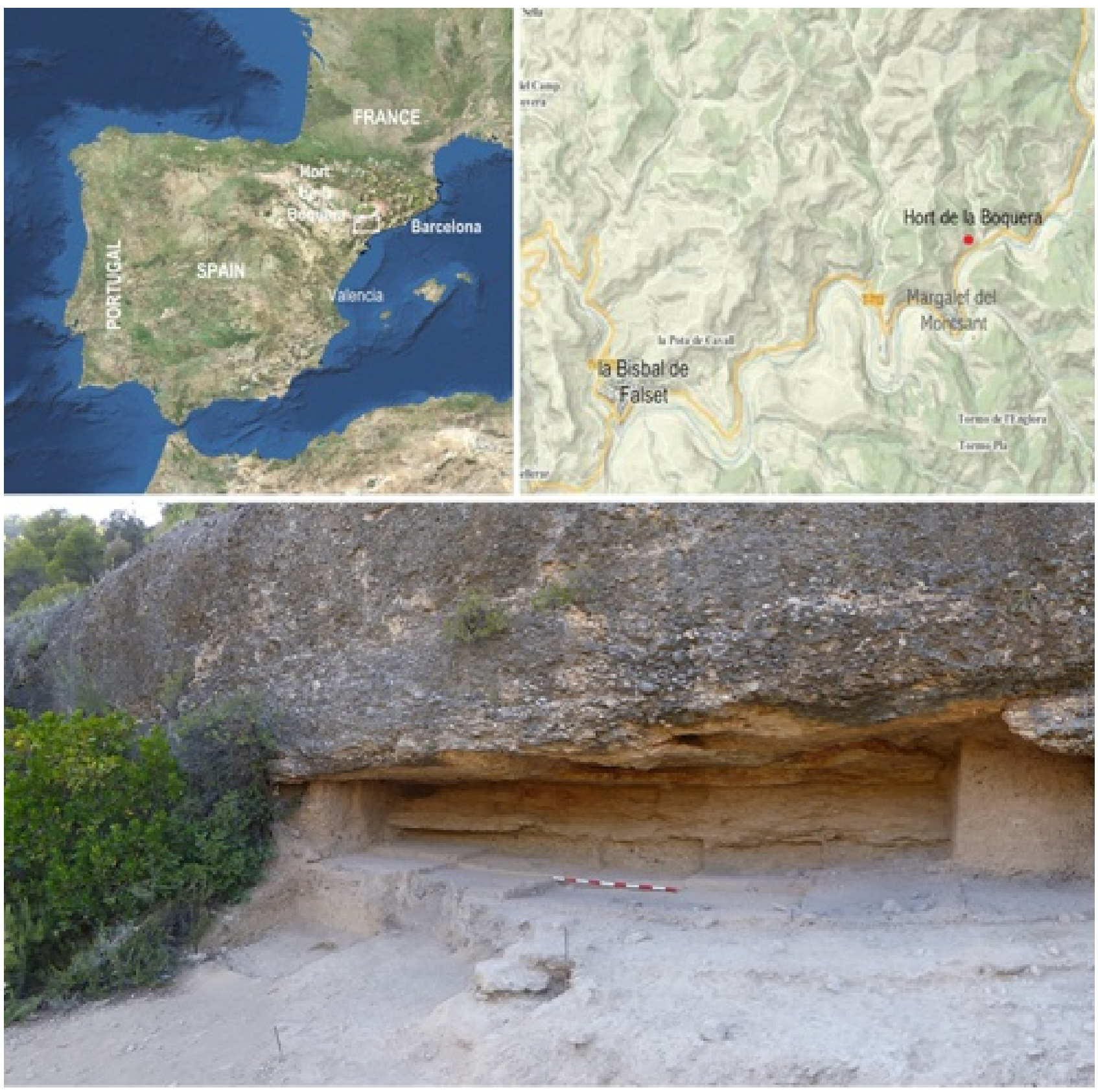

Fig. 1. Site location. Satellite photo and map of the Institut Cartogra` fic i Geolo` gic de Catalunya (http:// www.icgc.cat/) with labels by the authors. Photograph by P. Garci'a-Argu“ elles.

Localisation du site. Photo satellite et carte de l'Institut Cartographique et Ge'ologique de Catalogne (http:// www.icgc.cat/) avec les e'tiquettes des auteurs. Photos de P. Garc1'a-Argu“elles. 


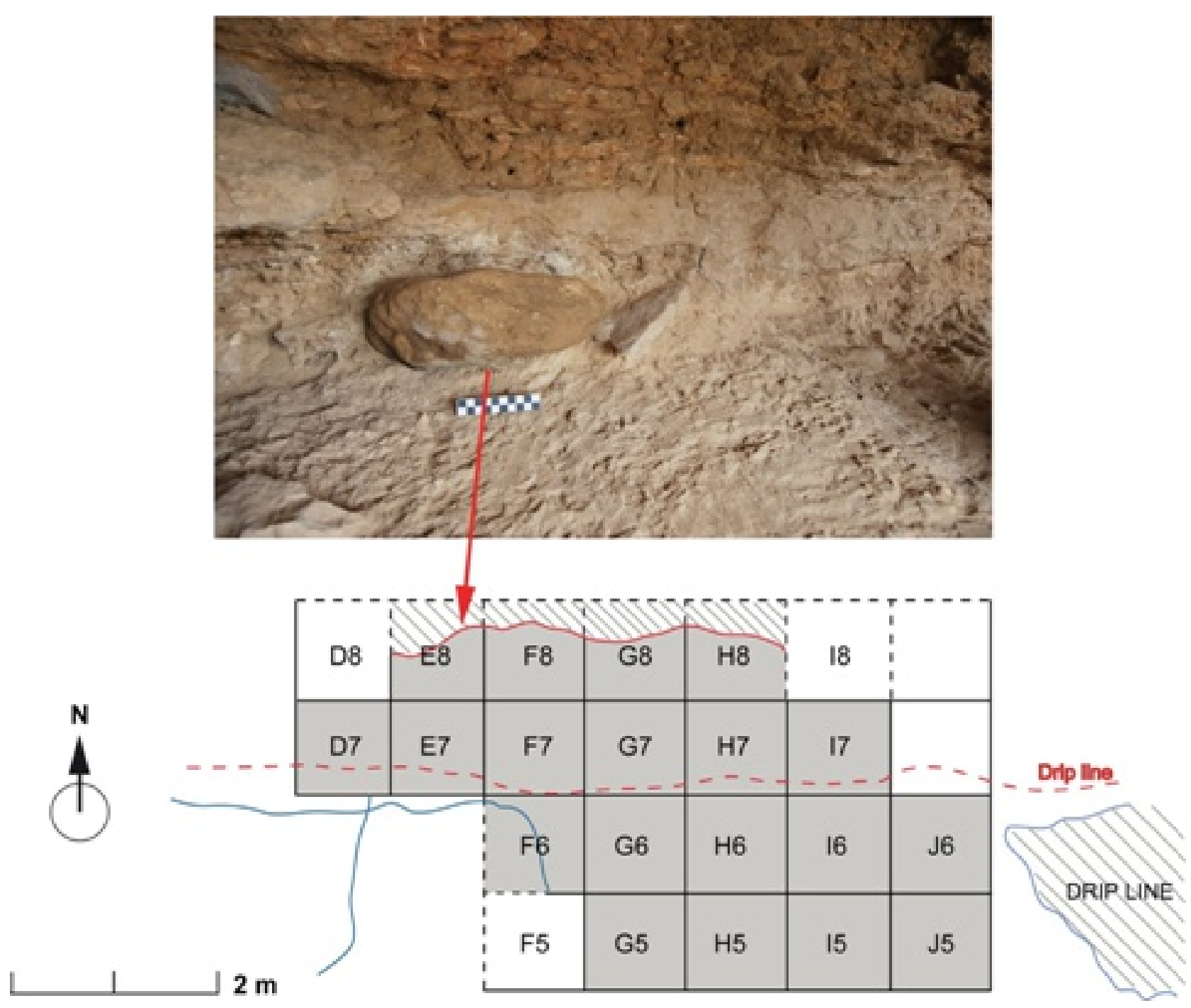

Fig. 2. Site plan indicating the location of the artwork, and photograph illustrating the position at the time of discovery.

Plan du site indiquant l'emplacement du bloc grave' et photographie montrant sa position au moment de sa de 'couverte.

The site was discovered in 1979 during an archaeological survey (Garci'a-Argu“ elles et al., 2014). The chronology has been slowly clarified through an initial trial excavation of a trench (Fullola, 1978), subsequent research projects (Garc1'a-Argu“ elles, 1983; Bergada', 1998) and, since 1998, an uninterrupted open-area excavation exposing $22 \mathrm{~m} 2$ (Garc1'a-Argu“ elles et al., 2014). It preserves four stratigraphic levels with a unique archaeological deposit (Level II) resulting from several human occupations related to a single cultural entity. This level includes two hearths and several knapping areas. Several radiocarbon dates place the site in the Late Upper Magdalenian (dates on charcoal: OxA- 13595: 12.250 T 60 BP, OxA-23646: 11.850 T 45 BP and OxA-23645: 11.775 T 45 BP, which calibrated become 14.350 T 230 cal 
$\mathrm{BP}, 13.710 \mathrm{~T} 70 \mathrm{cal} \mathrm{BP}$ and $13.670 \mathrm{~T} 60 \mathrm{cal} \mathrm{BP})$. This dating is also supported by the characteristics of the lithic assemblage (Garc1'a-Argu“ elles et al., 2014). From an economic point of view the site fits well within the Late Upper Magdalenian sites located in areas of rough topography, and focusing on Spanish Ibex (Capra pyrenaica) hunting, with scarce remains of rabbits and no evidence of birds. These sites differ from those located in lower hills that focus on deer hunting (Fullola et al., 2012). The art piece under study was discovered when digging grid square E8, corresponding to the earliest occupation of the site (in clear association with radiocarbon date $12.250 \mathrm{~T} 60 \mathrm{BP}$ ) (Fig. 2). The piece was almost in contact with the back wall of the rock shelter. It was completely covered in mud with the decorated surface facing down.
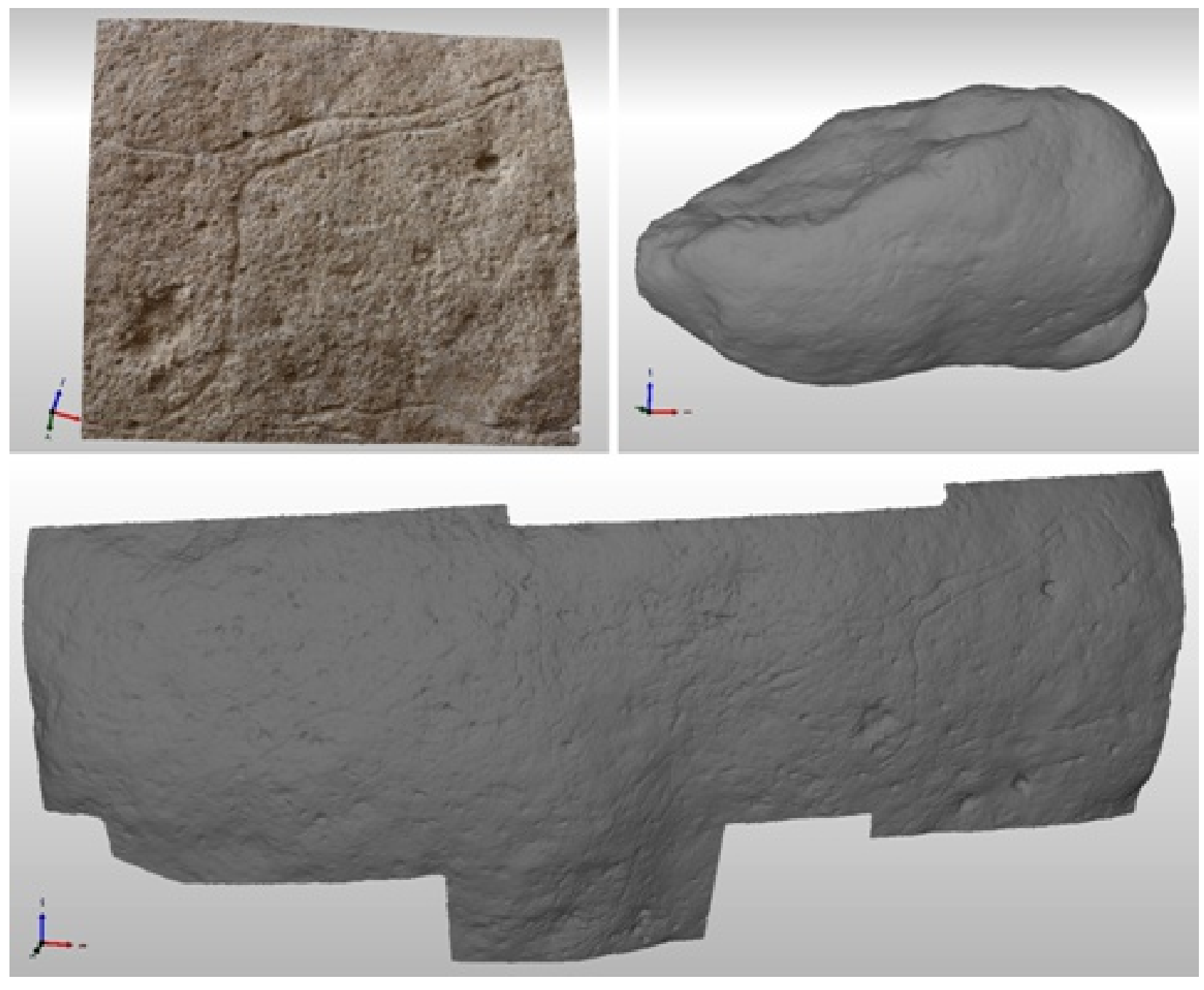

Fig. 3. 3D digital recording of the artwork: a: detail of the high-resolution point cloud; b: low-resolution 3D model; c: high- resolution 3D model.

Enregistrement nume'rique 3D du bloc grave' : a : de'tail du nuage de points haute re'solution ; $b$ : mode 'le 3D basse re'solution; $\mathrm{c}:$ mode 'le 3D haute re'solution 
In 2013, similar stones were found in the adjacent grid square D8, but none of them contained engravings. The potential function of this intentional accumulation of rocks is unknown. Nevertheless, the piece under discussion is closely related to a domestic occupation. Thus, it cannot be described, or not exclusively, as a space of worship. Other remains potentially related to the artistic sphere include a slate plate with traces of red colour, some functional surface striations and two flat slate pebbles with engraved lines. None of them are spatially related to the engraved block. They were recovered at the eastern side of the site in relation to the most recent occupation layer.

\section{Description and analysis of the artwork}

Digital recording method

To produce a reliable and metrically accurate reproduction of this artwork, a combination of 2D and 3D digital recording techniques were used, following previous work (Domingo et al., 2013). For the 3D reconstruction, the remote sensing recording technique selected was close-range photogrammetry due to its flexibility in reconstructing $3 \mathrm{D}$ objects from different scales, the high accuracy of the results and the production of fast deliverables and low-cost solutions. After the photogrammetric performance, the following deliverables were obtained: high-resolution point clouds of the carved stone (Fig. 3a) from which subsequent 3D and 2D products were generated; a low-resolution 3D model of the whole stone (Fig. 3b); a high-resolution 3D model of the area with engravings (standalone) (Fig. 3c); contour lines: ortho-image mosaics of the artwork at different spatial resolutions, 10 microns $(0.010 \mathrm{~mm})$ for the close up areas with engravings and $0.100 \mathrm{~mm}$ for the rest (Fig. 4b); cross-sections; and a photorealistic 3D model with digital tracings superimposed (Fig. 8). A Canon 1Ds Mark III with two lenses, $24 \mathrm{~mm}$ and $50 \mathrm{~mm}$, was used for data acquisition. The first lens was used to deliver the general (low-resolution) data on the overall stone and the latter for high- resolution deliverables. No additional device was used for the acquisition except for a calibrated ruler, a color chart and targets surrounding the stone. The $2 \mathrm{D}$ and $3 \mathrm{D}$ recording deliverables follow an adaptation of the photogrammetric workflow presented in previous publications (Lerma et al., 2014). 


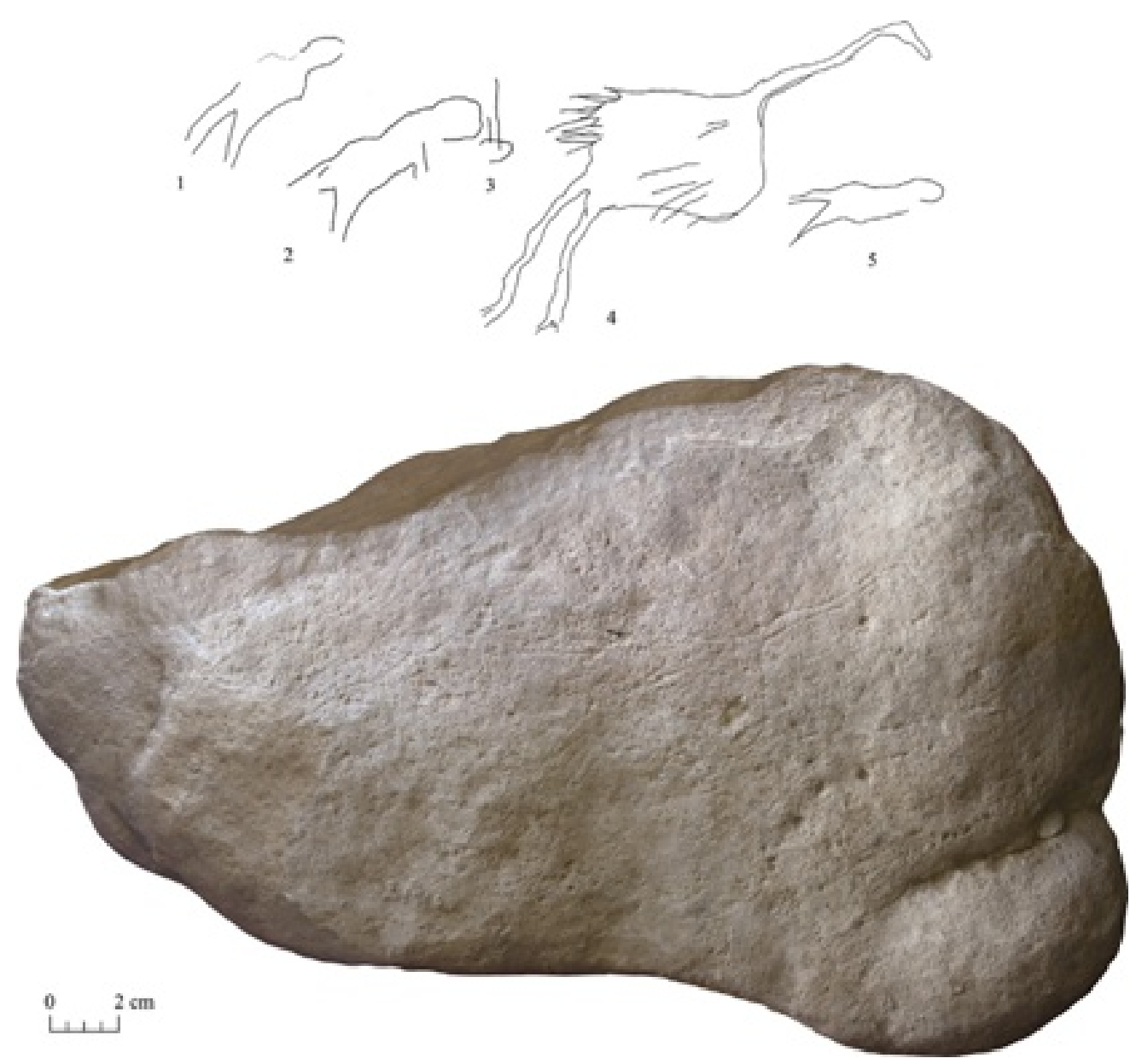

Fig. 4. Digital recording of the engraved bloque. Digital 2D drawing of the motifs and ortho-image mosaic. Enregistrement nume' rique du bloque grave'. Dessin nume'rique 2D des motifs et de la mosai"que d'orthoimages.

\section{Description of the piece}

The piece under study includes several figurative motifs finely engraved on a limestone rock of irregular shape and rounded edges. The rock measures $30.9 \times 20.7 \mathrm{~cm}$ in maximum dimension, and $17 \mathrm{~cm}$ of thickness (Fig. 4). The round edges are all natural, suggesting a fluvial origin for the rock. These features fit well with the location of the site, on a fluvial terrace containing similar limestone rocks. This suggests that local raw material was sourced to make the artwork.

The rock has triangular shape in cross-section and three main surfaces, with only one bearing engravings and the other two being un-retouched. There is no evidence of the intentional pre- treatment or fragmentation of the rock prior to engraving. While the engraved motifs are visible to the naked eye, the use of oblique light significantly improves viewing. Four of the five motifs are facing right, in a well-ordered linear composition using the entire space of the decorated surface. The motifs are evenly spaced, avoiding overlaps and resulting in a neat composition. This contrasts with other examples of similar age, in which overlapping motifs and 
strokes hinder interpretations. Engraving is the only technique used on this piece. Single and sporadically repeated strokes were used to reproduce the silhouettes of the motifs in profile, while ignoring the secondary anatomy (such as eyes, etc.). The incised strokes are mostly flowing and continuous, although several intersections are visible in the outline (especially in Fig. 4). This technical homogeneity, together with the clean and well-organized structure of the composition, suggests a unique phase of artistic activity.

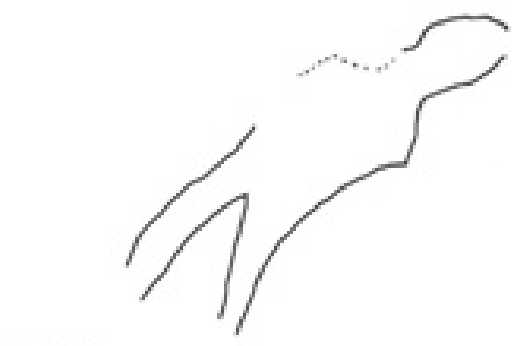

Motif 1

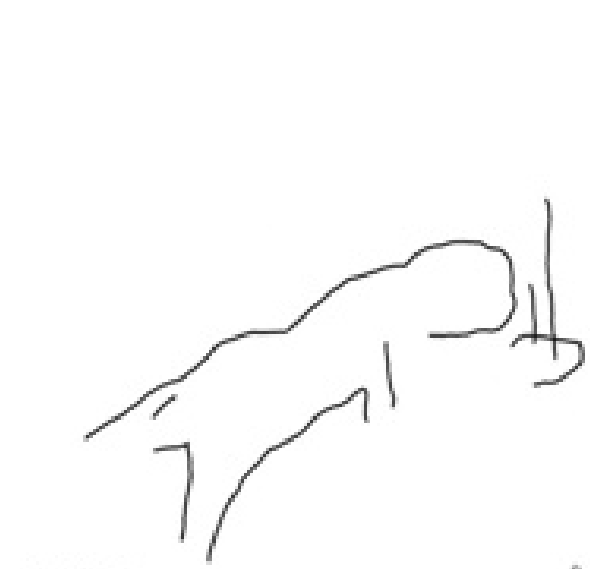

Motifs 2 - 3
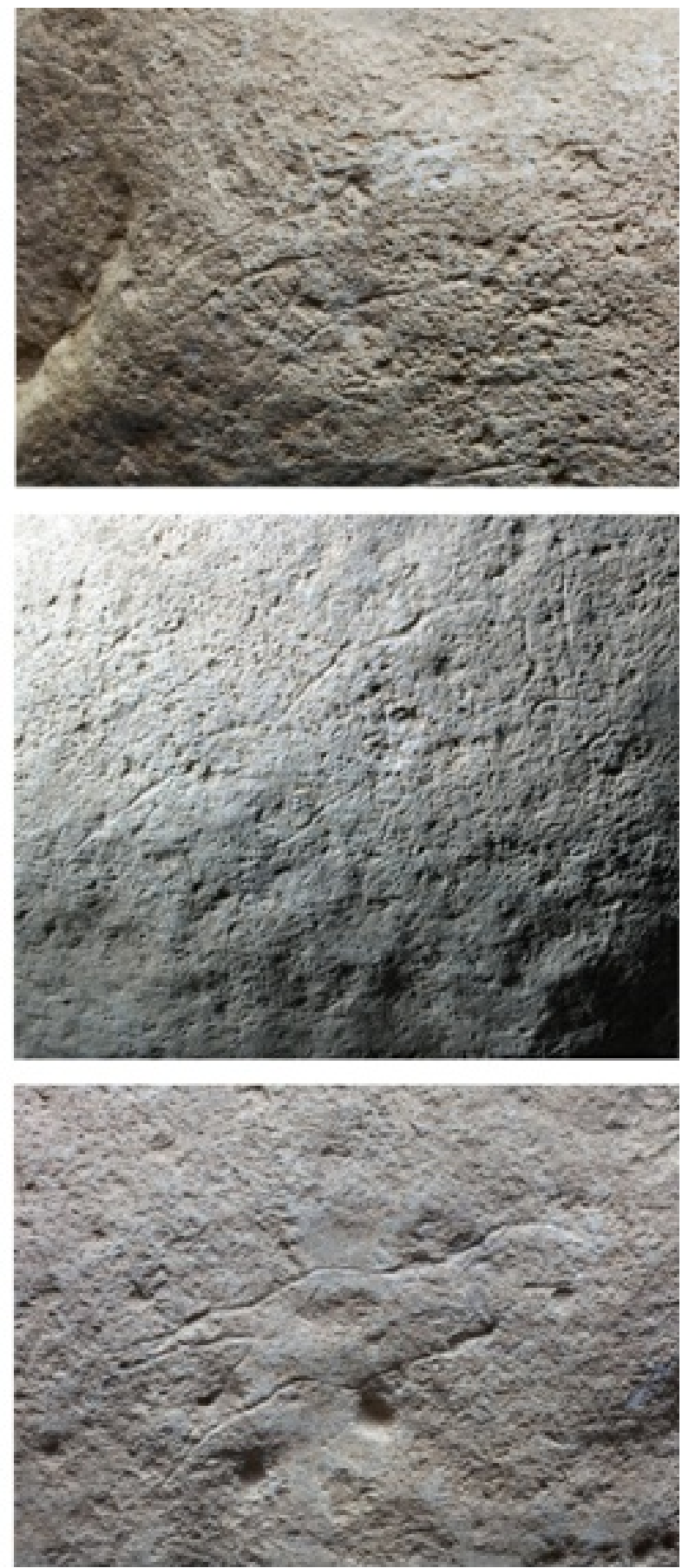

Fig. 5. Digital drawings to scale and close up photographs of motifs $1,2,3$ and 5 to scale.

Dessins nume'riques a' l'e'chelle et photographies de de'tail des motifs 1, 2, 3 et 5 a' l'e'chelle. 

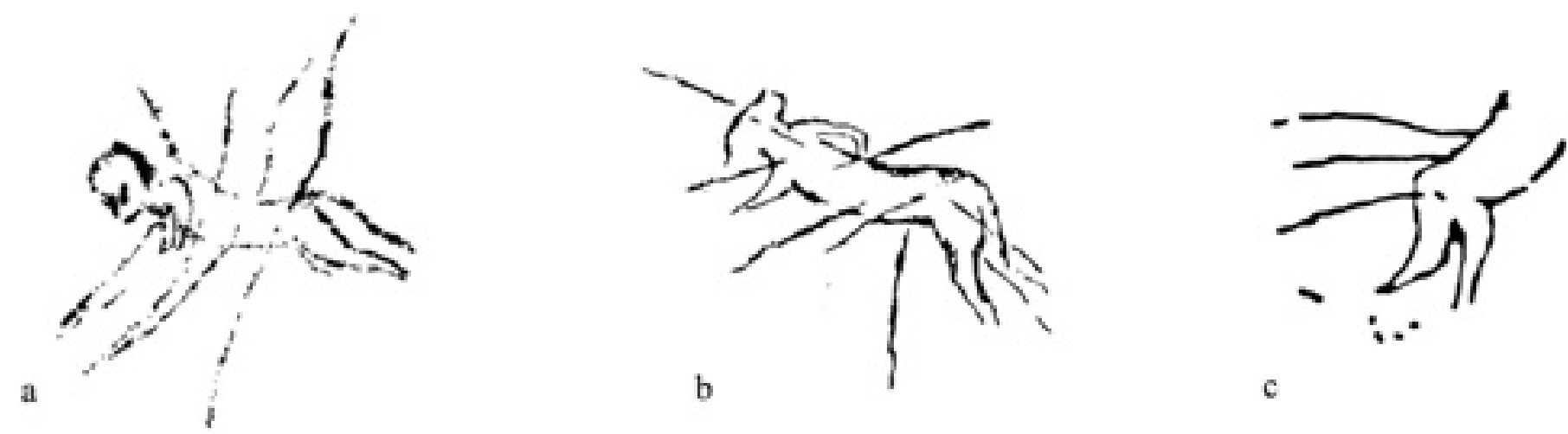

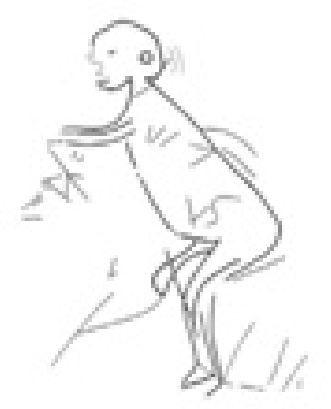

d

Fig. 6. Representations of humans in Palaeolithic art: a: Pech-Merle (Lorblanchet, 1984); b: Cougnac (according to Lorblanchet in Duhard, 1996); c: Cougnac (Duhard, 1996); d: Saint-Cirq (Delluc and Delluc, 1982); e-f: Combarelles (Archambeau and Archambeau, 1991); g: Mol1' del Salt (Garc1'a-Diez, 2004).

Figurations humaines dans l'art pale'olithique : a : Pech-Merle (Lorblanchet, 1984) ; b : Cougnac (d'apre`s Lorblanchet in Duhard, 1996) ; c : Cougnac (Duhard, 1996) ; d : Saint-Cirq (Delluc et Delluc, 1982) ; e-f : Combarelles (Archambeau and Archambeau, 1991) ; g : Molı' del Salt (Garc1'a-Diez, 2004).

The inventory of motifs includes:

- motif 1 (Fig. 5). Unidentified biped motif in right profile. The motif is leaning forward to the right towards the other motifs in the panel. This simplified representation only reproduces an outline, which is slightly eroded at the top left. An oval shape represents the head with no facial details. It is well differentiated from the body through the insinuation of the neck. From there, the contour lines, almost lost on the left side, widen again to indicate the start of the upper limbs, only partially depicted adopting a triangular shape. Such a shape could be interpreted as either a simplified human limb (as in the wounded humans of Pech-Merle or Cougnac) (Fig. 6) or a wing. Parallel lines sketch the lower limbs opened in an inverted "v". The feet or any flexing of the limbs are not depicted. Bipedalism is one of the distinctive features of anthropomorphic figures in Palaeolithic art, though it is not unique to humans but shared with birds. Thus, to interpret this motif as either an anthropomorphic figure or a chick it is necessary to closely analyse the graphic context;

- motif 2 (Fig. 5). Unsexed anthropomorphic figure leaning to the right. Globular head in right profile with a slightly suggestion of nasal and chin prominences. Both characteristics are considered as diagnostic signs of humanity (Duhard, 1996). The modelling dorso-lumbar line suggests the spinal curvature distinctive of 
humans when viewed from the side, while the neck (cervical) and the low back (lumbar) regions show the characteristic concave curve. Only one arm has been partially sketched. It is extended forward in the typical posture of other Palaeolithic anthropomorphs. Opened parallel lines, with no flexing of the limbs or representation of feet, seem to represent open scissors legs. No hands or internal details have been depicted. The analogue stance to other simplified and incomplete Palaeolithic anthropomorphs (such as the wounded humans from Cougnac or the anthropomorphs of Saint-Cirq or Combarelles) (Fig. 6) support interpretation of this motif as a simplified human;

- motif 3 (Fig. 5). Unidentified motif. Open oval with similar shape and size to the head of motifs 1 and

5. It is partially traversed by two uneven parallel lines. It could be either a discarded sketch of a figure, a sign or even a weapon related to anthropomorphic motif 2;

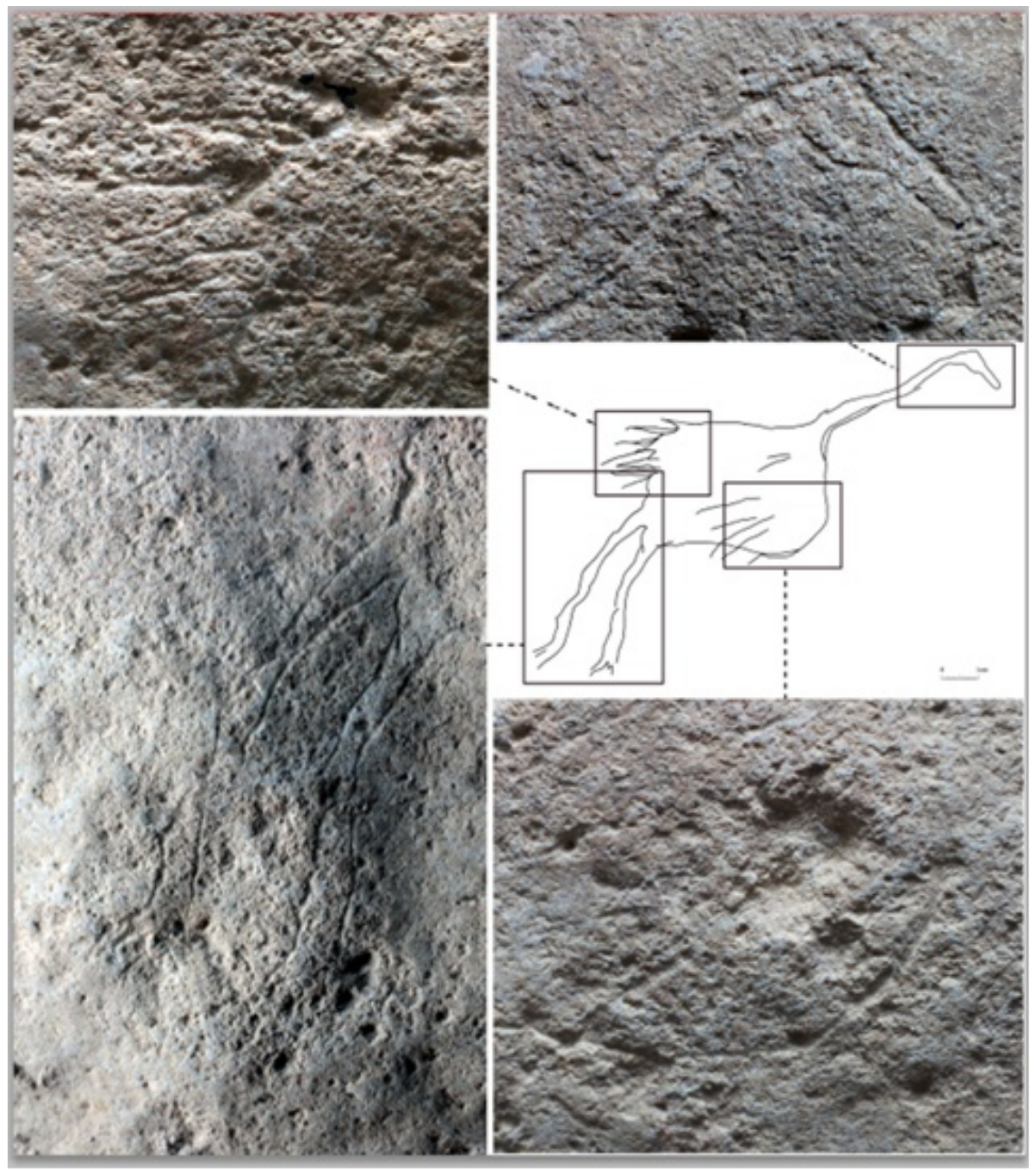

Fig. 7. Digital drawing to scale and close up photographs of motif 4.

Dessins nume'riques a' l'e'chelle et photographies de de'tail du motif no 4. 
- motif 4 (Fig. 7). Naturalistic and complete representation of a large bird facing right. The head, with a projecting mandible representing a beak, is disproportionately small compared to the body. This motif lacks internal details such as an eye, or any sort of plumage that might signify eyebrows or whiskers. The elongated thin neck shows a slightly S-shaped curve. This particular shape has been previously observed in other representations of birds and has been interpreted as depicting a dead animal (Jimenez et al., 2011). However, this shape is in fact characteristic of some species when viewed from the side. The legs adopt a nonnaturalistic, almost rigid, position. While most birds stand and walk with the thighs nearly horizontal, they generally swing the legs from the knees while their anterior toes are directed forward. But in this specimen both legs are nearly parallel, even from the knees, and the toes are directed downwards on the front leg and backwards on the back leg. This unrealistic posture may be due to the limited realism of the drawing, a deliberate aim to depict a dead animal or it may be distorted for an unknown reason. The massive rounded body includes anatomical details such as the tail feathers, as well as several slightly curved internal lines that appear to represent plumage. In contrast, the wings have not been explicitly depicted. The legs are slightly more naturalistic than in the surrounding figures, since they are complete. They include a slight bend of the ankle joint and an unrealistic representation of the toes. From a technical point of view, the dorso-lumbar line is continuous and has been produced with a single stroke, while the neck and the breast and belly line show the juxtaposition of several strokes, correcting the path at various points (the anterior part of the neck, the neck and chest joint, the belly and the belly and legs joint). In the area corresponding to the breast, an intentional hollow produced by impact could be suggesting that the animal had been hunted (whether for culinary motives, the feathers or other symbolic purposes), and not just being observed or revered. A comparison of the anatomical features of this figure with biological criteria along with finds from other Palaeolithic sites (Cremades et al., 1997; Jimenez et al., 2011), discussed below, suggests that this bird belongs to the family of cranes;

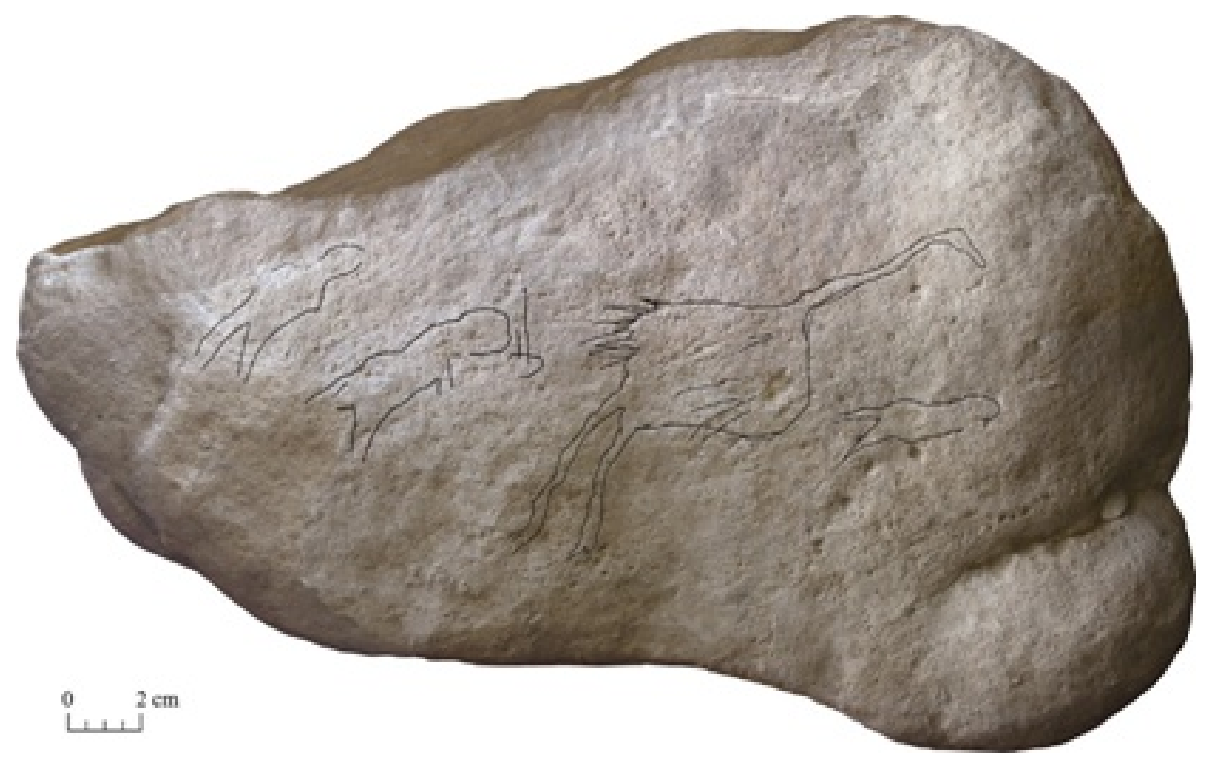

Fig. 8. Combination of 2D and 3D reproductions for portable art recording. Photorealistic 3D model with 2D digital drawings overimpossed.

Combinaison de reproductions 2D et 3D pour l'enregistrement de bloc grave'. Mode'le 3D re'aliste avec dessins nume'riques 2D surimpose's. 
- motif 5 (Fig. 5). Unidentified biped motif. Repeating the posture of other motifs this figure is also leaning to the right, although this time almost reaching the horizontal. The shapes of the head and lower limbs are similar to those of figure one, but with no evidence of upper limbs. The lower limbs also are depicted in an open scissors posture. As with figure one, the interpretation of this motif as either a human or a chick is complex and has to take into account the graphic context. While the general shape is quite similar to Fig. 1, the lack of arms, the excessive forward leaning and, particularly, the location of this beneath the bird 4 suggests that this motif is a young bird rather than a human.

Thorough analysis of the composition sheds some light on the art-making process (Fig. 8). Placement of the larger and most naturalistic figure of the assemblage, Fig. 4, the bird in the central space suggests that this was the focal point of the artistic creation. The remaining figures are smaller in comparison to this central figure. The difference in size could be interpreted as a way of emphasising the central bird or of indicating relative size differences among the motifs or as due to the reduced space available after depicting the central motif. The prominence of the central figure is increased through reduction in the naturalism of the other figures.

Figs. 1, 2, 4 and 5 are regularly spaced and aligned in an intentional linear composition facing the same direction, which creates a visual conection among them. Intentional linear arrangements, unconstrained by the morphology of the media, have been previously recorded in Palaeolithic art (Leroi-Gourhan, 1984; Macintosh, 1977). In addition, this linear composition has a narrative component as it creates a scene, discussed below. The body and limbs of motifs 1 and 2, in conjunction with the irregularities of the rock surface, draw an imaginary floor line leading towards the central bird. Though following the same direction, Figs. 4 and 5 draw a more horizontal trajectory that creates a sense of paired figures. Furthermore, Fig. 5 is not exactly located on the same level, but slightly upwards immediately under bird 4. This close connection between an adult and a potential offspring is not unique in Palaeolithic art (see previous examples in Fig. 9). What is unique to this piece from Hort de la Boquera is the presence of humans in a scenic connection that contains this sort of maternal scene.

Interpretation of the overall piece: birds, humans and a scenic composition

The interpretation of this piece calls first for a bird identification. This interpretation is crucial to interpreting the remaining figures as well as the scene as a whole, which takes into account the behavioural patterns of the species. Animal identification in ancient forms of art is not straightforward (see for example Macintosh's unsuccessful interpretation of most of the animals depicted at the Indigenous site of Doria Gudaluk, Northern Territory, Australia in 1977) (Macintosh, 1977). Nevertheless, the physical accuracy used to depict most mammals in European Palaeolithic art leads to the expectation that other less represented taxa also will be accurately reproduced. Analysis of the anatomical features (small head, elongated neck, globular body and long legs) together with previous taxonomic designations of Palaeolithic depictions of birds is key to our bird identification.

Previous studies have demonstrated that birds are depicted more often in portable art than in rock art (Cremades et al., 1997). Aquatic species, including Anatidae and waders, dominate (35\%); followed by birds of prey $(9,5 \%)$, passerine birds $(6 \%)$, including corvidae; and galliformes $(1 \%)$. Unfortunately, nearly $48 \%$ of 
the birds are taxonomically unidentifiable (Nicolau-Guillaumet, 2008). It is our understanding that Gruiformes (which are non-strictly acquatic but highly terrestrial birds) were probably counted as waders in this scheme. Our proposal is to include the bird under study within the group known as Gruiformes.

Palaeolithic depictions previously included in this order have been classified as either bustards (Otididae family) or cranes (Gruidae family). While bustards have large heads, pointed beaks and shorter and thicker necks and legs, cranes have smaller heads, more elongated beaks and thinner and longer necks and legs. Long, narrow and snake-like necks have also been identified among the anatidae, and more specifically among swans (such as those from the Gourdan and Teyjat sites) (Cremades et al., 1997). Considering in relation to these parameters the taxonomy of bird 4 should be restricted to these families: Otididae and Gruidae.

The beak of otididae, and specifically of bustards, is relatively shorter than their head. The neck, while long, is substantially shorter than the body and is particularly thick at the base, where the ruff or collar is located. This species has long and robust legs, since they are highly terrestrial. Their feet have three forward-facing toes. The male bustards have long neck bristels, and they expand their chin and tail feathers to attract females (Alonso and Palaci'n, 2009).

Cranes have a more graceful complexion, with a more balanced proportion between head and beak. Their neck and legs are more extended in relation to their body when compared to Otididae. Their neck can adopt a snakelike sinuosity, as in the image at Hort de la Boquera.

Reference to these biological criteria suggests that bird 4 should be interpreted as a crane. The Palaeolithic artistic assemblage includes other representations of cranes, such as the bird of Arancou, La Vache, Gargas, Cauna de Belvis and one of the birds from Laugerie-Basse [6], two complete birds from Labastide (HautesPyre'ne' es) (D'Errico, 1994; Simonnet, 1947) and the bird from Bruniquel (Tarn-et-Garonne) (Capitan et al., 1909) (Fig. 10). The bird of Gargas also has been interpreted as a potential Great Auk, though D'Errico (1994) does not support this view. 
a

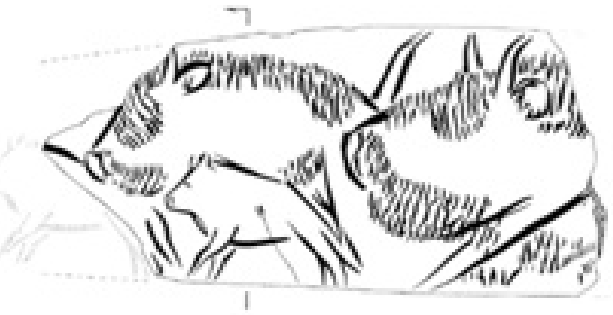

b
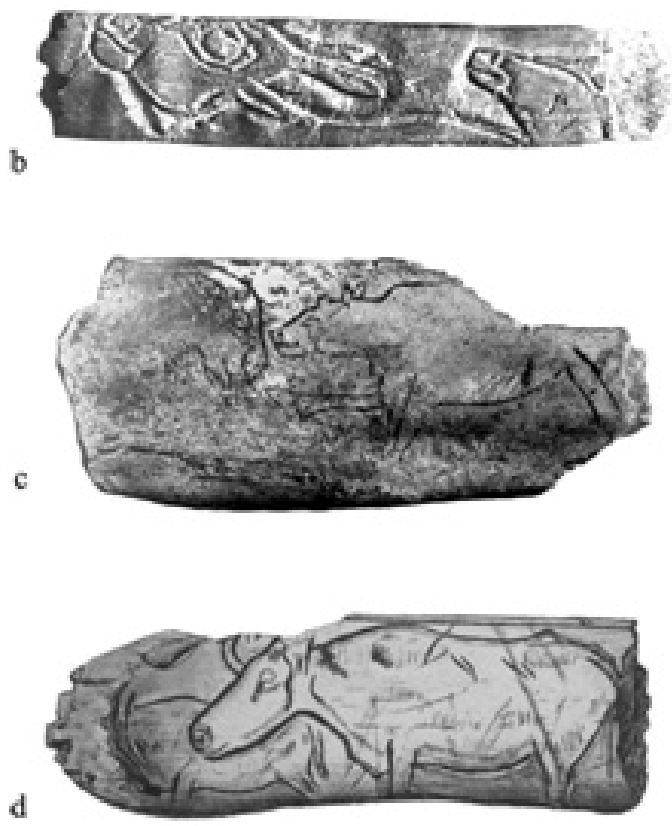

d

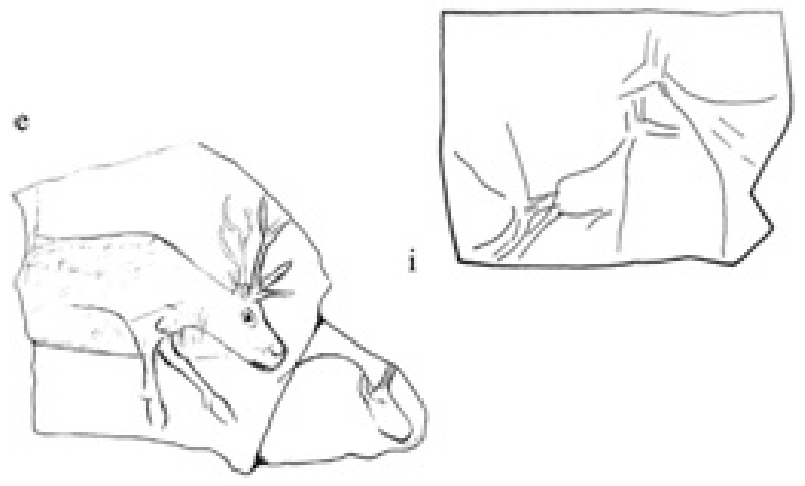

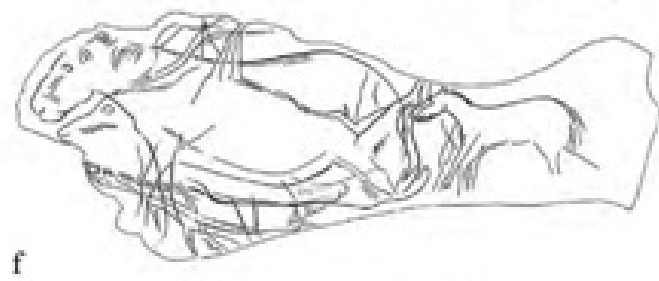

f

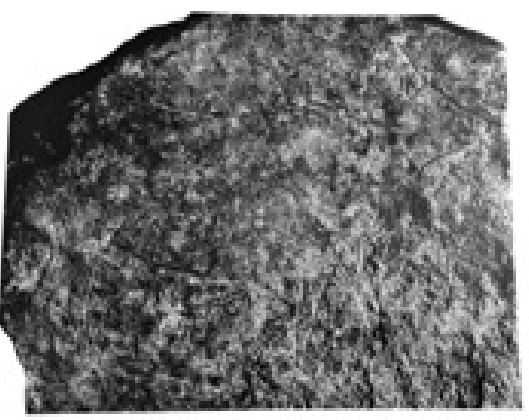

h
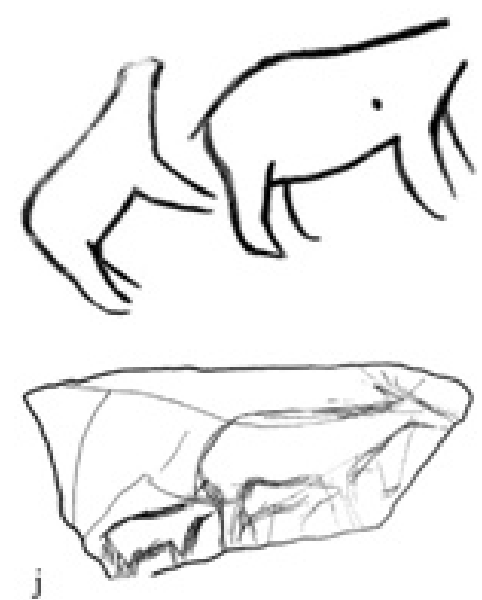

k

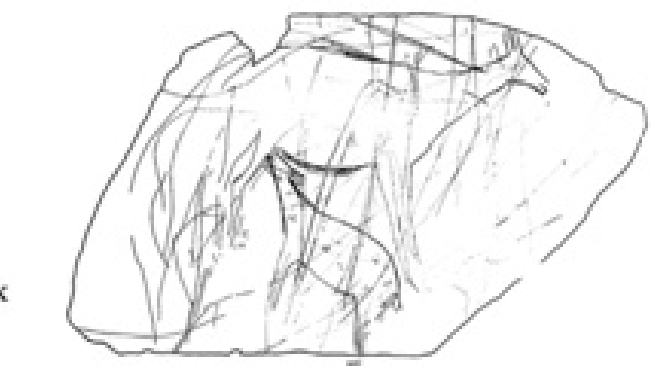

Fig. 9. Palaeolithic scenes including adult animals and their offspring: a: bisons and calf from abri Morin (Deffarge et al., 1975); b: two deer from Lauregie-Basse (Chollot, 1964); c: bison and her calf from Brassemmpouy (Chollot, 1964); d: cow and calf from Mas d'Azil (Piette, 1907); e: reindeer licking her fawn from Abri Lachaud (Cheynier, 1965); f: horse and foal from Mas d'Azil (Delporte and Mons, 1975); g: female reindeer and her offspring from La Madeleine (Sieveking, 1979); h: headless bear and potential young from Ekain (Barandiara' $\mathrm{n}$ and Altuna, 1969); i-k: deers and fawns in different attitudes from Cova del Parpallo' (Villaverde, 1994a). 
Sce'nes du Pale'olithique montrant des animaux adultes et juve'niles : a : bisons et veaux, abri Morin (Deffarge et al., 1975) ; b : deux cerfs, Lauregie-Basse (Chollot, 1964) ; c : bison et son veau, Brassemmpouy (Chollot, 1964) ; d : Vache et veau, Mas d'Azil (Piette, 1907) ; e : renne le'chant son faon, Abri Lachaud (Cheynier, 1965) ; f : cheval and poulain, Mas d'Azil (Delporte and Mons, 1975) ; g : renne femelle et son petit, La Madeleine (Sieveking, 1979) ; h : ours sans te`te et probable jeunes, Ekain (Barandiara'n and Altuna, 1969) ; i-k : cerfs et faons dans diffe' rentes attitudes, Cova del Parpallo' (Villaverde, 1994a).

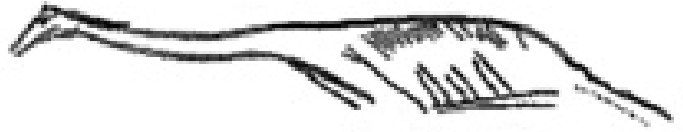

a

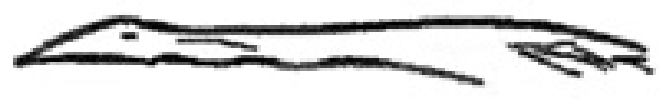

b

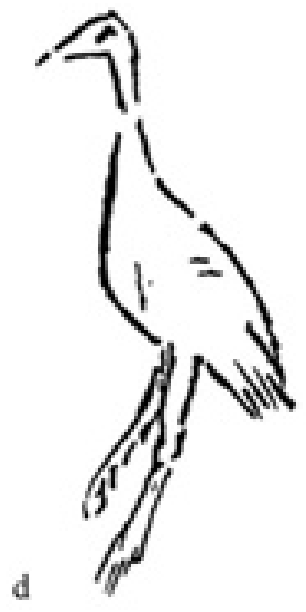

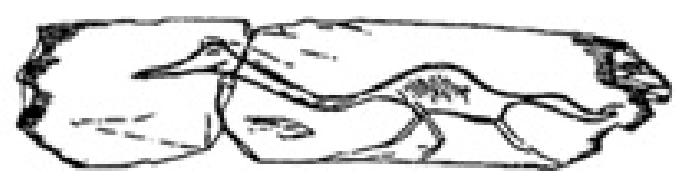

c
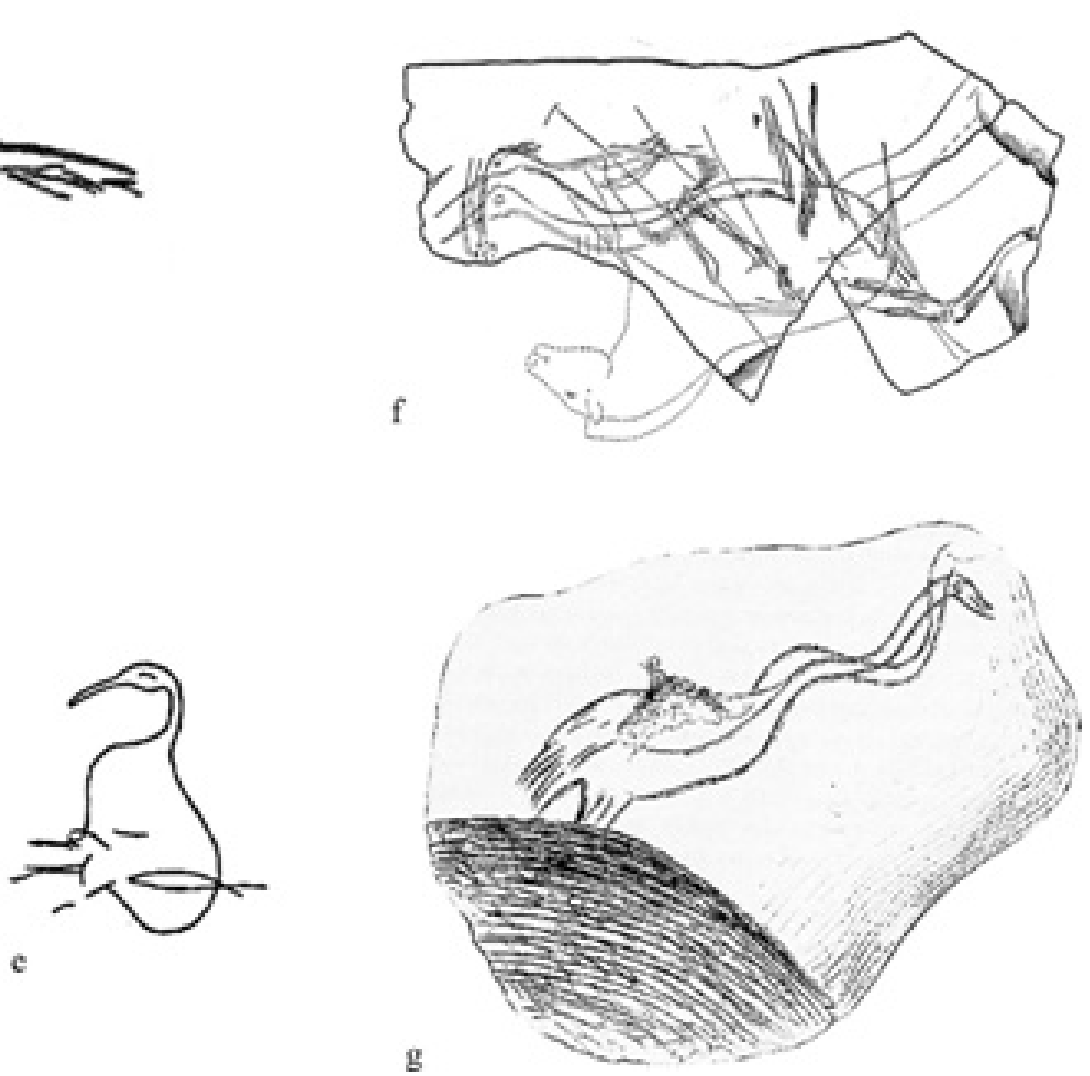

Fig. 10. Palaeolithic representations of cranes: a: Arancou (Cremades et al., 1997); b: La Vache [Buisson in (Cremades et al., 1997)]; c: Cauna de Belvis (Sacchi in Cremades et al., 1997); d: Laugerie-Basse (Paumier in Cleyet-Merle and Madelaine, 1995); e: Gargas (Barrie` re in Cremades et al., 1997); f: Labastide (Simonnet, 1947); g: Bruniquel (Capitan et al., 1909).

Repre'sentations pale'olithiques de grues : a : Arancou (Cremades et al., 1997) ; b : La Vache [Buisson in (Cremades et al., 1997)] ; c : Cauna de Belvis (Sacchi in Cremades et al., 1997) ; d : Laugerie-Basse (Paumier in Cleyet-Merle and Madelaine, 1995) ; e : Gargas (Barrie're in Cremades et al., 1997) ; f : Labastide (Simonnet, 1947) ; g : Bruniquel (Capitan et al., 1909). 
Nowadays the European Gruidae family includes the common crane (Grus grus) and the demoiselle crane (Grus virgo) (Peterson et al., 1967). However, the Pleistocene fossil record also includes Grus primigenia, Grus bogatshevi and Grus melitensis (Arribas, 2004). Seasonal movement is typical of these species, especially in migratory cranes. This genus almost invariably lays two eggs, and exceptionally three, an observation that is relevant to interpretation of the scene discussed in this paper. Young cranes remain with their parents throughout the non-breeding period (Meine and Archibald, 1996). Thus, both migratory patterns and the presence of the juvenile are indicators of seasonality.

Interpretation of the figures surrounding bird 4 is far more complex. Are they humans, young chicks or a mixture of both? The distinction between humans and animals often is ambiguous in Palaeolithic art, as it is in this piece. Bipedalism is a key to identifying humans in a graphic repertoire dominated by quadrupeds. However, distinguishing between birds and humans is not straightfor- ward, since both are bipedal. Therefore, other details are needed for identification. In the art object under discussion, except for bird 4, the figures are unrealistic and simplified. For some researchers interpretation of motifs 1,2 and 5 as chicks would fit well with our current understanding of Palaeolithic scenic compositions, as there are several maternal scenes known so far (Fig. 8).

Furthermore, this interpretation is consistent with the reproductive patterns of cranes, as cranes usually lay two eggs (and exceptionally three or even four), with a survival rate of one or two young chicks (and exceptionally three). Within this scenario, the representation of a maternal scene of a mother crane surrounded by three young chicks would sound reasonable.

However, two of the figures in this scene include traits that previously have been identified as signs of humanity. These are the presence of a globular head with some facial traits (motif 2), over a thin neck (motifs 1 and specially 2), the indication of arms (motifs 1 and 2) and the upright position (motifs 1 and 2). In our view, the humanity of Fig. 2 is indisputable, considering the characteristics discussed above. The interpretation of motifs 1 and 5 is less secure. However, the scenic coordination between motifs 1 and 2 and motifs 4 and 5 supports an interpretation of the former as potential humans and the later as potential birds. Without the presence of motif 2, motifs 1 and 5 could be interpreted as chicks, on the basis of their formal similarities, except for the excessive forward bending and the lack of arms of the later. Furthermore, the triangular shape of the arm of motif 2 could be interpreted as matching the shape of a wing, and the lack of beak, also absent in motif 5, could be argued to be due to a simplification of juveniles in Palaeolithic art. According to Lorblanchet ambiguity in Palaeolithic human representations, rather than the artists' inability to reproduce the human body, could be related to what he identifies as a voluntary denial of the human shape (Lorblanchet, 1989), which he argues is used by Palaeolithic artists to reflect the close liaison between humans and animals. This connection between humans and birds has been previously identified in some bird-headed humans discovered at Altamira and Lascaux (Lorblanchet, 1989: 122). In both cases, these human figures include a pronounced lengthening of the face that Lorblanchet interprets as deliberate (Lorblanchet, 1989: 124). Interestingly though, while in these examples the ambiguous images have beaks, in the scene under study none of the anthropomorphic figures have elongated faces. Thus, what moves us to interpret Fig. 5 as a chick, in contrast to motifs 1 and 2 as humans, is the lack of neck and arms, the position of the body nearly reaching the horizontal and particularly the analysis of the narrative context, that is, the location beneath bird 4. 
Thus, to us the identification of motifs 2 and 4 as a human and a crane respectively is unquestionable. Moreover, the ambiguity of motifs 1 and 5 forces us to deeply consider the graphic context and to discover a scene in which a crane and her chick are being observed, followed, hunted or mimicked by two humans. Such a scene is unique in Palaeolithic art, as discussed below.

\section{Discussion: placing the piece in the artistic context}

Evidence of Palaeolithic art in North-eastern Iberia is rare. All examples are located in southern Catalonia and belong to the final stages of the Upper Palaeolithic (Fullola et al., 2015; Garc1'a-Diez and Vaquero, 2015, 2006; Garc1'a-Diez, 2004). Rock art examples include a potentially Magdalenian engraved deer at la cova de la Taverna (Fullola and Viñas, 1985) and the already destroyed black silhouette of a rampant bull at Moleta de Cartagena site (Ripoll, 1965). The recently discovered engraved deer at Parellada IV (Serra de Llaveri'a, Tarragona), controversially ascribed to the Levantine rock art tradition (Vin as et al., 2010), fits better within Final Palaeolithic artistic conventions (Villaverde et al., 2012: 106-107).

The portable art assemblage is a little more extensive, although only two sites include figurative motifs so far, since the hypothetical ibex head from Tut de Fustanya' (Girona) has been already discarded (Villaverde, 1994b: 140; Garc1'a-Diez et al., 2002: 167). The figurative assemblage of Palaeolithic portable art includes the engraved plaques from Sant Gregori del Falset (Vilaseca, 1934; Fullola et al., 1990) and more recent finds at Molı' del Salt (Vimbodı', Tarragona) (Garci'a-Diez et al., 2002; Garc1'a-Diez and Vaquero, 2006, 2015). The latter date to between $12.500 \mathrm{~T} 100 \mathrm{BP}(15.129-14.230 \mathrm{cal}$. BP) and 10.840 T $50 \mathrm{BP}(12.801-12.682 \mathrm{cal}$. BP), with a former phase or phase A dated to the Late Upper Magdalenian (plaques 1 and 2), which is contemporary to the piece from Hort de la Boquera. The most recent phase is dated to the Epimagdalenian (plaques 3 and 4). Sant Gregori finds are ascribed to the Epimagdalenian (Garci'a-Argu" elles et al., 1992; Fullola et al., 2015). Interestingly, one of the pieces from Moli' del Salt that is contemporary to our find also includes a potential anthropomorphic figure (Garc1'a-Diez et al., 2002) (Fig. 6g). This is the only human parallel in the region even though it lacks formal similarities to those from l'Hort de la Boquera. The new find fits well within the so called Ancient Phase of the portable art assemblage in Northern Mediterranean Iberia (Garci'a-Diez and Vaquero, 2006), which is characterized by the local procurement of raw materials, incomplete anatomical formats (except for bird 4), the absence of secondary anatomy, scarce infilling and synthetised formal figurative conception. However, the new discovery introduces innovations in the region, such as:

- an almost complete and naturalistic figure (bird 4), in contrast to the synthetic and incomplete character of previous finds;

- the lack of non-figurative motifs which is quite common in previous examples (except for motif 3 which could be a sign, but also an incomplete figure or a weapon);

- the cleanliness and clarity of the composition, with no overlaps in the separate depictions, in contrast to previously known pieces;

- the narrative component of this new scene, absent in previous examples; and

- the first evidence of a bird. 
Taken together, these characteristics establish this piece into a singular find within the region. If we expand our view to the Palaeolithic assemblage as a whole, the scene from l'Hort de la Boquera maintains its singularity. Representations of humans (excluding female figurines) and birds are not unique in Palaeolithic art but they are infrequent when compared to other represented species (aurochs, horses, deer or ibex). Both types of figures have been recorded since the Aurignacian (the Lion man from Hohlenstein Stadel, the anthropomorph from Geissenklo" sterle; or the water bird figurine from Hohle Fels - Germany -, to name a few) (Lorblanchet, 1989; Conard, 2003). Nonetheless, their frequency increases significantly from the Magdalenian (Duhard, 1996; Cremades et al., 1997), reflecting a shift in the decisions made by prehistoric human groups. To some researchers this growth of human representations during the Magdalenian reveals an increasing anthropocentrism (Archambeau and Archambeau, 1991: 80), or a sign of awareness of the people's social role (Duhard, 1996: 14). An increase in the depictions of birds could be due to an upsurge in the exploitation of small game at the end of the Palaeolithic. However, as observed by Cremades et al. (1997: 214), migratory species are the birds that are most represented, which demonstrates that Palaeolithic artists did not necessarily depict the most common species, but also included rare species. Both would have had some sort of symbolism.

The uniqueness of the find at L'Hort de la Boquera also is apparent when considered in terms of composition. While anthropomorphs are occasionally integrated into scenic compositions, especially in portable art (the scenes of Bruniquel, Cha`teau des Eyzies, Laugerie-Basse, Mas d'Azil, Pe'chialet, Raymonden, Roc-de-Sers or La Vache) (Duhard, 1996), birds almost always are depicted in isolation or in relation to other animals [the bird-bison association at Altxerri or Altamira sites (Altuna and Apellaniz, 1976)] or the association of chicks, deer, seals and fish at La Vache cave (Cremades, 1997), and rarely with humans. As noted by Duhard, in the scenic relation between humans and animals there is a positive and a negative selection of species (Duhard, 1996: 178). Given their rarity in Palaeolithic art, birds are among the negative selections. This drew Duhard's attention since birds were certainly eaten in the past. Our discovery at Hort de la Boquera is one of the few exceptions to Duhard's observation.

Previous examples of scenes with humans and birds in Palaeolithic Europe include the Lascaux Shaft Scene (France) (Aujoulat, 2004: 158-161), which is the only one in rock art; and two examples in portable art: a perforated baton discovered at Abri Me'ge (Teyjat, Dordogne) (Capitan et al., 1909) and the Great Hunter plaque from Go" nnersdorf (Germany) (plaque 168A) (Bosinski, 2006) (Fig. 11). The perforated baton from Abri $\mathrm{Me}$ ' ge includes a complex composition of three swans and three potentially anthropomorphic figures, described as diablotins (little demons), sharing space with two horses, three snakes or eels and the head of a hind (Capitan et al., 1909; Duhard, 1996: 116-119). This composition, however, lacks the scenic or narrative component of the piece under study.

While motifs are endowed with a narrative component in the Lascaux shaft scene, none of the bird- like forms are literal representations of birds. One is a bird-headed human apparently being hunted by a bison, and the other is a bird carved at the end of a stick, reminiscent of the spear-thrower with a carved capercaillie from Mas d'Azil (Charrie're, 1968). Thus, while reflecting some symbolic meaning for birds in Palaeolithic art and certain connections between birds and humans, as in the scene under study, there is no narrative content as there is with the piece from l'Hort de la Boquera or Go" nnersdorf. Finally, the piece from Go" nnersdorf 
includes a composite animal (half reindeer-half horse) that seems to be rushing impetuously to the right and two birds (a water hen and a goose), which Bosinski (2006: 22) interprets as fleeing a partial representation of a hunter (a head with rounded eyes). Within this scenario, the birds would be the target or at least the point of attention of an anthropomorphic figure, which makes this piece the closest to the new find at l'Hort de la Boquera. In the piece from Go" nnersdorf, however, the incomplete human and the tangled nature of the scenic composition hinders any reading of a possible narration, contrary to the scene on the new object from l'Hort de la Boquera.

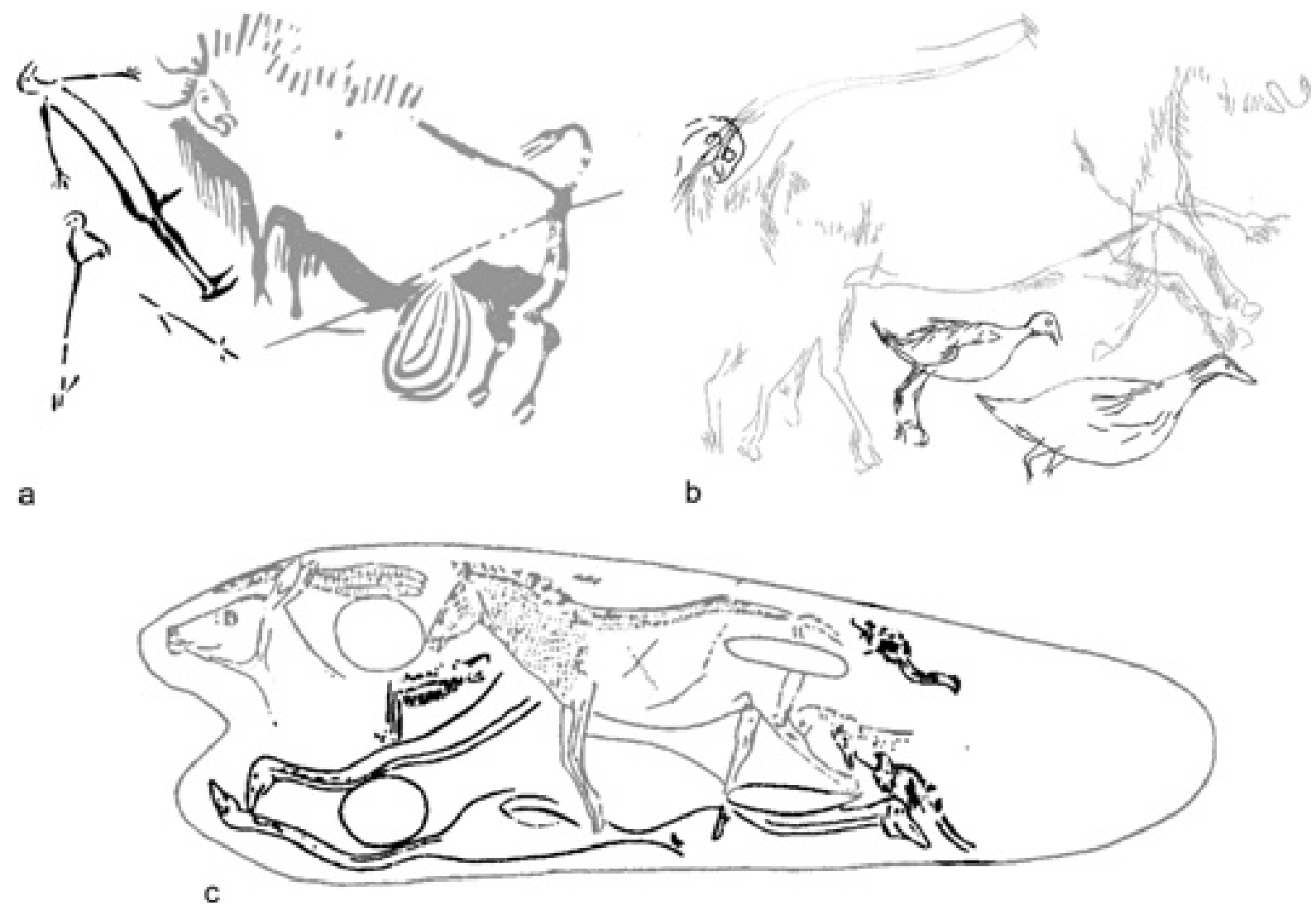

Fig. 11. Palaeolithic compositions and scenes including humans and birds: a: Lascaux shaft scene [according to Glory in (Duhard, 1996: 98)]; b: piece of portable art from Go" nnersdorf (Bosinski, 2006); c: perforated baton from Teyjat (according to Marshack in Duhard, 1996: 116).

Compositions et sce'nes du Pale'olithique comprenant des humains et des oiseaux : a : sce'ne du puits, Lascaux [d'apre`s Glory in (Duhard, $1996: 98$ )] ; b : bloc grave', Go“nnersdorf (Bosinski, 2006) ; c : ba`ton perce', Teyjat (d'apre`s Marshack in Duhard, 1996 : 116).

The new piece from l'Hort de la Boquera is an outstanding visual sample of human/bird interaction during the Late Upper Magdalenian in Europe. Its unique combination of qualities includes the singularity and naturalism of bird 4, the cleanliness and clarity of the scene, a clear narrative component, and a composition in which a possible maternal scene of birds coexists with one or two humans. Taken together, these graphic elements introduce a new aspect to European Palaeolithic art. 


\section{Conclusions}

The new sample of portable art recovered at l'Hort de la Boquera provides a singular visual sample of human/ bird interaction during the Late Upper Magdalenian both in Northeaster Iberia and in the European Palaeolithic.

This new find is exceptional in terms of the rarity of Palaeolithic art in the area and the infrequency of the motifs depicted (birds and humans) and themes (a scenic composition) in the region and in European Palaeolithic art. Moreover, this find is one of the few visual examples of human/bird interactions during the Palaeolithic. This new example not only includes a narrative scene, which is infrequent in Palaeolithic art, but also combines within the same scenic composition a potential maternal scene and a hunting scene, or at least a visual account in which birds are the target of human attention, or followed or imitated by one or two human figures. As such, this new find is unique in the European Palaeolithic repertoire.

Though the specific meaning of the scene cannot be determined, this new discovery reminds us that birds had both an economic and a symbolic role in European Palaeolithic societies.

\section{Acknowledgements}

The authors would like to thank several researchers for their contribution at different stages of this paper preparation. To E. Brieva for her significant contribution in the field. We also thank our colleagues V. Villaverde for his suggestions regarding the potential interpretation of the motifs, and G. Bosinski, J. Zilha o, F. D'Errico and M. Garci'a-Diez for providing references and/or publications of interest to this work. Finally, we thank C. Smith for her suggestions regarding content and English translation, and M. Teixido' for her comments on the French abstract.

The authors acknowledge the support of several funding programs and projects: Fieldwork funds granted to P. Garc1'a-Argu" elles and J. Nadal by Generalitat de Catalunya (CL T009/18/00001). Projects HAR2017-86509P granted to J.M. Fullola and P. Garc1'a-Argu" elles and HAR-2016-80693-P granted to I. Domingo by the Spanish Ministry of Economy, Industry and Competitiveness; and the Quality Research Group 2017SGR-11, granted to J.M. Fullola by Generalitat de Catalunya. 
References

Alonso, J.C., Palaci'n, C., 2009. Avutarda - Otis tarda. In: Salvador, A. (Ed.), Enciclopedia Virtual de los Vertebrados Españoles. Sociedad de amigos del MCN. Museo Nacional de Ciencias Naturales. CSIC, Madrid http://www.vertebradosibericos.org/ Altuna, J., Apellaniz, J.A., 1976. Las figuras rupestres paleolı'ticas de la cueva de Altxerri (Guipuzcua). Sociedad de Ciencias Aranzadi, San Sebastia' n.

Archambeau, C., Archambeau, M., 1991. Les figurations humaines parie' tales de la grotte des Combarelles. Gallia-Pre' histoire 33, 53-81.

Arribas, O., 2004. Fauna y paisaje de los Pirineos en la era glaciar. Lynx edicions, Barcelona. Aujoulat, N., 2004. Lascaux. Le Geste, l'Espace et le Temps. Seuil, Paris.

Barandiara' n, J.M., Altuna, J., 1969. La cueva de Ekain y sus figuras rupestres. Munibe 21, 331-385.

Bergada', M.M., 1998. Estudio geoarqueolo' gico de los asentamientos prehisto' ricos del Pleistoceno Superior y el Holoceno inicial en Catalunya. BAR International Series 742, Oxford.

Bosinski, G., 2006. Le Grand Chasseur. Re' flexion sur une sce' ne grave' e de Go“ nnersdorf (Rhe' nanie, Allemagne). In: Maillo, J.M., Baquedano, E. (Eds.), Miscela' nea en homenaje a Victoria Cabrera. Zona Arqueolo' gica 7 (II), 12-23.

Capitan, L., Breuil, H., Bourrinet, P., Peyrony, D., 1909. Observations sur un ba^ton de commandement orne' de figures animales et de personnages semi-humains. Revue mensuelle de l'E' cole d'Anthropologie de Paris $19,62-76$.

Charrie` re, G., 1968. La sce` ne du puits de Lascaux ou le the` me « de la mort simule' e ». Revue de l'histoire des religions 174 (1), $1-25$.

Cheynier, A., 1965. L'abri Lachaud a' Terrasson. Pre' histoire, 16. Presses Universitaires de France, Paris.

Chollot, M., 1964. Collection Piette, Art Mobilier pre' historique. Muse' e des Antiquite's Nationales.

$\mathrm{E}^{\prime}$ ditions des Muse' es Nationaux, Paris.

Cleyet-Merle, J.J., Madelaine, S., 1995. A' propos d'une repre' sentation d'e' chassier de LaugerieBasse (Les Eyzies de Tayac, Dordogne). Paleo 7, 255-258.

Conard, N.J., 2003. Palaeolithic ivory sculptures from southwestern Germany and the origins of figurative art. Nature 426, 830- 832 .

Cremades, M., 1997. Bestiaire, environnement animal, saisonnalite' a’ la grotte de la Vache (Alliat, Arie' ge). Bulletin de la Socie' te' Pre' historique Franc, aise 94 (4), 455-470.

Cremades, M., Pellicer, M., Sanchidria' n, J.L., 1997. Nouvelles figurations d'oiseaux de l'art mobilier pale' olithique franco- espagnol. Pale' o 9, 371-387.

Deffarge, R., Laurent, P., Sonneville-Bordes, D., 1975. Art mobilier du Magdale' nien supe' rieur de l'Abri Morin, a` Pessac-sur- Dordogne (Gironde). Gallia-Pre' histoire 18, 1-64.

Delluc, B., Delluc, G., 1982. Les trois figures humaines de la grotte de Saint-Cirq (Dordogne). Ars Praehistorica 1, 147-150. Delporte, H., Mons, L., 1975. Omoplate de' core' e du Mas d'Azil (Arie' ge). Antiquite' s Nationales 7, 14-23.

D’Errico, F., 1994. Birds of Cosquer Cave. The Great Auk (Pinguinus impennis) and its significance during the Upper Palaeolithic. Rock Art Research 11 (1), 45-57.

Domingo, I., Villaverde, V., Lo' pez, E., Lerma, J.L., Cabrelles, M., 2013. Latest developments in rock art recording: towards an integral documentation of Levantine rock art sites combining $2 \mathrm{D}$ and $3 \mathrm{D}$ recording techniques. Journal of Archaeological Science 40, 1879-1889. 
Duhard, J.P., 1996. Re' alisme de l'image masculine pale' olithique. Je' ro^me Millon, Grenoble.

Fullola, J.M., 1978. L'Hort de la Boquera. Un nou jaciment a la Vall del Montsant. Butllet1' de la Societat Arqueolo` gica Tarraconense, e' poca V (141-44), 3-15.

Fullola, J.M., Domingo, I., Roma' n, D., Garc1'a-Argu“ elles, P., Garc1'a-Diez, M., Nadal, J., 2015. Small seeds for big debates: past and present contributions to Paleoart studies from North-eastern Iberia. In: Bueno, P., Bahn, P. (Eds.), Prehistoric Art as Prehistoric Culture. Archeopress archaeology, Oxford, pp. 157-169.

Fullola, J.M., Mangado, X., Tejero, J.M., Petit, M.A., Bergada' , M.M., Nadal, J., Garc1'a-Argu“ elles, P., Bartrol', R., Mercadal, O., 2012. The Magdalenian in Catalonia (northeast Iberia). Quaternary International 272-273, 55-77.

Fullola, J.M., Viñas, R., Garcı'a-Argu“ elles, P., 1990. La nouvelle plaquette grave' e de Sant Gregori (Catalogne, Espagne). In: L'art des objets au Pale' olithique, volume 1 : L'art mobilier et son contexte. Direction du Patrimoine, Paris.

Fullola, J.M., Viñas, R., 1985. El primer grabado naturalista en cueva de Cataluña: la cova de la Taverna (Margalef de Montsantm Priorat, Tarragona). Caesaraugusta 61-62, 67-78.

Garc1'a-Argu“ elles, P., 1983. El poblament prehisto` ric de la vall del Montsant a partir dels tallers de superfi 'cie. Universitas Tarraconensis VI, 129-140.

Garc1'a-Argu“ elles, P., Nadal, J., Fullola, J.M., Bergada`, M.M., Domingo, I., Allue`, E., et al., 2014. Nuevas interpretaciones del Paleolı'tico Superior final de la Cataluña meridional: el yacimiento de l'Hort de la Boquera (Priorat, Tarragona). Trabajos de Prehistoria 71 (2), 242-260.

Garc1'a-Argu” elles, P., Adserias, M., Bartrolı', R., Bergada' , M.M., Cebria' , A., Doce, R., et al., 1992. S1 'ntesis de los primeros resultados del programa sobre Epipaleolítico de la Cataluña central y meridional. In: Arago' n/Litoral mediterra' neo. Intercambios culturales durante la Prehistoria. Institucio' n Fernando el Cato' lico, Zaragoza269-284.

Garc1'a-Diez, M., 2004. El grafisme moble del Molı' del Salt i la figuracio' moble durant el Tardiglaciar en el vessant mediterrani de la Penı'nsula Ibe' rica. In: Vaquero, M. (Ed.), Els darrers cac, adors-recol lectors de la Conca de Barbera' : el jaciment de Molı' del Salt (Vimdobi'). Excavacions 1999-2003. Museu-arxiu Montblanc i Comarca, Montblanc, pp. 211-263.

Garc1'a-Diez, M., Vaquero, M., 2015. Looking at the camp: Paleolithic depiction of a hunter-gatherer campsite. PLoS One 10 (12), e0143002.

Garc1'a-Diez, M., Vaquero, M., 2006. La variabilite' graphique du Molı' del Salt (Vimbodi', Catalogne, Espagne) et l'art mobilier de la fin du Pale' olithique supe' rieur a' l'est de la Pe' ninsule Ibe' rique. L'Anthropologie 110 (2006), 453-481.

Garcı'a-Diez, M., Martı'n, J., Gene' , J.M., Vaquero, M., 2002. La plaqueta gravada del Molı' del Salt (Vimbodı', Conca de Barbera') i el grafisme Paleolı'tic/Epipaleolı'tic a Catalunya. Cypsela 14, 159-173.

Jimenez, J., Sa' nchez, A., Garc1'a, M., 2011. Nuevo examen de los grabados paleolíticos de El Pendo (Cantabria, España).

Consideraciones sobre las aves del arte paleolı'tico de la Penı'nsula Ibe' rica. Trabajos de Prehistoria 68 (1), $147-158$.

Lerma, J.L., Navarro, S., Seguı', A.E., Cabrelles, M., 2014. Range-based versus automated markerless imagebased techniques for rock art documentation. The Photogrammetric Record 29 (145), 30-48.

Leroi-Gourhan, A., 1984. Arte y Grafismo en la Europa Prehisto' rica. Itsmo, Madrid.

Lorblanchet, M., 1984. Grotte du Pech-Merle. In: L'art des cavernes. Ministe` re de la Culture, Paris 467-474. 
Lorblanchet, M., 1989. From man, to animal and sign in Palaeolithic rock art. In: Morphy, F. (Ed.), Animals into Art. One World Archaeology Series 7. Unwin Hyman, London, pp. 109-143.

Macintosh, N.G.W., 1977. Beswick Creek Cave two decades later: a reappraisal. In: Ucko, P.J. (Ed.), Form in Indigenous Art.

Australian Institute of Aboriginal Studies, Canberra, pp. 191-197.

Meine, C.D., Archibald, G.W. (Eds.), 1996. The Cranes: Status Survey and Conservation Action Plan. IUCN, Switzerland and Cambridge.

Nicolau-Guillaumet, P., 2008. Avifaune et art pale' olithique. Essai pour une bibliographie exhaustive. Alauda 76 (4), 287-298. Peterson, R., Mountfort, G., Hollom, P.A.D., 1967. Gu1'a de Campo de las aves de España y dema's par'ses de Europa. Omega, Barcelona.

Piette, E., 1907. L'art pendant l'A`ge du Renne. Masson, Paris.

Ripoll, E., 1965. Una pintura de tipo paleolı'tico en la Sierra del Montsia '(Tarragona) y su possible relacio' n con los ori'genes del arte levantino. In Miscela' nea en Homenaje al Abate Henri Breuil. Museu Arqueologia de Catalunya, Barcelona, p. 297-305.

Sieveking, A., 1979. The Cave Artists. Thames and Hudson, London.

Simonnet, G., 1947. Une nouvelle plaquette de pierre grave' e magdale' nienne de la grande Grotte de Labastide, commune de Labastide (Hautes-Pyre' ne' es). Bulletin de la Socie' te' Pre' historique de Franc, aise 44 (1-2), 55-64.

Vilaseca, S., 1934. L'Estacio' -taller de si'lex de Sant Gregori. Memoria de la Academia de Ciencias y Artes de Barcelona 23 (21), 415-439.

Villaverde, V., 1994a. Arte Paleoli'tico de la Cova del Parpallo' . S.I.P., Diputacio' de Vale` ncia, Vale` ncia. Villaverde, V., 1994b. Arte mueble de la España Mediterra' nea: breve si'ntesis y algunas consideraciones teo ' ricas. Complutum 5, 139-162.

Villaverde, V., Martı'nez, R., Guillem, P.M., Lo' pez, E., Domingo, I., 2012. What do we mean by Levantine rock art? In: Garc1'a, J.J., Collado, H., Nash, G. (Eds.), The Levantine Question. Archaeolingua, Budapest, pp. $81-115$.

Viñas, R., Rubio, A., Ruiz, J.F., 2010. La te' cnica paleolı'tica del trazo fino y estriado entre los orı genes del estilo levantino de la Peni'nsula Ibe' rica. Evidencias para una reflexion. In: Clottes, J. (Ed.), L'art pre' historique dans le monde.In: Actes du Congre`s IFRAO, Tarascon-sur-Arie` ge, 2010. 
Mots cle's :

Art Pale' olithique Art mobilier

Magdale' nien supe' rieur final Grue

Figures anthropomorphes Sce`nes

\section{R E' S U M E'}

Cette e' tude pre' sente la de'couverte d'un nouvel exemple d'art mobilier dans le nord-est de la Pe 'ninsule Ibe' rique qui remonte au Pale'olithique supe'rieur final (12,250 T 60 BP). La pie'ce est examine' e dans le contexte de l'art pale' olithique europe' en pour de' terminer son importance et sa contribution a' notre compre' hension des pratiques artistiques pale' olithiques. Les motifs repre' sente's (oiseaux et humains) et les sche' mas de composition (une sce' ne narrative) sont, dans les deux cas, rares dans les ensembles pale'olithiques. En outre, cette nouvelle de'couverte contribue a' combler un vide ge' ographique dans le registre artistique car les e' vidences mate'rielles de l'art pale' olithique sont rares en Catalogne. Les caracte'ristiques anatomiques d'un des oiseaux sugge`rent qu'il s'agit d'une grue, une espe 'ce qui a e' te' repre' sente'e dans un nombre limite' de sites, comme cet article le synthe' tise. En outre, il n'y a que trois exemples connus d'oiseaux et d'humains en interaction dans une sce'ne narrative dans l'art pale 'olithique. Exposant des innovations dans le support graphique, les the' matiques et les normes de composition, cette nouvelle de'couverte a le potentiel de changer la de' finition classique de l'art pale' olithique europe'en et d'inte'grer la re'gion dans les tendances artistiques circulant en Ibe'rie me' diterra- ne 'enne pendant le Magdale' nien Supe' rieur. 
Social Sciences: Achievements and Prospects Journal 4(12), 2019

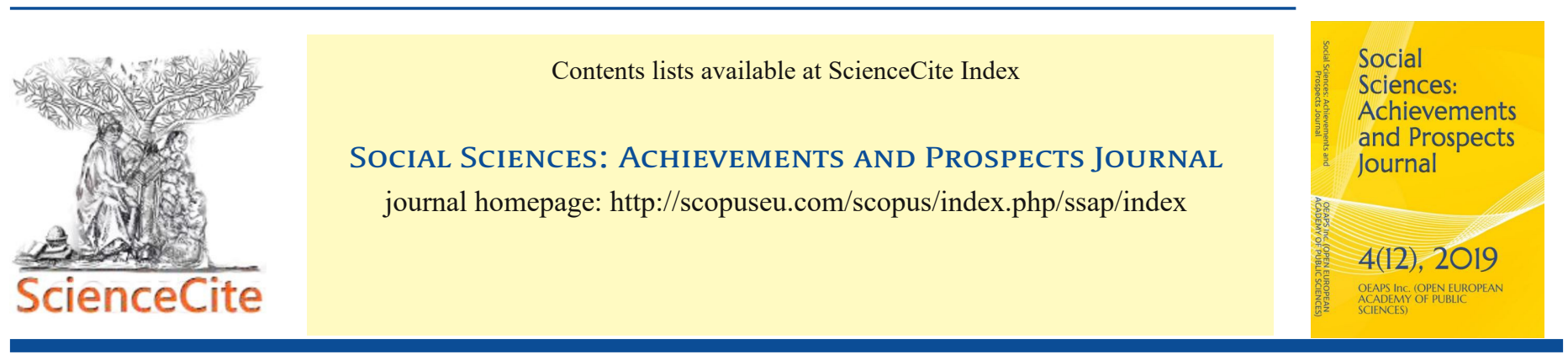

\section{The Importance of Dynamics and Writing Practical Knowledge in the Study of Ancient Khorezm History}

\section{Qodirov Jakhongir}

Student, Departament of History, History faculty, Urgench State University, Urgench, Uzbekistan

\begin{tabular}{|c|c|c|}
\hline ARTICLE INF & & ABSTRACT \\
\hline Article history: & & A number of documents from Khorezm state registers economic \\
\hline Received & 04 May 2019 & calculations of palaces and dormitories, and various products sold to \\
\hline Accepted & 16 May 2019 & the treasury. The Koykhirilgankal'a inscriptions contain personal \\
\hline Available online & 16 May 2019 & names and 'aspubat', that is, a horseman, a horse-rider. \\
\hline
\end{tabular}

\section{Keywords:}

M.V.Vorobeva, M.M.Rojanskaya,

Koykredgal'a, al-Beruniy,

Akhadarya,

Great Oyobuyirqal,

Koykirtqal,

Kalaliqir 2,

Govur 3, A

yozqal,

Tuprakqal,

Khumbuztepa,

Yakuparsan,

Tukkala and Mizdahkan

(c) 2019 The Author. Published by OEAPS Inc. This is an open access article under the CC BY-NC-ND license (http://creativecommons.org/licenses/by-nc-nd/4.0/).

* Corresponding author. E-mail address: maqola_01@mail.ru 
Introduction

The study of the role of knowledge in the development of society is distinguished by its relevance to the various research studies. From the history of primitive society, the ecological knowledge of the environment and the environment surrounding the society has come from generation to generation through the methods of production and business practices of the labor force, the use of natural resources.

The importance of studying this subject is that it is the basis for the development of spiritual culture by striving to know man, understanding and evaluating phenomena, shaping his world outlook.

Therefore, the emergence and expansion of knowledge and practical skills in the Khorezm oasis, their expansion and application in various fields, from the development of plant and animal world, from natural nutrition to inventions of later periods and to new farming based on technological advancement (livestock as well as the emergence of a certain stage of civilization, it is important to recognize the relevance of the essence and significance of the creation of science, art, writing, and spiritual monuments.

In the case of ancient Khorezm, the dynamics of practical knowledge, the process of enlargement, and archeological data are reflected in the following fields of activity and events:

- housing construction, architecture and construction methods;

- work tools, tools and equipment for ceramic dishes;

- artificial irrigation - irrigation constructions, farming;

- artistic monuments, sculpture and painting;

surrounding environment, the study of natural conditions, the universe and events, and the observation of the movements of the celestial bodies.

On the basis of archaeological findings, it is possible to make comparative conclusions on the subject, but its urgency requires studying the development of practical knowledge and scientific bases in the Khorezm oasis up to Islam. This requirement is determined by the inadequacy of the problem.

There is not much research on the subject. Based on the findings of M.V.Vorobeva and M.M.Rojanskaya, Koykredgal's materials, and al-Beruniy, they analyzed the problem of the emergence of astronomy in Khorezm. Also in the findings of M.V.Vorobeva and M.S Lapirov-Skoblo, the geometric correlation of the architectural plans is considered. K.Abdrimov, G.K.Masharipova discovered some aspects of geometry, mathematics and astronomy development.

These studies are linked to the creation of a system of exact sciences in the ancient history of the Khorezm oasis, but the roots of the formation and development of practical knowledge in the case of Khorezm have not been considered.

These studies are linked to the creation of a system of exact sciences in the ancient history of the Khorezm oasis, but the roots of the formation and development of practical knowledge in the case of Khorezm have not been considered. 
Archaeological materials - residues, stoneware and ceramic dishes - related to the history of Khorezm's primitive society (the culture of the Neolithic Caltamine culture) have provided a limited coverage of this issue. By comparing existing archaeological sources with historical ethnographic data, there are some points of view and general conclusions.

In the IV-III millennium BC, the Khorezm oasis of Neolithic fishermen and hunters are located in the ancient river of Akhadarya in the right bank of the Amudarya River. It is not difficult to imagine how a person lived around the lake and surrounding sand dunes surrounded by numerous swamps, bushes, and reeds.

It was vital that the people living in such conditions have a certain knowledge of their natural properties and wealth. Ancient hunters and fishermen had to have a great deal of information about the fields they live in, the source of living, the natural environment, the useful and harmful plants, the characteristics of the animal world, the building materials and the rock needed to build weapons. The knowledge of space and distance measurements and timing has been formed due to the construction of houses, the need for weapons and ceramic dishes, daily exercises, requirements for hunting and fishery farming and other reasons.

Materials and Methods

With the change of economic forms and material culture of communities, the sphere of knowledge has expanded. Developed by these processes, the emergence of new ones has led to technological advances, and the world of beliefs and art has developed.

In the middle of the II millennium BC, the farming economy developed in the Khorezm oasis, and the irrigation system and the irrigation system were gradually improved. Researchers argue that the origin of astronomy in ancient times was closely linked to dehkans- ing, since the beginning and ending of crop production is directly related to the exchange of seasons. Therefore, it was necessary to observe the movements of the sun and the stars in ancient agrarian soci- ety, as it was possible to predict the seasonal regular recurrence of natural phenomena by observing the cyclical movements of celestial bodies.

Moreover, in ancient times, the religious beliefs of the earth and the celestial bodies revealed the creation of heavenly myths. When there is no record, they should be stated in the word (storytelling).

In addition to Beruniy's written sources, written sources of ancient Khorezm's astronomy have not yet reached us. Therefore, archaeological data serve as an important source in studying this problem.

At the time, S. Tolstov asserted that the central building of the fortified fortress, which consists of two floors, was not an observer. According to M.V.Vorobeva and M.M.Rojanskaya, the construction of Kukkyrgangala has been made possible by the use of the special calculations by the ancient builders for the use of astronomical observations. Also, found clay disks and circles. They have curves and triangular marks. In the Middle Ages, similar astronomical measurements have been widely used, which are called "astrology." At first glance it was possible to carry out special measurements and calculations using such a simple tool. 
Beruniy writes that the Khorezm people "employed moon locations and issued judgments on them (astrology). In their languages, names of addresses are kept in mind. There are no those who know the location of the addresses and their observation, and there is no one left to prove it. The astrologer in Horezm means "Searcher".

The explanation for this is "looking at moon locations." Khorezmians knew the archives better than Arabs. " According to Beruniy, astronomy was called the Aramaic language in the Horezmian language, and the level of development of Khorezm astronomers was higher than in Arabic until Islam.

According to Abu Rayhon Beruni, ancient khostats used the year based on the solar calendar, and this calendar dates back to the beginning of the 1st millennium BC. "The inhabitants of Khorezm are year-old and the beginning of the month are in accordance with the Sogdian people, and the Iranians are opposed ... The images of the Horezmian people resemble that of Sogdians," Beruniy writes.

The calendar used in the ancient Khorezm can be built on the calendar of the Zoroastrian calendar, such as the Swan calendar. The Khorezm calendar was 365 days a year, with a yearly 12 months of 30 days each.

Beruni's works include the following months: Navruzji, Ardvast, Horvdod, Jiri, Himodod, Axshrivriy, Avmriy, Yonoxn, Arv, Rimjd, Arshmn, Isfandaraji.

The scholar lists the dates and dates that are not affiliated with the Horezmian religions:

Navruz is the first day of Navruz, the new day.

Arijosuvon. It was the day when the weather would be very hot, its translation would mean "out of the clothes", "naked and opening hours". During the Beruni period, it was time to sprinkle with the sesame seeds and seeds that were sprinkled together.

Agiater (Berry and Fever), Beruniy writes that it was a time when it would be necessary to heat up in the autumn due to weather changes.

Figbrix - "the time of the king". Because of the cold of that day, Khorazmshah went to the edge of the city and walked there.

Namib - translation of it means "Night of the Night", Beethney says that Mina was a woman from the Khorezmian "kings and nobles, who came out of the palace at night with drunk silk dresses. It was spring. He has fallen out of the castle. When his sleepy night fell, he was struck by the cold night. People are surprised at how cold a person has died on the night of spring, and this phenomenon has turned into a wonderful, extraordinary story. " On the same day, the cabin uses vaporizers and ammonia, and the jinn and ghosts dig up their poison to cook.

Wahsh Aghom - Wahsh, the name of the angel who was delegated to the waters of Jayhun.

In short, in the early stages of this topic, people sought to learn about the causes of day and night, and the seasons, because of their efforts to acquire knowledge and skills in ancient Khorezm. In the course of historical development, they sought to link the celestial events with natural phenomena. Thus, the science of astronomy in Khorezm came to an end. In the life of an old farmer, he has a great deal of importance in cultivating crops, planting, welding, and harvesting. 
It is possible to observe the use of advanced building techniques (such as selection, defense system structure, bushings, shades, gates, architectural plans, housekeeping rooms, light holes, etc.) on the example of cities, synagogues.

The ancient Khorezm is one of the earliest places in Central Asia, and it is impossible to imagine the spiritual development of the region's inhabitants as one of the most valuable values of civilization. The letters of Khorezm were found in the Great Oyobuyirqal, Koykirtqal, Kalaliqir 2, Govur 3, Ayozqal, Tuprakqal, Khumbuztepa, Yakuparsan, Tukkala and Mizdahkan monuments. The oldest of them is miles. avv V-IV centuries; IV-II BC, III-IV and VII-VIII centuries. Khorezm inscription is also available in coins.

\section{Result and Discussion}

Khorezm inscriptions Tolstov, A.A. Freyman, V.B. Xen, V.A. Livshits, M.J. Drezden, X. Humbax, B.I. Waynberg and M. Ishakova's research is dedicated.

The development of the ancient alphabetic system in the Khorezm oasis, the expression of words and concepts in letters required a philological knowledge. It is well known that the schools were established as a result of writing in the ancient East. Reading and reading skills and knowledge in schools. The palace and synagogue services were prepared by economic and administrative records (scribes). In Khorezm, it could be assumed that there were basics in the palaces and temples, and they would be forgotten if they were not.

Records found at the Voha monument indicate that ancient Khorezm residents were educated. The records are made of ceramics, leather and wooden sheets. Valivshits wrote the record on the surface of the sand found in the Big Bear Lake as "11 mari 9x". Unit of Measurement Measurement - "Mari" is known in the parfait farm records in the Math. He specified the amount of wine that he had stored in bigger quantities. According to VV Leivshits, mil. avv on the border of the centuries, the "marari" reached 16.5-17 liters, the volume of which was found in Oybolyir-Kala about 200 liters.

The Koykhirilgankal'a inscriptions contain personal names and 'aspubat', that is, a horseman, a horse-rider.

In the Tuproqqal'a inscriptions dated to the third century $\mathrm{AD}$, the list of wine (wine) and flour was listed as a tax liability for the public stock. The flour is marked by the unit of "xin" (weight 5-6 kg). The amount of flour was 10-13-25 times the number of people, and even 200 "xin". The documents contain names of subcontractors (Xvas, Abs, Marchv, Rexyamak, Vakhvashpas, Oreshtak, Abgavarnar, Narsav) and the time when the tax was delivered "252 years". V.A. According to Livshits, tax officials are called "chief economists" and "administrators".

The Mizdahkon ossuary lists the deceased 's personal name and patronymic name, for example, "the son of Kashak, the son of Kashak, the son of Patvarak, the son of Hagik, the son of Afrugh" and the Mitra rozi from the same, appropriate ".

A number of documents from Khorezm state registers economic calculations of palaces and dormitories, and various products sold to the treasury. 
The records of the remains found in the Temple of Galilee (1 BCE centuries BC) testify to the preservation of gold and silver in the bottles, the place where the treasury was treasured and valued. Other records contain taxes and commodity taxes: "Rashandatakka Tax", "Vaxshdatakka tax", "all-paying taxes".

An important aspect of the analyzed issue is that the ancient Khorezm inscription not only allows the gradual study of the level of state development, accountability and courtesy, taxation, population registration and socioeconomic relationships, as well as the history of spiritual culture. Literature, which is a part of culture, also developed in ancient times and in the early Middle Ages. Originally written in the form of oral poetry, there was a written publication as a result of writing, but Beruni pointed out that the books of Khorezm were erased during the Arab invasion.

\section{Conclusion}

In this study, the factors and causes of changes in the periodic development of the spiritual culture in the Khorezm oasis, the mutual understanding of historical traditions and innovations, the dynamics of practical knowledge and the importance of writing were analyzed.

Changes in culture and development on a new basis can be attributed to the following periods:

- II millennium BC avv VIII century (Bronze Age), the current changes are determined by the emergence of livestock and farming, and also in news funeral ceremonies;

- The placement of indigenous populations, affected by ethnic processes, contributed to the radical change and radical change of material and spiritual culture until the second half of the VII-VI century (the first Iron Age);

- The second half of the 6th century - the 5th century (the Ahamon era, the Khorezm ancient Persian state), the expansion of political factors and external relations influenced the spirituality of the material;

- The IV century (the independent state of Khorezm), until the end of the fourth century AD, on the basis of harmony with traditions and innovations, the development of antiquity culture, some of the ethno-political processes (the arrival of the tribal tribes, the reign of the Sassanid rulers) did not change the essence of the spiritual essence.

\section{References:}

1. Андрианов Б.В. Народнне традиции природопользования и экологические кризисн//Приаралье в древности и средневековье. - М.: ИВЛ РАН, 1998. - С. 60.

2. Воробьева М.Г., Рожанская М.М. О некорнх астрономических функциях Кой-Крнлган-калн//КойКрнлган-кала - памятник культурн древнего Хорезма. IV в до н.э. - IV в н.э. Тр.ХАЭЭ. - М., 1967. Т. V. C. 251-268.

3. Воробьева М.Г. Дингильдже. Усадьба серединн Т тнсячелетия до н.э. в Древ- нем Хорезме//МХЭ. М., 1973. Вьш. 9. - С. 113-117; Лапиров-Скобло М.С. Анализ построения древним зодчим плана КойКрнлган-калн//Этнография и археология Средней Азии. - М.: Наука, 1979. — С. 58-65.

4. Абдримов К. Қадимги Хоразм илмий мактабининг бош астроархеологик мезонлари//ИМКУ. Самарқанд, 1999. - Б. 123-125; Машарипова Г.К. Хораз- млик алломаларнинг математика ва астрономия сохасидаги илмий изланишлари. - Т.: Фан, 2004. - Б. 7-24.

5. Толстов С.П. По древним дельтам Окса и Яксарта. - М.: Изд. вост. лит., 1962. - С. 31.

6.Воробьева М.Г., Рожанская М.М. О некоторнх астрономических функциях...С. 251-252. 
7. Жўраев М. Юлдузлар билан боғлиқ халқ қарашлари ва самовий афсоналар/ /Улуғбек академияси ва олий мактаб. — Т., 1994. - Б. 53-54.

8. Толстов С.П. По древним дельтам...С. 134.

9. Кўрсатилган асар. С. 264.

10.Воробьева М.Г., Рожанская М.М. О некоторнх...С. 256-258, примеч. 132-133.

11. Абу Райхон Беруний. Танланган асарлар. І том. - Б. 282.

12.Кўрсатилган асар. Б. 280.

13.Лившиц В.А. Хорезмийский календарь и эрн древнего Хорезма//Палестинский сборник. - Л., 1970.

Вьш. 21. - С. 166-167; Норқулов Н.К. Беруний ва Хоразм. - Т.: Фан, 1973. — Б. 16; Илёсов С. Хоразм эраси//Фан ва турмуш. - Т., 2006. № 1-3. - Б. 41-42.

14.Кўрсатилган асар. Б. 84.

15. Ўша асар. Б. 280-282.

16.Толстов С.П. По древним дельтам...С. 130, 215-218; Лившиц В.А. Хорезмийские надписи на оссуариях с некрополя Миздахкана...; Вайнберг Б.И. Поселения Гяур 3//Археологические открнтия 1980 г. - М.: Наука, 1981. — С. 465; Мамбетуллаев М. Городиоде Большая Айбуйир-кала...С. 100-101; Лившиц В.А., Мамбетуллаев М.М. Острак из Хумбуз-тепе...С. $34-45$.

17.Крамер С.Н. История начинается в Шумере/Пер. Ф.Л.Мендельсона. — М.: Наука, 1965. - С. 17-20.

18.Мамбетуллаев М.М. Городивде Большая Айбуйир-кала...С. 100.

19.Дьяконов И.М., Дьяконов М.М., Лившиц В.А. Документн из древней Нисн/ Материалн ЮТАКЭ. М. - Л., 1951. Внп. 2. - С. 24-65.

20.Толстов С.П. Надписи и знаки. Кой-Крнлган-кала - памятник культурн древнего Хорезма. IV в. до н.э. - IV в н.э.//Тр.ХАЭЭ. - М., Т. V. - С. 220-222.

21.Лившиц ВА Документн. Топрак-кала. Дворец//Tр.ХАЭЭ. - М., 1984. Т. XIV. - С. 256.

22.Лившиц В.А. Хорезмийские надписи на оссуариях с некрополя Миздахкана...С. 247-252.

23.Лившиц В.А. Надписи и документн//Калалигир 2...С. 188-189. 
Social Sciences: Achievements and Prospects Journal 4(12), 2019

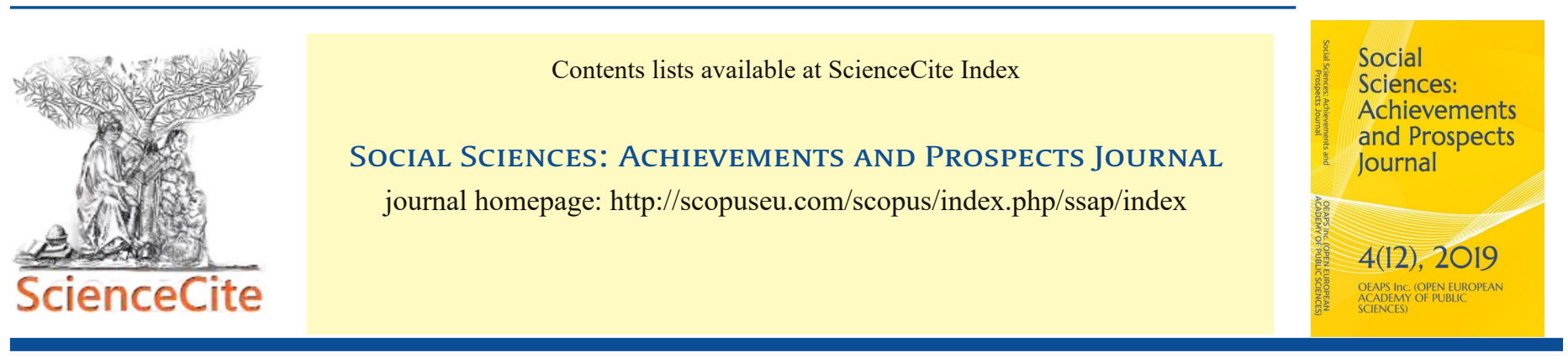

\title{
Amir Temur and religious legal issues
}

\author{
Artikov Khudayor ${ }^{1}$, Qodirov Jakhongir ${ }^{2}$ \\ ${ }^{1}$ Lecturer, Departament of History, History faculty, Urgench State University, Urgench, Uzbekistan \\ ${ }^{2}$ Student, Departament of History, History faculty, Urgench State University, Urgench, Uzbekistan
}

\begin{tabular}{|c|c|}
\hline ARTICLE INFO & ABSTRACT \\
\hline Article history: & Amir Temur's great achievements in statehood have been a significant \\
\hline 04 May 2019 & factor. Hughuk Jahongir, a great emperor, great scientist Amir Temur \\
\hline Accepted $\quad 16$ May 2019 & was a humble person. The Sahibkiran would gather the scholars of the \\
\hline Available online 16 May 2019 & place wherever he went, and hold a scientific meeting. He asked them \\
\hline $\begin{array}{l}\text { Keywords: } \\
\text { The Sahibkiran }\end{array}$ & $\begin{array}{l}\text { a variety of questions and tested the scientific level and discussed the } \\
\text { actual issues. }\end{array}$ \\
\hline
\end{tabular}

the Qur'an,

Temur's son,

Muslim,

Islamic Relations

(c) 2019 The Author. Published by OEAPS Inc. This is an open access article under the CC BY-NC-ND license (http://creativecommons.org/licenses/by-nc-nd/4.0/). 
Introduction

When Amir Temur's father was given to the primary school in the neighborhood, he was the youngest student. But, despite his youth, he was separated from the intellect and the sharp mind. He quickly absorbed the responsibilities given to him and gave answers to questions most frequently asked by the Masters. The Mudarrises were amazed at his mind and sharp mindset. They told her father, Temur's son, that he had the knowledge we had, and that he would give it to a better teacher than us. Amir Temur was a very young man, and he memorized the Quran in three years. He was fond of the book of Allah so much that he had not yet been able to experiment with Amir Temur. Amir Temur used to read every single sura from the beginning to the end, from the end to the end, and vice versa. This is a proof that the Sahibkiran is a good one, even if no one is encouraged. It is well-known that the memory of the ancient Muslims was consumed by the masses. Now, if he is the ruler of the state, it is possible to know how much the people will respect him.

Amir Temur not only memorized the Qur'an, but also understood its meanings, and sophisticated other sciences. He was famous for his figh knowledge. This, in turn, honors his reputation, and further enhanced the respect and respect of the people.

Most importantly, Amir Temur was a true Muslim, not in his words, but in reality. Although he himself possessed a strong Islamic aristocracy, others were also trying to prevent this deviation. Amir Temur is known to have criticized the famous poet Hafez Sherozi as saying that he was reading some of the Bithhas in the majority of the scholars and was haraam. This served to Amir Temur as a Muslim, as a scientist, as a king, as well as to serve as a king, to increase his love, respect, and obedience to the people.

\section{Materials and Methods}

As we have already said, Sahibkiran was a Muslim, not in his mouth. He was a Muslim, fully fulfilling religious propositions. Amir Temur is a scholar, and his brave enemies and critics admit that his religious demands are met in his own way. They said that they would not break their pledge if they were to perform Salat al-Qa'bi-kirqān in the time of Sahīqirân. Amir Temur did not violate the Shari'ah, even when he was described as the most prominent of his life. By following the rules of Islam, Amir Temur first fulfills his duty and fulfills the commandments that are obligatory for every servant of God, whether he is king or not. At the same time, these Islamic attributes would enhance their reputation among the people and strengthen their power. For example, let's take namaz. In the Muslim community, immoral officials have never been respected by the Muslim community. The same is true of fasting. A person who did not fast would not be able to attract Muslims.

Lying is not only for Muslims, but also for all other nations. Lying is always the quality that is bad in all places, in all places, and in all nations. This quality has dropped its reputation as a king, gado. Particularly disadvantaged by the lies and reputation of the people in the country. The quality of deception is especially harsh in the Muslims. Among the Muslims, the word "liar is an enemy of God" has always been the case. Lying is repeatedly criticized by the Word of God, which has been abused by the Amir al-Mu'mineen. It is a stain on our Prophet. Therefore, Amir Temur did not lie as a Muslim person. It strengthened his admiration of the friend and enemy by raising his reputation as a result of helping him avoid sin. 
Harmful drinking and dirty walking, that is, adultery, are all condemned on all sides. In fact, it has been harshly condemned by the rulers in these matters, even among the nations that have not been forbidden. That is why the reputation of those who do these things has been severed. It is well-known and famous that Islam has strictly prohibited these two acts of Islam. From this point of view, it has been viewed from the point of view of insulting the wine-makers and adulterers. They treated them as reprehensible, not reputed. Not to honor the covenant has never been reputed to anyone. This bad quality is strongly condemned especially among Muslims. This is the ruling of the Koran, the Sunnah of the Prophet (peace and blessings of Allah be upon him). Of course, drinking unclean liquor, not going dirty and committing to the covenant would greatly enhance Amir Temur's reputation before his citizens. We have discussed some of the Islamic characteristics of the Sahibkiran, many of which have been recognized by historians. This, like others, shows that good deeds in Amir Temur are due to his religion of Islam. It was Amir Temur's innocence, and his personality was only competent qualities. However, we are reminded of the attributes of the Blessed Prophet's -upon him blessings and peace- words: "Remember the good qualities of those who have passed away". At the same time, we would like to underline that these qualities are a key factor in the success of the Sahibkiran judgment. We all know that personal qualities are influential in everything.

Amir Temur and his Islamic Relations in the Society Amir Temur has not regarded Islam as a hidden link between God and the person. Perhaps he was well aware that Islam should be superior to anything in social relations. Therefore, he urged his relatives and citizens to continually study Islam and to adhere to it. In this sense, Amir Temur was a khashu-khalifa. Historians acknowledge that the Sahibkiran's children and loved ones need to study the religion of Islam and to live by it. He also called on his officials, soldiers and citizens to do so. Consider one example. One day, snowfall in the wilderness will be snowing. Exercise must be stopped. Then Amir Temur collects his people in the tent and declares that he will receive some gold prize if he finds a verse about the Quran. People spread tents and spend hours reading the Qur'an. Then, Sakhibkiron will recapture them and criticize the ignorance of the Qur'an. The Qur'ân al-kerîm reminds us that they are ignorant of the fact that there is no verse about the snow, because it is revealed in a warm, snowy land. He invites them to the Holy Koran and to Islam, and responds to various religious questions.

Speaking about Amir Temur's Islamic connection in society, we must point out the attitude of Islam towards the church and the Friday prayers that have been established for the development of these ties. Sahibqiron was always trying to avoid the public prayer. For the same reason, he always carried a mosque in his own walks. Wherever they go, the special people immediately set up a mosque and all pray together with the community under the leadership of Amir Temur. During his journey, Sohbqiran calls the adhan to perform namaz when he is walking with Hussain bin Isaak, the head of the town, to visit the town of Bishrheheh. Husain ibn Ishaq went to the mosque and asked permission to come to the mosque. Amir Temur went with me to pray with the church.

Take another place on Friday. When the Friday Prayer approached, the Sahibkiran, who felt that the people were not visible, came to his surprise and ordered him to bring his religious message. They bring a man dressed in slippers. Amir Temur asks him what religion to follow. He replied that he was Muslim. Amir Temur asks, "Are you praying?" He says, "Okay, okay?" Amir Temur says, "Today is Friday, but no one sees it, do not you perform Jumuah prayer?" The man answers, "Everyone can read in his own home." When the Sahib- 
kyrghir understands what the matter is, it is much more difficult to blame the person for making ablution with the religion. Allah tells the Jumu'ah prayer to recite the jamâ'at, reads and explains the Qur'ân al-karîm about it and prays the adhan and recites the Friday prayer to people. Certainly, such works and savings would add to the Sultan's reputation, respect for the Sultan, and to win the trust of the Muslim nation.

The major part of Amir Temur's relationship with society and citizens would be through scholars. He was highly respected by the scholars. If he had a name, he would have been proud of himself. It was not necessary for the ruler to be the scholars of the sect of the Sunnah and the Community. The Shiite and the Rifizist Madhhabs deserved to be regarded as even Christian or other religious scholars.

It is well-known that he was the guest of the Sultan of the Sultans, who invited the chief priest of the Sacred Christianity to his presence, and that the Blasphemer had spoken to him harshly, as well as among many. Amir Temur did not care about the visit of the scholars, but gave them generous gifts and gifts. Wherever he went, he would visit his grave, even if the famous and famous scholars had died. Another manifestation of the respect of the scholars by Sahibkiran was that he would not touch them when they entered the home of the scholars living in the battlefield. Amir Temur used to read and analyze books of his time as a scientist. This is the place where the scholars who read the book were alive, even if they were dead. Sheikh Muhammad Shabestani's book for a while, even though he was guilty, did not touch his countrymen or demolish his country. He also read Sahibkiran Firdavs's "Kohna". He visited the tomb that had been left unattended in his country.

\section{Result and Discussion}

This great relationship between the Amir Temur and the scholars of the Great Jahangir, because he was a scientist, was not merely a jeweler of merit, but his merit. The reputation of the scholars within the Muslim community is known to all. Even though ordinary Muslims abstain from everything, they respect the scholars. They always deal with their fatwas and words. In this sense, it is easy for the governor to gain the respect of the people who have gained the attention of the scholars. Amir Temur used this factor effectively.

The Sahibkiran would gather the scholars of the place wherever he went, and hold a scientific meeting. He asked them a variety of questions and tested the scientific level and discussed the actual issues. At almost every meeting of the audience, Amir Temur's knowledge, intelligence, morality, and every place where the influence of the scholars had influenced Amir Temur's reputation and the love of the people there.

Great Jahangir, great emperor, great scientist Amir Temur was a humble person. He did, in the scientific debate, find a problem that he himself did not know, or if the idea was wrong, he would immediately accept the right path. When the adhan was being prayed at the place of Bishrâfîh at Khurasan, he saw a shopkeeper asking, "Why are you doing that?" He said, "O Amir, we are following Allah's revelation of Allaah (verse 31)." Sahibqiron will ask the person what the meaning of the verse is. The shoper tells the meaning of the verse and says that God says, "Take your adornment in every mosque," meaning that you read this prayer in a beautiful manner and we are replacing our clothes. " Amir Temur says that if I am a Quranic Qur'an, but not a faqih, then I would go to the camp and change my clothes. 
Conclusion

Amir Temur made a great meeting in Damascus, inviting famous scholars of that time. Among the prominent scholars of that time are Imoduddin Mubariy, Siroj Iskandari, Bakhouddin Halabi, Inb Khaldun, Nizamuddin Shami and Arabs. Amir Temur greeted the scholars at the beginning of the meeting and tested each of them with specific questions. Then he proposes to rewrite the main issue and rewrite the Quranic verses. Scholars decide that this is a matter of days, and they finally decide whether this order can be changed and that it will be transmitted to Amir Temur at the last meeting. Sahibqiron argues with the scholars in support of his idea. Then he was satisfied with the words of the scholars and returned to his opinion, and announced to the public that the order of the Koran was always in its proper state.

Such a course certainly contributed to the reputation of Amir Temur and his love for the Muslim community. Undoubtedly, the abovementioned things have been a major factor in the great achievements of Amir Temur in statehood.

References:

1. Ахмедов Б. Амир Темурни ёд этиб. - Тошкент, Ўзбекистон. 1996.

2. Ахмедов Б. Амир Темур хақида хикоялар. - Тошкент,1998.

3. Ахмедов Б. Сохибкирон Темур. - Тошкент, 1996.

4. Ахмедов Б. Тарихдан сабоқлар. - Тошкент, «Ўкитувчи», 1994. Б. 299-311.

5. Ахмедов Б. Ўзбекистон тарихи манбалари. - Тошкент, «Ўкитувчи», 2001. Б. 171-173.

6. Ахмедов Б.А., Муқминова Р.Т., Пугаченкова Г.А. Амир Темур. - Тошкент, 1994.

7. Мухаммаджонов А. Темур ва темурийлар салтанати. - Тошкент, 1994. 33-46 бетлар.

8. Соснин В., Мухаммад Очил. Амир Темур ғори ажойиботлари. - Тошкент, Чўлпон. 1992.

9. Темур тузуклари. - Тошкент, Ғ.Ғулом нашриёти. 1991. II нашр.

10. Файзиев Т. Темурийлар шажараси. - Тошкент, 1995. 
Social Sciences: Achievements and Prospects Journal 4(12), 2019

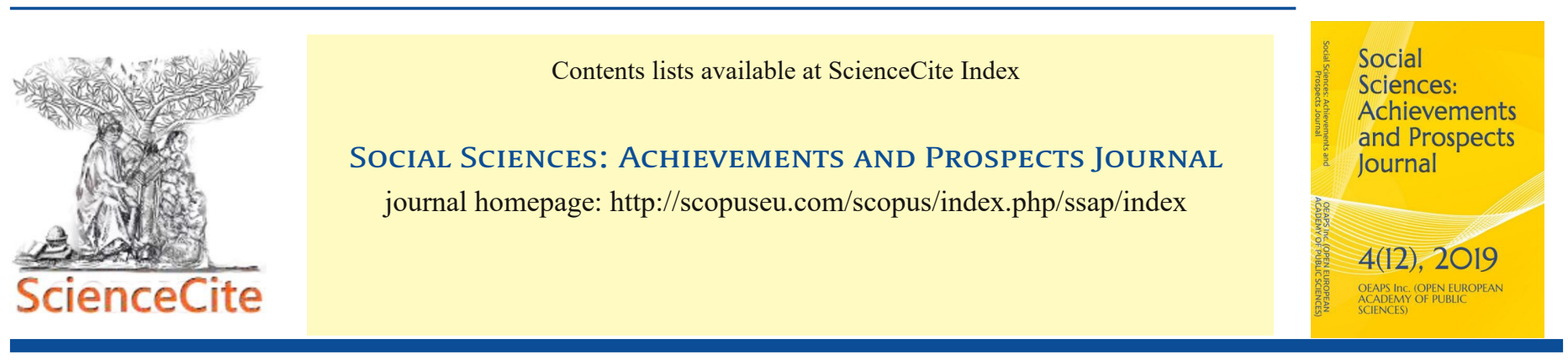

Temur's rules are the most important law in establishing

\section{a just and powerful state}

\section{Qodirov Jakhongir}

Student, Departament of History, History faculty, Urgench State University, Urgench, Uzbekistan

\begin{tabular}{|c|c|c|}
\hline ARTICLE INF & & ABSTRACT \\
\hline Article history: & & "Temur tuzuklari "- as an important rule of eracting a fair and a \\
\hline Received & 04 May 2019 & powerful government. "Amir temur build a government based on \\
\hline $\begin{array}{l}\text { Accepted } \\
\text { Available online }\end{array}$ & $\begin{array}{l}16 \text { May } 2019 \\
16 \text { May } 2019\end{array}$ & laws and traditions, who is a great strategist, skillful politician, \\
\hline
\end{tabular}

\section{Keywords:}

Shahjahon (1628-1657),

the ruler of Quqon,

Mukhammad Alikhan (1821-1842),

the emir of Bukhara Abdullakhan

(1885-1910) 
Introduction

There are exist a lot of historical compositions written in the period of Amir Temur and his generations.among them "Temur tuzuklari " plays an important role in compositions devoted to great ancestor's life and activity."Temur tuzuklari" Is an precious work taking place from famous libraries of the world.The composition which is famous with the names "Temur tuzuklari", "Malfuzoti temuriy","Voqeoti temuriy",being complect of rules written in XIV-XV century,in the period of Amir Temur was published in Turkish and in 1783 it was edited in English.First time this book was translated from farsi into uzbek in 1967.Complete version of book ,translated in farsi by X.Karamatov and A.Soguniy, was published in 1991. Socio-political position of Movarounnahr among 1345-1405, relations with neighborhood countries was narrated in this book.

Especially this book paid attention to the government administration .Main views of Amir Temur for society ,outlook for social lifestyle and the political and mental trendency of feudal powerful united government was expressed in "Temur tuzuklari "."Temur tuzuklari " is an pamphlet that signs the measure of modesty and the lifestyle of padishah.Most of the east rulers used from this book during their work and they appreciated it highly.For example ,Shahjahon (1628-1657), the ruler of Qo'qon,Mukhammad Alikhan (18211842), the emir of Bukhara Abdullakhan (1885-1910) made use of some pieces by copying from "Tuzukot" during their experiences. This book consists of two parts.IN the first part, Amir Temur's life and socio-political activity,from his seven years to his death, which he called the world famous fame, commander and prominent states-person,is that his capture of central government in Movarounnahr has ended with the eradication of feudal dissociation and centralized statehood, for example,Iran and Afganistan, the Golden Horde RULER Toktamishkhan ,against the sultan of turkia, Boyazid Yildrim who feared and terrified all over Europe and eventually made the great commander's campaigns to Azerbaijan,Georgia and india are briefly described.

Second part consists of advices told by Amir Temur and unique testaments which is dedicated to his heirs.It was told that relying on for whom to govern the country,to select a leaders, the salary of soldiers, order of governing the country, duties of leader ,emir,minister and other government officials' order how to esteem their jobs on the throne.

Materials and Methods

Amir Temur, differentiating from other older leaders, relies on not only one or more stratum, but also different social strata to govern the country .As mentioned "Temur tuzuklari", there exists 12 social category in society: 1)sayyidlar(generation of prophet)2)wise men 3) Muslim holy men;4)military men; 5)army;6)special confidential person;7)minister and secretary;8)astronomer, engineer and doctors;9)scientists of tafsir and hadis;10)artisan;11)sufiylar ;12) merchant and traveler.Padishah,treasure and soldier decided the fate of the country.Army was mainly divided into ten,hundred,thousand mens' part.The head of military unit which consists of ten person is called the leader of ten men and other s the leader of hundred men and thousand men and general.In book their rights, their salary were certainly shown.For example simple soldier took a salary which is equal the cost of horse that they rode. IN Temur tuzuklari,the soldiers were appointed the leader of ten men ,the leader of hundred men ,the leader of thousand men if they show off on fencing once, twice or three times .Emirs were encouraged showing off on fight and their work. 
Emir were given three privilege if they subdue a country with army.They are :1)the status of flag and kettledrum;2)the right of taking part in summit meeting 3)the leader of one region. The army which was organized by A.Temur was considered one of the most perfect and powerful army with their stategy and their skill at that time.IN "Temur tuzuklari" a lot of important information was given about the structure of the army,laking up arms and military service. The ability of army improved in the period of Babur and Husayn Baykara.

The military forces of Babur was a good example of occupying the tactics of Amir Temur.Amir Temur controlled his great sultanate by dividing portions.He gave Movarounnahr and other parts of country to his boys and grandsons. The head of parts looked like a ruler .They had their own army ,treasure and minister. However ,they solved important problems with their father and cental government.The head of parts must send one portion of tax to the treasure of central government and they had to go with their army to the central part of the country.

\section{Result and Discussion}

Amir Temur organized the structure of government diligently and tiny and he paid attention to the quality not the number.in the definition and implementionof state policy ,the principle of friendship of Nakshbandiya is based on the principle of "rosti -rusti".Sakhibkiran has developed this idea and is famous for its "power in justice" and has discovered a rule that has not been widely used in the experience of states .he made the governace of the state dependent on four factors:1)saltanat;2)khazina;3)kusin(in peoples'affairs)4)theology (black folk) the minister had to have four quality :1) originality and clean generation;2)intelligence;3)from the priesthood and the tribe of peace, the saints are governed 4)peacefulness and tolerance.Central state system headed by 7 minister.1)the minister of the country and the ruler (prime minister)2) the prime minister of sultanate of oman;3)minister of finance (land and property)4)minister of finance (minister for finance and economy);5)minister of justice affairs awareness of events)6) the minister of admiral;7)supervisions over relations with foreign countries. Amir Temur paid attention to advice,advice and advice. The council is a consultation on the issues of an impotant state with respect to the people .Mashvarat is the gathering of state.the Mashai,the fuzalo,the saqara and others."Although the work is secretly hidden behind the curtain",he said,"it is important to be aware of what'sgoing on and what is happening in the wake -the percent of state affairs",he said,and I decided to share it with a sword."Amir Temur built ' 12 chapters to take possession of the country and obey it.

1) The kingsmust be aware of every word that has been defined as being one word and being followed by the word.

2) It must be fair in every case and keep such people around.

3) Whatever work is to do ,let me judge.

4) If he chooses to work for a job ,he must be firm in his decision.

5) His decree is a duty for everybody.

6) So that he will not be able to convety his knowledge to anyone else.

7) let them consult together with others ,but take advantage of counsel.

8) if he hears good words in the affairs of sovereignty,race, and the affairs of the world, then let him come to a halt , in truth,with truth. 
9)let him be fierce and serious in the sight of the captain and the heedless,so that no one can dishonor him. 10) the ruler, the treasure,the army and the kingdom are under the rule of the king ,he must always remember it.

11) the ruler of the kingdom must be self-spared.

12) people shoukd be aware of and understand the council,often because they seek a fault and carry it out.

Conclusion

This country was a new state based on social strata and legally governed.He wrote the building of his kingdom and strengthened it on the basis of religious islam,law and order.I have done everything in the power of my kingdom .A fter his posthumous time , his followers also benifited from the art of managing art.Especially when Mirza Ulugbek was born. Amir Tmur was a wise ruler with a great statesman and devout spirituality.

Summarizing:in the 14th century ,the Amir Temur tried to unify the single economics space by deepening relations between the countries and regions .developing the integration,the Great Silk Road has begun the dialogue of cultures aming the countries that has passed.Amir Temur has created a unique school of public administration and governance and adhered to the rule of law in a just society.Developed on tactical and strategic basis,developing a state of the nation principle,based on its intellectual capabilities.the kingdom of Amir Temur was a mediocrity of spirituality and high culture.

\section{References:}

[1]. Sh.M .Mirziyayev."specch at he congress of the social movement of maternity youth/"xalq so'zi",year 2017, avgust 2

[2]. Culture and art in the Temurids' epoch.-tashkent,publication named after gafur gulam., 1996

[3]. Akhmedov.B. Amir Temur:tale and truth.-tashkent 
Social Sciences: Achievements and Prospects Journal 4(12), 2019

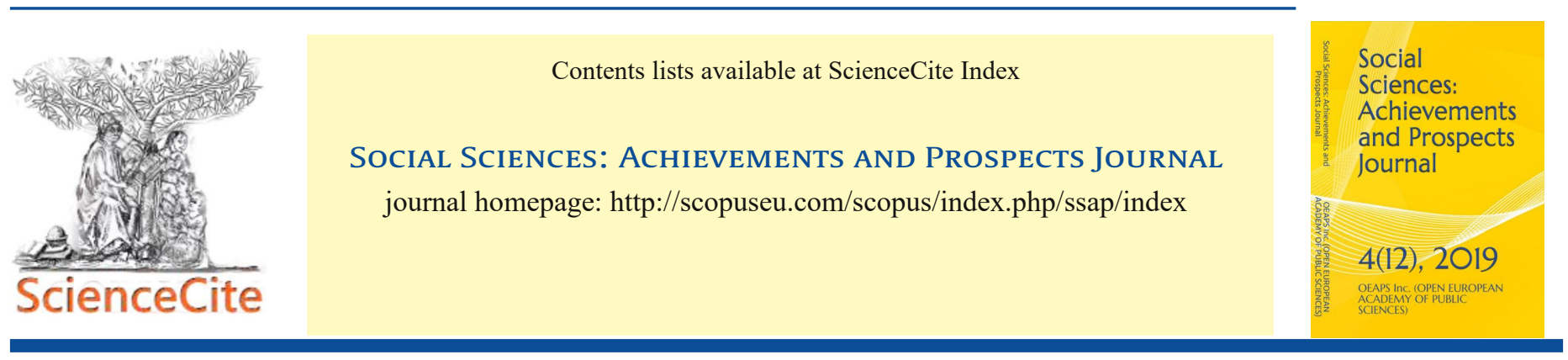

\section{Problems and solutions of increasing socio-political activeness of youth}

\section{Jafarkhan Isakhanov}

Student, Department of Social Sciences, Faculty of Psychology and Social Sciences, Samarkand State University, Samarkand, Uzbekistan

\begin{tabular}{ll}
\hline ARTICLE INFO \\
\hline Article history: & \\
Received & 08 May 2019 \\
Accepted & 14 May 2019 \\
Available online & 16 May 2019
\end{tabular}

\section{Keywords:}

socio-economic, radical reform, market economy, sociological systems, national idea, educational activities

\section{ABSTRACT}

This article discusses the importance of raising the socio-political activeness of young people, raising their legal and spiritual culture, and the upbringing of talented adults in the future. Nowadays, the study of the negative and positive aspects of globalization is one of the main challenges facing young people. The problem of forming a healthy generation in all respects is one of the pressing issues facing the state today. Because the development of any state is closely related to the younger generation, the foundation of the future. The issues of raising the socio-political activeness of the youth are important as a research object. 
From the first days of Independence, the Republic of Uzbekistan has supported the political activeness, legal literacy and active attitude of youth to social processes. As a system of ensuring the socialization of the youth of Uzbekistan, maintaining social stability and order in society, the study of law and the study of the process of understanding the right of young people are of great importance. After all, our country has accumulated a rich practical experience of working with them to ensure a bright future for the younger generation, where a legitimate and legal framework has been created. The direct participation of young people in the decisionmaking that affects their lives and their future during the period of rapid socio-economic changes is of great importance. In particular, another legal document developed on the initiative of the President of the Republic of Uzbekistan, Sh. Mirziyoyev that plays an important role in ensuring social activity of young people, the establishment of the "Development Strategy" on the five priority directions of development of the Republic of Uzbekistan in 2017-2021 has a special place. Each task set out in the development strategy intends to increase the social welfare of our people, achieve a radical reform of the quality of healthcare and education. In this regard, it is important to increase the social activeness of youth.[1]

In the process of globalization, the factors hindering the increase in the socio-political activeness of young people are manifold. As a result, today the concept of "Mass Culture" has appeared, affecting the formation of various extraneous elements in the worldview of the growing generation. Particularly, the widespread use of social networks among young people naturally provokes the need for a profound scientific research on this issue. The transition to market economy is a historical necessity, which dictates the high level of the spiritual life of society, the ideological, political, legal, cultural-spiritual, educational maturity of a person. Spiritual maturity of the nation is one of the most important factors in ensuring the transition to a market economy. [2]

The factors, which give an opportunity and hinder the increase in the level of socio-political activeness of youth, can be classified as follows.

1. The factors providing opportunities for increasing the level of socio-political activeness of youth:

- opportunities created by the state;

- active work of the mechanism of social partnership in the activities of family, neighborhood, educational institution, youth organizations;

- events initiated by youth organizations aimed at increasing the socio-political activeness of youth;

- measures aimed at increasing the economic activeness of youth.

Factors hindering the level of socio-political activeness of youth:

- the low level of legal culture of youth;

- the lack of attention and responsibility towards young people by parents and the public;

- the spread of various types of vices among youth (drug addiction, drinking, prostitution);

- the state of early marriage among young people;

- destructive ideas and aspiration to western culture.

In particular, there are features of social networks on the Internet that negatively affect young people. According to psychologists, teenage is a specific period in the physiological and social development of the individual, during which it is noted that if teenagers are addicted to aggressive performances, online games, it will have unpleasant consequences. Also, young people who do not take into account the fact that in the European global network there are malicious websites, as well as the possibility of falling under the influence 
of virtual fraud, are exposed to information that can harm their mental and even physical health.

Researchers from the IDC analytical company after finding out the opinions of 302 citizens from the US, Brazil and Russia between the ages 15 to 24 came to the conclusion that: all those that were surveyed, admitted that the global network is convenient, useful and safe. According to IDC analysts, young Americans, unlike Russians and Brazilians, consider communication via Internet as a normal phenomenon.

Additionally, according to the results of Spanish Child Protection Agency, 44\% of children who regularly use the Internet have been persecuted at least once and $11 \%$ of them several times. In addition, $14,5 \%$ of the young people who participated in the survey appointed a meeting with unfamiliar people through the Internet, $10 \%$ went to such meetings alone, $7 \%$ did not tell anyone anything about it. It was also reported that $38 \%$ of world's children constantly follow sites in the spirit of violence, $26 \%$ of children follow sites of a nationalist nature. Moreover, surveys conducted by UNICEF showed that $90 \%$ of children who use the Internet face immoral pictures and videos, while $60 \%$ purposefully looked for this type of information.

At present, the ideology of national independence and the role of national idea in educating young people as perfect people are incomparable. Of course, among all the creatures that God created, the most mature and miraculous is man... Man should always strive for perfection in order to make the Earth prosperous and bring it to a perfect state, the task assigned to him."'[3] Aiming the power by means of guiding young people to perfection at preventing the problems in society, manifests itself as what leads young people to spiritual perfection. Historical and cultural values and specific traditions passed from generation to generation have been preserved in Uzbekistan. In fact, this idea is of great importance in educating young people in the spirit of spiritual values and national self-awareness, and in the future, it will play an important role for young people to find their niche in society. Teaching young people to know their history and respect it is one of the most significant achievements. The experiences and views gained as a system of historical development of humanity is inherited from generation to generation.

The analysis and elimination of factors, which give an opportunity and hinder the increase of socio-political activeness of young people, is actual. At the same time, increasing the socio-political activeness of young people is the most important part of the youth policy in our country, the productive use of opportunities and conditions created for young people in the society plays a great role in the development of harmonious youth in the future. When the young people themselves get interested in changing their socio-political knowledge, the measures we are taking can give good result. Therefore, in socio-political education, we must first explain the important role of socio-political knowledge and laws in human life.

Socio-political education is an expression of permanent and purposeful activity of workers in state institutions, public organizations and labor communities in the realization of their subjective rights and obligations, social dignity in the development of legal knowledge, social activity and socio-political consciousness. Sociopolitical education should make a high revolutionary turn from the point of legal thinking in the system of modern education. Theoretical and practical issues of socio-political education in the conditions of the construction, renewal of a socio-political state cannot and should not be solved from the old point of view. 
Many theories developed in this area have not only lagged behind the processes that are going on, but also, are not able to reflect the real changes in public life. After all, "Socio-political education is a complex and multifaceted phenomenon; it is difficult to define it one-sided. Legal education is the influence of an organized, systematic, concrete goal on a person, which forms legal consciousness, legal guidelines, skills and habits of obedient behavior to the law."[4]

Lawyer and scientist O. Karimova defines socio-political education as follows, socio-political education is an action that is carried out regularly on an organizational basis, pursues a clear goal and is able to influence a person (group of people), creates in them the qualities of socio-political consciousness, socio-political knowledge, and observance of laws.[5]

Based on the general definitions provided above, if we define the concept of socio-political education of young people as this: it consists of socio-political education of young people - the socio-political knowledge of young future specialists, socio-political consciousness, educational activities of higher educational institutions aimed at analyzing social activity, subjective rights and obligations of youth, the understanding of socio-political, socio - humanitarian essence, as well as their initiatives and the issues of socio-political educational activity is understood.

The study of legal phenomena and concepts elevates the perception of young people about democratic and fair civil education, develops their socio-political thinking, their social activity, the important qualities that exist in every morally harmonious person.

At the same time, the analysis of the situation in the sphere and the measures carried out shows that the work on the issues affecting the broad range of young people, especially for the creation of suitable conditions for unorganized youth to find their place in life, provision of comprehensive support, vocational guidance and employment to them, promotion of their initiatives, do not meet the demands. The adoption of the law "The basis of state youth policy in the Republic of Uzbekistan", adopted for the purpose of radical improvement of activity in this sphere, in this regard, serves not only as a legal basis for the growth of the legal consciousness of young people, but also as a legal basis for the protection of their interests. State policy youth is a system of socio-economic, organizational and legal measures implemented by the state, which creates conditions for the social formation of young people and their development of potential in intellectual, creative and other spheres. [6]

In fact, this law has created favorable conditions for the organization and material provision of the implementation of state youth policy, updating the measures set for the youth and expanding the network of non-governmental structures conducting youth policy in accordance with the reform process, empowering their activities in the education of young people, ensuring the active participation of young people in the sociopolitical processes.

The law "On the basis of state youth policy in the Republic of Uzbekistan" stipulates " Direct participation of young people in the formation and implementation of policies and programs aimed atthe development of society, especially the life of young people of the Republic" [7]. In any democratic society, youth 
participation in socio-economic life requires comprehensive political knowledge, legal consciousness, a high level of responsibility.

From the point of view of the mood of young people in the country and how they are subjected to the processes of reform, the passion and interests of young people to find their place in society, two types of opposite situations and characteristics manifest themselves in the process of research:

- involvement in the processes of innovation and modernization, deep understanding of their essence, support for the goals and content of reforms, striving for a new relationship, research, striving to have their own social voice, confidence in themselves and in their perception, willingness to spend their potential for the development of society, striving for perfection as a personality, linking their development with the development of society, readiness for creative work, open-mindedness and pure volunteerism;

- indifference among young people, distrust of governing systems, the mood of idleness built on the basis of the fact that everything should be created for me by the state, the predisposition to foreign ideas, the tendency to conflict, the dissatisfaction of one's own social situation, the inability to work, the inability to believe in one's future, the inability to get out of conflicts, the creation of such situations, ignorant of laws, lack of knowledge, depression.

At the same time, there are also different attitudes and views among young people regarding education, labor, culture, obedience to the laws, understanding and acceptance of the new democratic principles, social and political consciousness, religion and the balance of a democratic society. The complexity and variety of this situation, especially its opposite sides shows the need to further promote the activities of propaganda among young people, to increase its influence on the public consciousness, while the responsibility of youth organizations is high.

Stemming from the above-mentioned, the following conclusions and theoretical generalizations, characteristic for the tasks of solving youth issues in the country can be made:

- to educate the youth on the qualities of their active participation in the processes of political and economic reforms, confidence in reforms, reliance on the immortality of democratic values in order to open the way and ensure their activities in the development of society;

- to achieve incentive-based use of the existing high-level and positive-oriented potential of young people on time, such as the pursuit of innovation, initiative, rapid adaptation to the market economy, support for new directions;

- to educate young people as pure, genuine, kind, to turn them into patriots of their motherland and family, to make patriotism the principle and criterion of life, to make caring for the sake of the country's development into civil virtue;

-to support the education of the healthy generation and to create all necessary opportunities, to add not only the elements of physical, internal mental, psychological, spiritual and ideological health to the concept of the healthy generation, but also building the health of young people on the basis of universal and national values;

- to accept the issue of youth policy and its implementation as one of the necessary components of national and state security, to promote that youth is the reserve wealth of the development of the state perspective;

- the broad integration of the principles of political consciousness and political thought among young people, the formation of skills of political culture in them, the creation and effective use of natural development 
systems for the promotion of young people's political consciousness and skills;

- to study the mood, interests and socio-political condition of young people and develop the activities of various sociological systems for scientific analysis, implementation of monitoring of socio-political and economic condition of young people.

Based on the above considerations, it is worthwhile to put forward the following proposals on increasing the socio-political activeness of young people:

- systematization of structures engaged in youth work;

- implementation of projects aimed at increasing the socio-political activeness of young people by creating a mechanism for involving an unorganized part of the population (migrant youth, etc.);

- establishing the activities of sociological centers dealing with youth problems in the regions.

\section{References:}

[1]. Decree of the President of the Republic of Uzbekistan "On the Development Strategy for further development of the Republic of Uzbekistan”, Tashkent, February 7, 2017

[2]. Rustamova M. Philosophical aspects of the formation of a culture of contemplation in young people. - T.: Mehnat, 2000.

[3]. Valikhojaev B. "Perfect Man - Perfect Society: In the interpretation of Alisher Navoi" / / "Ma'rifat" newspaper, January 23, 2002.

[4]. Tadjikhanov U, Saidov A. The Theory of Legal Culture T. 2.-T. The Republic Of Uzbekistan. IIV AKAD 1998 p. 195

[5]. Karimova. O. The Methodology of Legal Education. T. TSPU named after Nizami.- 2000.- p.5

[6]. Law of the Republic of Uzbekistan "On the state youth policy", Tashkent 2016., Article 3

[7]. Collection of laws and international treaties of the Republic of Uzbekistan, Tashkent: Sharq, 1995. - p.344 
Social Sciences: Achievements and Prospects Journal 4(12), 2019

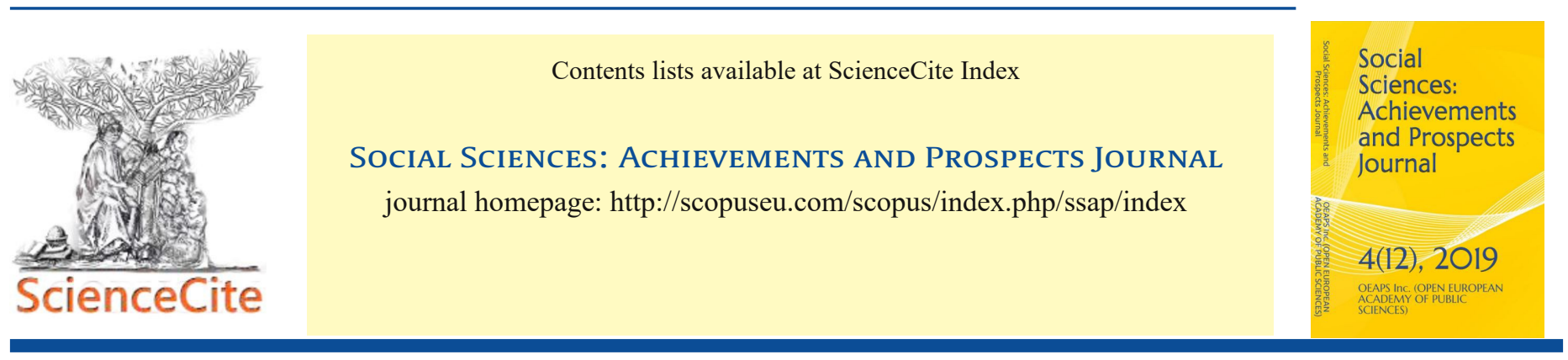

\section{Gender characteristic in the current}

\section{Matnazarov Shakhzodbek Baxtiyarovich}

Student, Department of Uzbek Linguistic, Faculty of Philology, Urgench State University, Urgench city, Uzbekistan

\section{ARTICLE INFO}

\section{Article history:}

Received

Accepted

Available online

\section{Keywords:}

linguistics, phonetic, lexical, phraseological, grammatical, stylistic, gender analysis, official communication

\section{ABSTRACT}

In the contemporary linguistics, there is a growing focus on sciencerelated gender linguistics related to the role that a person has in society, including their role in society and their linguistic characteristics. Gender linguistics plays a significant role in society. In the search for a guilty person, the inquiry officer will try to identify the person and the identity of the person who committed the crime first. Their records, signatures, actions and words shall be determined by the person who committed the crime. Gender linguistics serves as a major source for addressing these issues. 
Introduction

The men and women of one kind for many thousands of years have differed from one another in terms of their role in society, and these two sexes are different from the point of view of linguistics. In particular, there are significant differences in the use of linguistic and non-formal units and their access to the linguistic and nonlinguistic units. Many linguistic and non-formalities have gender identity as they belong to that gender.

As you know, oral discourse differs from gender to speech. When examining the structure of texts, the differences between phonetic, lexical, phraseological, grammatical, stylistic, and other types of speech of men and women are evident. The phonetic features also differ in men's and men's speech. Speaking in the Uzbek language in the speeches of phonemes, doubling consonants phonemes (ma-zz-za, esh-sh-shak, ), the phenomenon is very rare in men's speech.

The logic of women is very active, and the pause is shorter than men's speech. The lexemas used in the speech of women and men are also uniqueit is important. Men in the language update process are women The new lexemes for academic and professional men are quickly adopted by the public more active and more active in speech. Women are also on a daily basis using neologisms effectively, to try to avoid it in official communication. As a woman is a natural person, she also uses more attractive and colorful lexemes, words that express personal relationships, and more positive words in the process of conversation.

The subject of the conversation is somewhat subdued. Emotional states: Psycho-physiological processes such as surprise, joy, frustration, hatred, and grief can be observed in them. The speech of women and men in Uzbek language is also analyzed syntactically. The woman is trying to appeal to her partner's opinion and to avoid being hurt by the person who is talking to him or her, as long as she likes her. For example, later on, it would be better if we later go down, then let's go later, let's go later, let's go, maybe later.

The men then go in this situation later, and then the later, the later, and then the forms of expression. The culture of women and men has a unique character. Several studies have been conducted in the linguistic aspect of differentiating the characteristics of women, and in some societies, women's speeches have emerged as a separate study. This distinction is important and plays an important role in the culture of communication. The Uzbek linguistics has been published in recent years, but it is covered. In particular, S.Muminov, Sh. It is possible to see it in scientific researches of dancers. Sexual orientation of communication is of paramount importance, and sociology is one of the problems of studying.

Materials and Methods

Gender analysis of forms of appeal should be analyzed in the form of application forms for men and women, as well as reference forms for men and women. The expressions on the Uzbek language and its derivatives also have the same gender. Because in Uzbek the expressions are spoken by men or women in terms of the amount of use of speech. For example, most of these expressions are characterized by the use of men and women in speech processes, expressing their characteristic, impressive and figurative expression. There are such phrases and words that can be found in the speech, but they are only women specific, or vice versa, are specifically assigned to men's conversations. For example, the words used by men and women differ greatly from one another. 
In Uzbek, there are phrases that only apply to men's conversations. For example, many phrases, such as "Putting a nose on the ground", "Quivering out of the nape," "Do not crush," "Quit the abjag", "Strike the stars," are mainly used by men in speech is unique. In the speech of the women, the word "circle", "grunge", "stupid", "giggle", and phrases are specific, which are the lexical means expressing the positive sense of the word in different speech situations.

Also, according to the manuscript, women and men are used according to gender and men, expressions also vary from gender to viewpoint. You can scan. These contingencies were reflected in the application forms. Forms of appeal are again characterized by the fact that the speaker and the listener are clearly visible. It can be found in our normal culture of communication. "The women's speech has" aunt "," dugonajon "," master "and" dadasi "reference forms for their spouses." In the lexicon of historical work, mainly for women of the upper class, there are references to "begim", "lady", "great beggar", "high pseudonym". "Egachi" application form SH. Iskandarova's dissertation is considered as a reference to women. That is, the woman is used in the process of addressing.

This form of application can be seen in men's speech in the XIV-XV centuries as well as in opaquil. Basically, these forms of application, which are used in official conditions, are exchanged in terms of blood relations in informal speech, that is, when the members of the social group change their social roles, their speech changes accordingly.

Result and Discussion

These forms of application, which are not currently used in our current culture of communication, have been actively used by women in the historical era. "Holamullo" and "Hadrat Momo" are used in Samarkand and its surrounding regions in relation to an older woman listener. The term "kin" is used to refer to elderly female adults in Kashkadarya and Surkhandarya regions. The age-old social orientation of forms of communication forms the basis of the Uzbek culture of communication, as in the national mentality of the Uzbeks, there are such honor categories, which clearly demonstrate the age of communications.

This can be traced in all of the speech labels. The differences between age and gender can be found in the speeches. Therefore, the speeches made by the speeches, frazeologisms, The grammatical construction of the discourse gives certain information about it Hashimov's "The Lives of the Night" in the following text Here are the words of a man and a woman: "You're a fool!" Said the Commissar with a trumpet.

- How many times have I said: Bring your son-in-law to justice! Here is your math, and your daughter will give you a cat. It cuts half of its land. "One of my dear little girls has to stay in the yard with one of them," said Kurbonoy, hooligans. "All right," said he slowly. - I put it in God. The commissar laughed. Laughing beauty. He says, "xex-xex-xex", as if he were a man.

"God has no other choice than to you!" It looks as though I'm listening to my boyfriend. Kurbonoy married a married couple a simple remover of its own difficulties. It is odds he does not explicitly state his views on others The attitude is given in the art text as more inner speech. The writer has preserved genderspecific characteristics of women's speech through the internal monologue. 
The second participant of the dialogue, the Commissioner, was a young man who was influenced by the ideology of the sovereign, and throughout his lifetime protected the interests of this ideology. In her speech, skepticism of all, women's indifference, and cruelty. He does not take into account that the speaker is a woman, he uses words and phrases such as "stupid" and "pushed his legs back." This shows that he is an immoral, shameless, and civilized person.

Conclusion

There is an expression of insult in the expression of the speaker. It is evident that the difference between the language of speech and the grammar, the emotional-expressive, and the evaluation of women's and men's opinions are distinctly different. This is due to factors such as the social status of a man or woman in society, a way of life, attitude to reality, and linguistic background.

\section{References}

[1]. Абдуллаев А. Ўзбек тилида экспрессивлик ифодалашнинг синтактик усули. - Тошкент: Фан, 1987. -88 б.

[2]. Абдуллаева М., Абдурашидов М., Абилов У. Фалсафа қисқача изохли луғат. -Тошкент: 'Шарқ". -Б.126.

[3]. Абдурахмонов Х., Махмудов Н. Сўз эстетикаси. - Тошкент: Фан, 1981. -60 б.

[4]. Акбарова 3. Мурожаат шаклининг тасниф асослари // Ўзбек тили ва адабиёти, 74-76-б.

[5]. Алимасов В. Гендер фалсафаси. - Тошкент, 2008, 5 б. 
Contents lists available at ScienceCite Index

Social Sciences: Achievements and Prospects Journal journal homepage:http://scopuseu.com/scopus/index.php/ssap/ index 
MINISTERIO DE EDUCACIÓN, CULTURA Y DEPORTE

Subsecretaría

Subdirección General de Cooperación Internacional

Edita: @ SECRETARÍA GENERAL TÉCNICA

Subdirección General de Documentación y Publicaciones

Edición: 2019

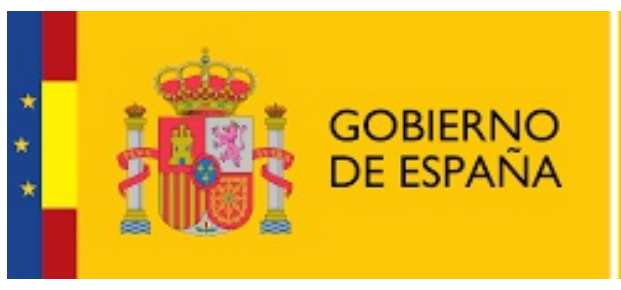

MINISTERIO

DE EDUCACIÓN, CULTURA

Y DEPORTE

Approved at the meeting of the editorial board Social Sciences: Achievements and Prospects Journal 4(12), 2019/ OEAPS Inc.(Open European Academy of Public Sciences); Chief Editor Mark Freeman Barcelona, Spain. 16.05.2019: OEAPS Inc., 2019. - 92 P.

Number layout 09.06.2019

Signed in print 10.06.2019

Published on 11.06.2019 